I NTER NATIONAL MONETARY FUND

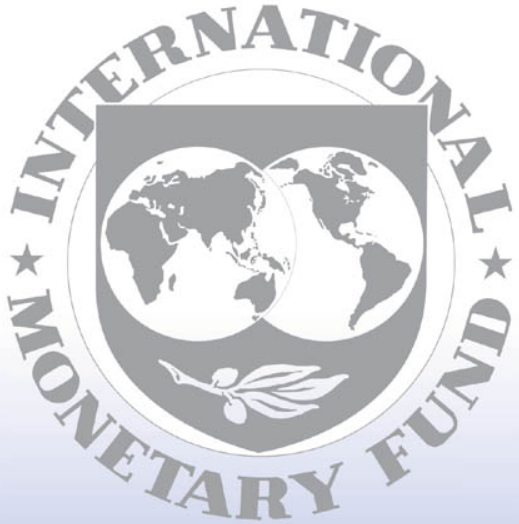

Staff

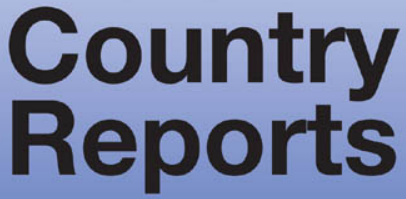




\section{Romania: First and Second Reviews Under the Stand-By Arrangement, Request for Waivers, and Modification of Performance Criterion-Staff Report; Staff Statement; News Brief on the Executive Board Discussion; and Statement by the Executive Director for Romania}

In the context of the first and second reviews under the Stand-By Arrangement, Request for Waivers, and Modification of Performance Criterion with Romania, the following documents have been released and are included in this package:

- the staff report for the first and second reviews under the Stand-By Arrangement, Request for Waivers, and Modification of Perfornance Criterion, prepared by a staff team of the IMF, following discussions that ended on July 17, 2002 with the officials of Romania on economic developments and policies. Based on information available at the time of these discussions, the staff report was completed on August 13, 2002. The views expressed in the staff report are those of the staff team and do not necessarily reflect the views of the Executive Board of the IMF.

- a staff statement of August 28, 2002 updating information on recent developments.

- a News Brief sumtnarizing the views of the Executive Board as expressed during its August 28, 2002 discussion of the staff report that completed the review.

- a statement by the Executive Director for Romania.

The documents listed below have been or will be separately released:

Letter of Intent by the authorities of Romania*

Supplementary Memorandum on Economic and Financial Policies by the authorities of Romania*

Technical Memorandum of Understanding*

* May also be included in Staff Report.

The policy of publication of staff reports and other documents by the IMF allows for the deletion of market-sensitive information.

To assist the IMF in evaluating the publication policy, reader comments are invited and may be sent by e-mail to Publicationpolicy@imf.org.

Copies of this report are available to the public from International Monetary Fund * Publication Services

70019 th Street, N.W. - Washington, D.C. 20431

Telephone: (202) 6237430 - Telefax: (202) 6237201

E-mail: publications@imf.org • Internet: http//www.imf.org

Price: $\$ 15.00$ a copy

International Monetary Fund

Washington, D.C. 
INTERNATIONAL MONETARY FUND

ROMANIA

First and Second Reviews Under the Stand-By Arrangement, Request for Waivers, and Modification of Performance Criterion

Prepared by the European I and

the Policy Development and Review Departments

(In consultation with other departments)

Approved by Michael Deppler and Liam P. Ebrill

August 13, 2002

Contents

Page

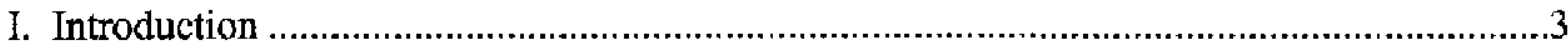

II. Recent Economic Developments and Performance Under the Program...............................5

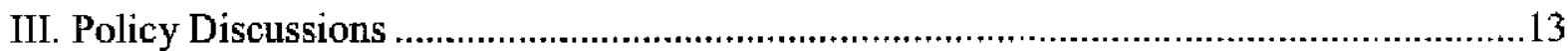

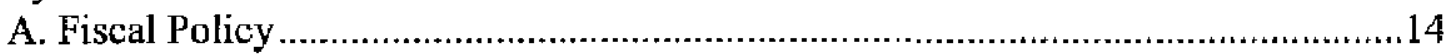

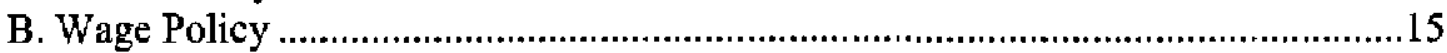

C. Energy Sector Reforms .................................................................................16

D. Monetary Policy and Banking Reform …...........................................................17

E. Privatization....................................................................................................18

IV. Medium-Term Outlook, External Vulnerability, and Capacity to Repay the Fund ..........18

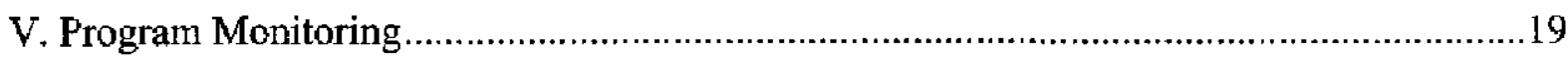

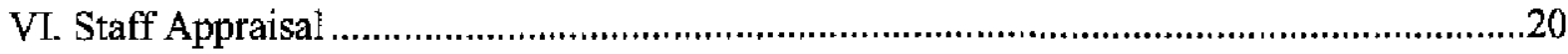

Text Boxes

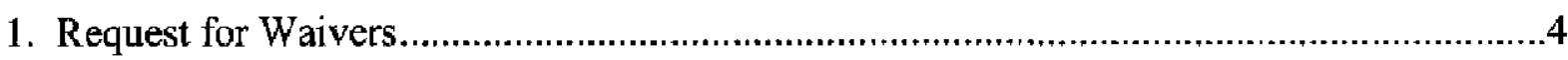

2. Structural Conditionality ..................................................................................19

Text Tables

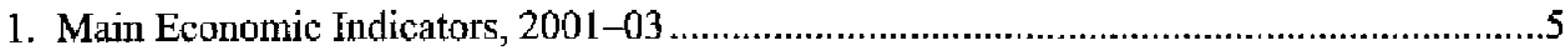

2. Export Performance of Romania and Neighboring Countries (2000-01) ...........................6

CInternational Monetary Fund. Not for Redistribution 
Figures

1. Consumer Price Index (CPI) and Net Wages, 2000-02

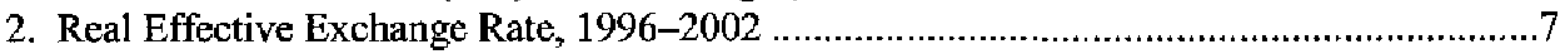

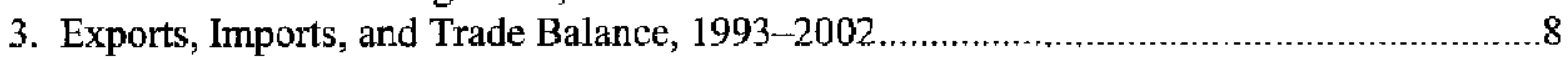

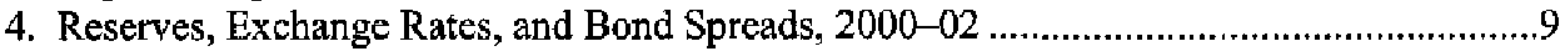

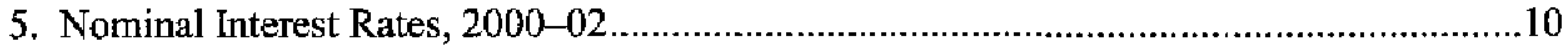

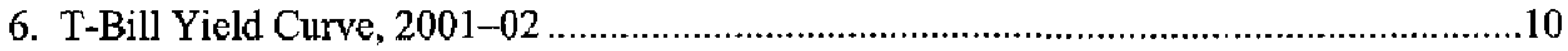

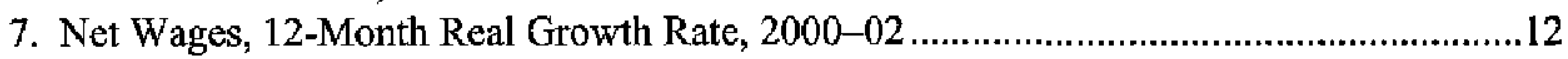

Tables

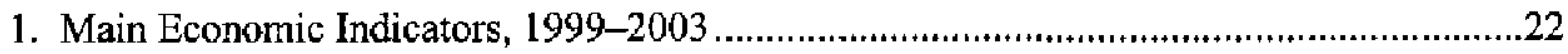

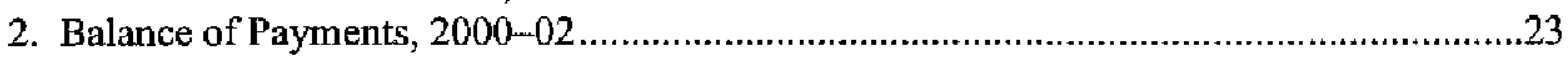

3. Summary of Consolidated General Government, 1999-2003 ..................................24

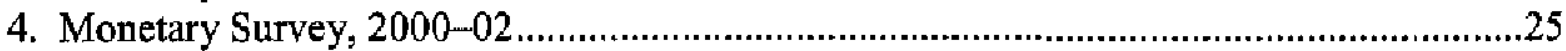

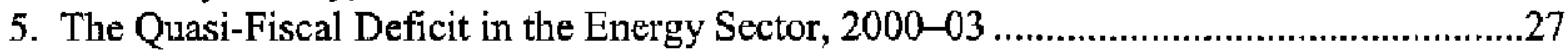

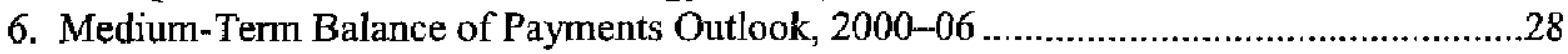

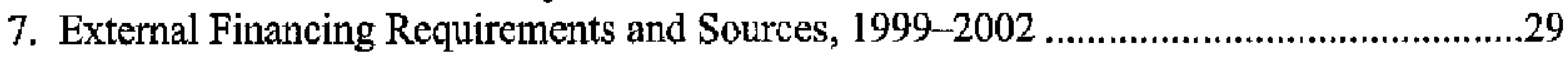

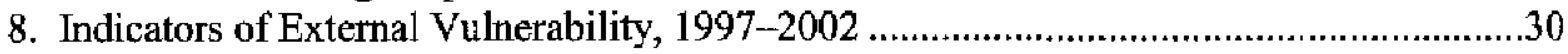

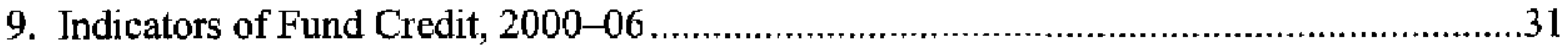

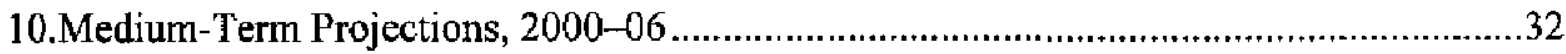

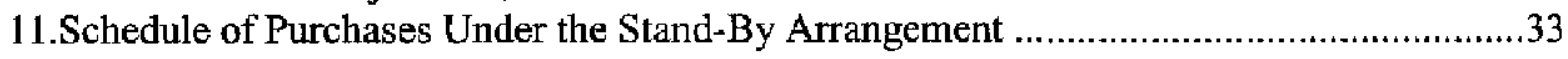

Appendices

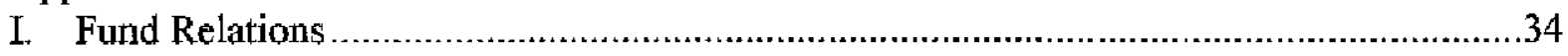

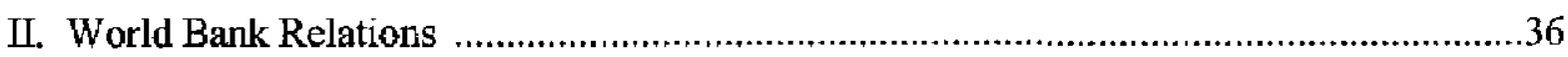

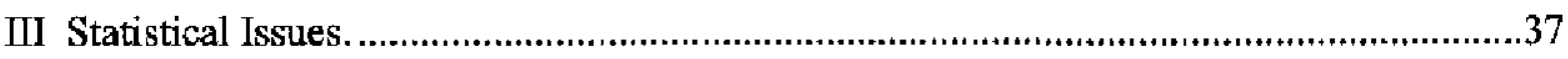

IV. Letter of Intent and Supplementary Memorandum on Economic and

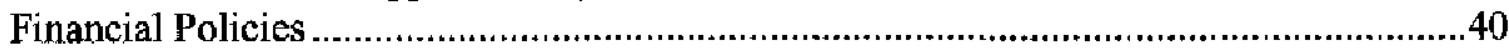




\section{INTRODUCTION}

1. On October 31, 2001, the Executive Board approved an 18-month Stand-By Arrangement (SBA) for Romania in the amount of SDR 300 million, or 29 percent of quota. Romania made a purchase of SDR 52 million upon approval of the arrangement. Discussions for the first and the second reviews under the SBA were held in Bucharest during January 28-February 5, March 25-29, and July 8-17, 2002.'

2. Upon approving the SBA, Executive Directors welcomed Romania's renewed commitment to stabilization and reform, but emphasized the need for strong policy implementation. Directors stressed that a further strengthening of the fiscal position and a reduction in the quasi-fiscal deficit, in particular in the energy sector, were crucial to the success of the program. While welcoming the measures to improve the structure of the tax system, they urged the authorities to resist pressures to grant ad hoc tax incentives and to sustain large loss-making enterprises by tolerating the accumulation of tax arrears. Directors noted with concern that a large number of industrial enterprises remained under state control and stressed the need to proceed expeditiously with the privatization program.

3. Since the inception of the program, macroeconomic developments have been favorable, but there have been slippages in structural policies. Performance on inflation and the external accounts has even been somewhat better than projected, and budget and monetary policies have been broadly in line with the program. However, progress in reducing the quasi-fiscal deficit fell short of the program target for 2001 and Q1 of 2002, and several performance criteria (PCs) were not observed. While the authorities implemented measures to moderate growth in public enterprise wages, program targets were not fully met. Employment reduction and privatization in state-owned enterprises have proceeded unevenly and with substantial delays. The authorities also concluded an agreement in June with two labor unions to increase the minimum wage sharply in January 2003. These developments increased the risk that stabilization would not be sustained.

4. To address the slippages under the program, the anthorities have agreed to implement corrective measures that are presented in the attached letter to the Managing Director (Appendix IV). Discussions on the completion of the reviews were protracted owing to delays in implementing several prior actions. Moreover, another mission

\footnotetext{
${ }^{1}$ The mission team included Messrs. Mates (head), Westphal, Gueorguiev, and Harjes (all EU1), Messrs. Brown and Lall (PDR), Ms. Rodic and Ms. Riggle (staff assistants EU1), and the Fund's resident representative, Mr. Cosse. The mission held discussions with Prime Minister Năstase, Governor of the National Bank of Romania (NBR) Isarescu, Minister of Public Finance Tanasescu, Minister of Labor Sârbu, Minister of Industry Popescu, Minister of Privatization Musetescu, Minister for EU Accession Puwak, Minister of Transportation Mitrea, and Minister for SMEs Ciornei. Ms. Marinescu, Advisor to the Executive Director for Romania, participated in most of the meetings.
} 
in July was required after the government's unexpected decision to increase the minimum wage. On the basis of the measures envisaged in the Supplementary Memorandum on Economic and Financial Policies (SMEFP), all of which have already been implemented, the authorities are requesting waivers for the nonobservance of three quantitative and three structural performance criteria (Box 1; Appendix IV, Table 1 and 2), and the completion of the first and the second reviews. They are also requesting a modification of a structural PC, postponing by two months the deadline for the privatization of the largest bank, BCR (SMEFP, $\{28)^{2}$. The remaining purchases under the SBA are, therefore, proposed to be rephased (Table 11) and the performance criteria for the third review to be based on the test date of September 30, 2002.

\section{Box 1: Request for Waivers}

Structural Performance Criteria

- Approval of the 2002 budgets of the state-awned companies by end-December 2001: The approval of a few budgets was delayed to January 2002 (see SMEFP, $\mid 6$ ).

- Increase in energy prices: All energy prices were adjusted as envisaged under the program (SMEFP, Table 3), with the exception of a somewhat lower effective increase in electricity prices in March 2002 due to two socially motivated measures (see SMEFP, $\uparrow 4$ ).

- Announcement of the tender for the privatization of BCR by end-February 2002: Due to the substantial delays in hiring a privatization advisor, the fully-fledged invitation for the expression of interest was not issued until June 24. Respective corrective measures are described in $\lceil 28$ of the SMEFP.

\section{Quantitative Performance Criteria}

- The end-March ceiling for the aggregate wage bill in state-owned enterprises was exceeded: The request for a waiver is based on corrective measures described in ๆ,17 and $ๆ 18$ of the SMEFP.

- The collection rates of the main utilities in Q1 of 2002 fell significantly short of the program targets: The request for waivers for two end-March PCs is based on conrective actions described in $q 22$ and $q 23$ of the SMEFP and improved performance in Q2 of 2002.

5. The government remains committed to the program, which is seen as crucial for accelerating EU accession. The government enjoys a comfortable majority in parliament (elections are scheduled for late 2004), but it has recently come under pressure from several trade unions, which have taken issue with the energy price increases, wage policy, and restructuring and privatization plans for the state-owned companies.

6. The World Bank has completed the negotiations on a Private Sector Adjustment Loan (PSAL II) that addresses privatization, the business environment, and energy sector reform. The deterioration in utilities' collection rates in late 2001 and early 2002 delayed the Bank Board discussion and prompted the Bank to field a mission in mid-March 2002 to discuss appropriate measures. Subsequently, the Bank Board meeting was postponed to (a) allow the government to sign a contract with an independent investment bank to

${ }^{2}$ Refers to the respective paragraph in the Supplementary MEFP. 
conduct a fairness assessment of the privatization of a company in the aluminum sector; and to (b) amend the privatization contract accordingly. Depending on the outcome, the Board meeting is tentatively scheduled to take place in September 2002.

\section{Recent Economic Developments and Performance Under the Program}

7. The Fund-supported program was designed in mid-2001 against the background of excessive domestic demand growth, stubbornly high inflation, and weak progress in reforms. In late 2000 and the first half of 2001 , rapid growth in household consumption was driven by excessive wage settlements in state-owned companies and a substantial increase in social transfers, one of the main factors behind the loose fiscal policy. The quasi-fiscal deficit in the energy sector widened as a result of delays in adjusting administered prices and weak collections. Consequently, the current account deficit, seasonally adjusted, ran at an unsustainable annual rate exceeding 7 percent of GDP. Meanwhile, the government moved slowly with privatization in the still very large sector of state-owned enterprises.

8. With the implementation of the program, growth in domestic demand slowed in late 2001 and early 2002 (Text Table 1). In addition to fiscal contraction, sharp increases in energy prices contained the growth in household consumption, indeed somewhat more than expected. Wage growth in the public sector also moderated. On the supply side, a strong recovery in agriculture in 2001 raised annual GDP growth to 5.3 percent. Industrial production, which had slowed in the second half of 2001 in line with weaker external demand, picked up in early 2002 .

Table 1. Romania: Maín Economic Indicators, 2001-03

\begin{tabular}{|c|c|c|c|c|c|c|c|c|}
\hline & \multicolumn{2}{|c|}{$200 \mathrm{~L}$} & \multicolumn{2}{|c|}{2002} & \multirow[t]{2}{*}{$200 \mathrm{~L}$} & \multicolumn{2}{|c|}{2002} & \multirow{2}{*}{$\frac{2003}{\text { Projection }}$} \\
\hline & H1 & $\mathrm{H}_{2}$ & $\overline{Q 1}$ & Q2 & & Progran & Projection & \\
\hline GDP (annual real growth) & 4.7 & 5.5 & 3.1 & $\cdots$ & 5.3 & 5.0 & 4,3 & 4.9 \\
\hline Final domestic demand (annual real growth) & 0.4 & 5.5 & 3.3 & $\ldots$ & 5.9 & 4.8 & 4.2 & 4.4 \\
\hline Nel exposts (conttibution to GDP growth) & -4.6 & -2.8 & 1.1 & $\ldots$ & -3.3 & -0.8 & -0.8 & -1.1 \\
\hline Current aecount (in peroent of annusl GDP) & -3.4 & -2.5 & -0.5 & .1 .1 & -5.9 & -5.6 & .5 .1 & -4.9 \\
\hline Arnual Inflation (eop) & 35.7 & 30.3 & 25.1 & 24.0 & 30.3 & 22.0 & 22.0 & 15.0 \\
\hline Officia) rescrves (cop, US\$ billion) & 4.6 & 4.9 & 5.1 & 5.7 & 4.9 & 5.0 & 6.0 & 7.0 \\
\hline
\end{tabular}

Sornces: National Instirute for Statigtics; Ministry for Econamie Development and Forecasting; and Fund staff projections.

9. Disinflation proceeded somewhat faster than projected. The deceleration in nominal wage growth and the depreciation rate, supported by the recovery in agriculture and moderation in consumption growth, helped reduce the 12-month inflation rate from 36 percent to 24 percent over the year to June 2002 . This notable reduction was achieved despite large adjustments in administered prices. Underlying inflation (CPI excluding administered prices) fell to 20 percent in June (Figure 1). 
Figure 1. Consumer Price Index (CPI) and Net Wages, 2000-02

Perçent

(12-month rate)

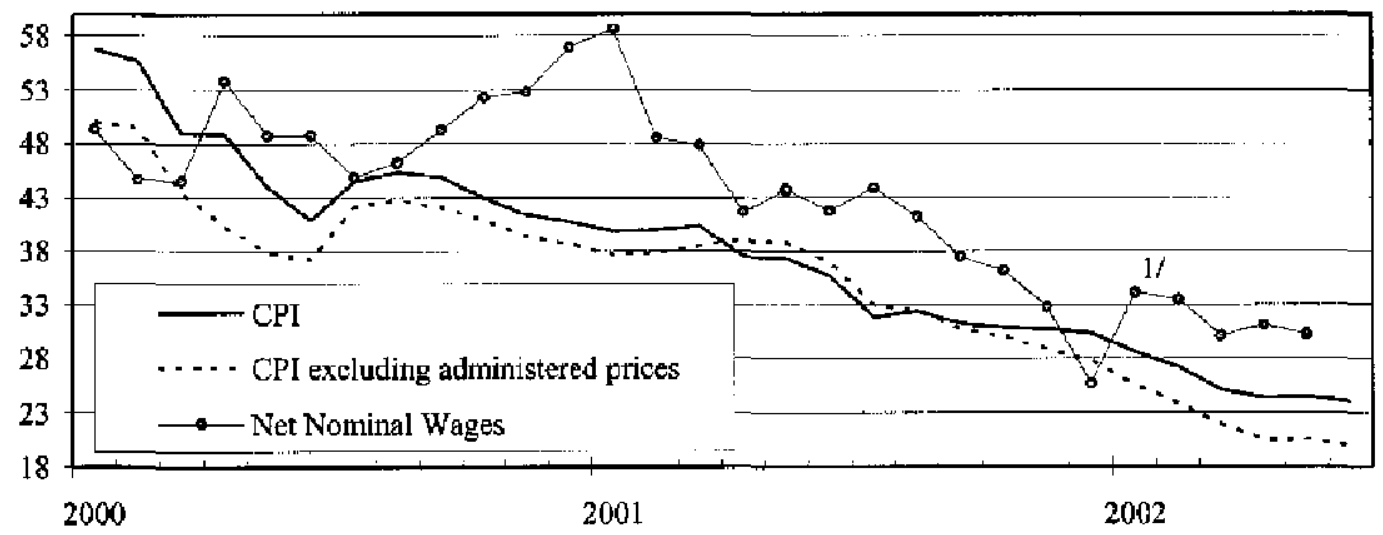

Source: Romanian Authorities; and Fund staff estimates.

I/ The particularly low increase in December 2001 and the spike at the beginning of 2002 are primarily due to a postponement of bonus payments.

10. Progress in disinflation contributed to preserving external competitiveness. Over the last two years, the real effective exchange rate was stable in ULC terms and appreciated only modestly in CPI terms, adjusted for administered price corrections (Figure 2). In the same period, Romania has also rapidly increased its EU market share, and its export performance is among the best in the region (Text Table 2).

\section{Developments in the external} current account have been increasingly favorable. As envisaged, the current account deficit declined in the second half of 2001 , and for the year as a whole it was near the target of 6 percent of GDP. Exports weakened in the second half of 2001 in line with the slowdown in Europe, but as

\begin{tabular}{lcc}
$\begin{array}{l}\text { Table 2. Export Performance of Romania arxd Neighboring } \\
\text { Countries, Annual Averages } \\
(2000-01)\end{array}$ & $\begin{array}{c}\text { Export } \\
\text { Growth } 1 /\end{array}$ & $\begin{array}{c}\text { EU Export } \\
\text { Shares 2/ }\end{array}$ \\
\hline \multicolumn{3}{c}{ (In percent) } \\
Bulgaria & 14.8 & 2.5 \\
Croatia & 5.3 & -3.6 \\
Czech Republic & 7.9 & 2.8 \\
Hungary & 9.9 & 6.5 \\
Poland & 8.2 & 1.9 \\
Romania & 16.5 & 5.6 \\
Slovak Republic & 9.0 & 3.0 \\
Slovenia & 4.0 & -7.9 \\
\end{tabular}

Source: DOTS and staff estimates.

1) In U.S. dollar terns.

2) Change in ratio of exports to the EU over total EU imports. domestic demand moderated, imports also dropped (Figure 3). The somewhat higher trade deficit was offset by improved terms of trade and higher transfers. In early 2002, exports started to grow again, while imports remained below program projections, helped in part by the decline in the cost of energy imports. As a result of a better balance in trade and services and high growth in current transfers, the current account deficit for January-May fell to 1.5 percent of annual GDP, much below the program projection. 
Figure 2. Real Effective Exchange Rate, 1996-2002

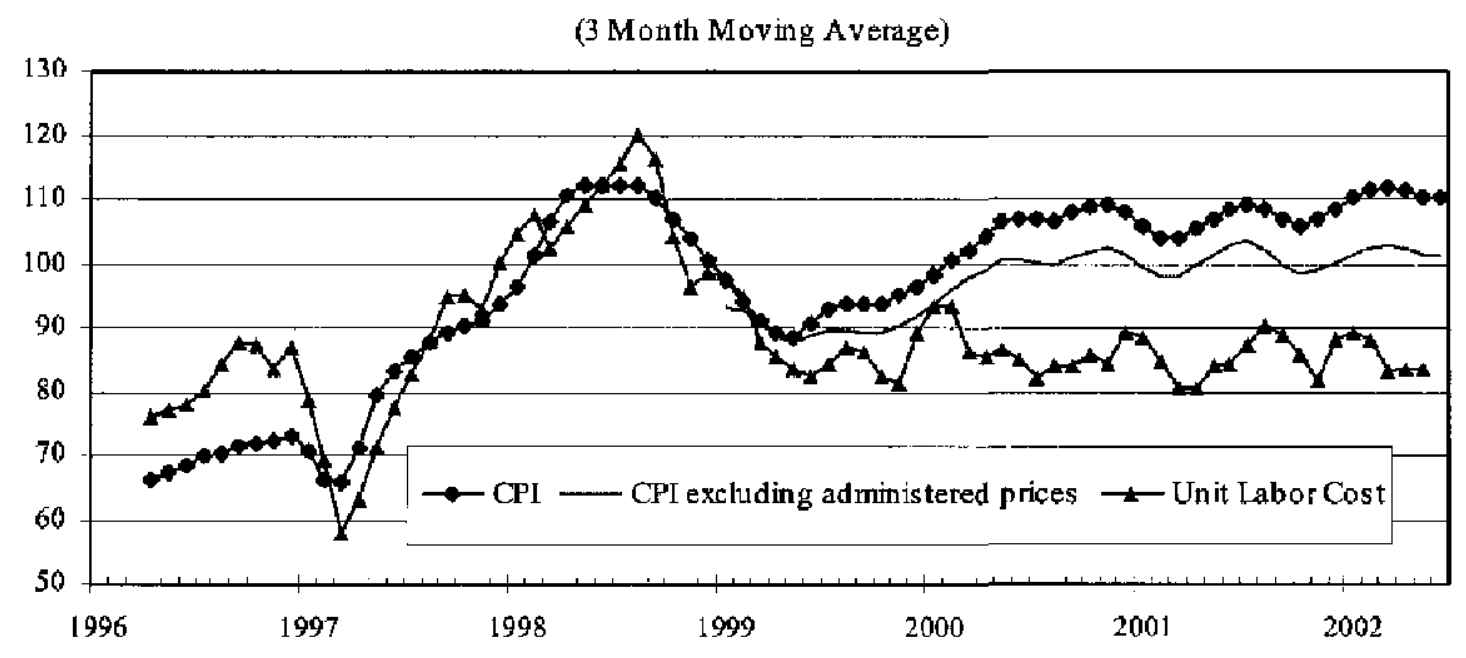

Source: Romanian authorities and Fund staff calculations; only include advanced economy partners.

12. The balance of payments position strengthened more than projected. The endDecember 2001, end-March and end-June 2002 NFA targets were exceeded by a large margin. Market sentiment toward Romania has improved, and external sovereign bond spreads have narrowed significantly over the past year, outperforming its asset class (Figure 4). Romania's sovereign foreign currency risk has also recently been upgraded (Moody's raised Romania's grade from B3 to B2 in December 2001, S\&P from B to B+ in April 2002).

13. Monetary policy has sought to lower inflation while avoiding an inappropriate real appreciation of the leu. To sustain disinflation, the NBR reduced policy interest rates only gradually up to April (Figure 5), with real rates remaining within a range of 11-12 percent. In May, faster-than-expected disinflation and sustained robust demand for leidenominated assets, accompanied by an excess supply of foreign exchange, prompted the NBR to reduce interest rates on its sterilization instruments by $2 \frac{1}{2}$ percentage points, which brought the real interest rate to 10 percent on a 12 -month forward-looking basis. NBR's frequent purchases in the foreign exchange market have simultaneously ensured a sustained nominal depreciation of the leu (Figure 4). 
Figure 3. Romania: Exports, Imports and Trade Balance, 1993-2002

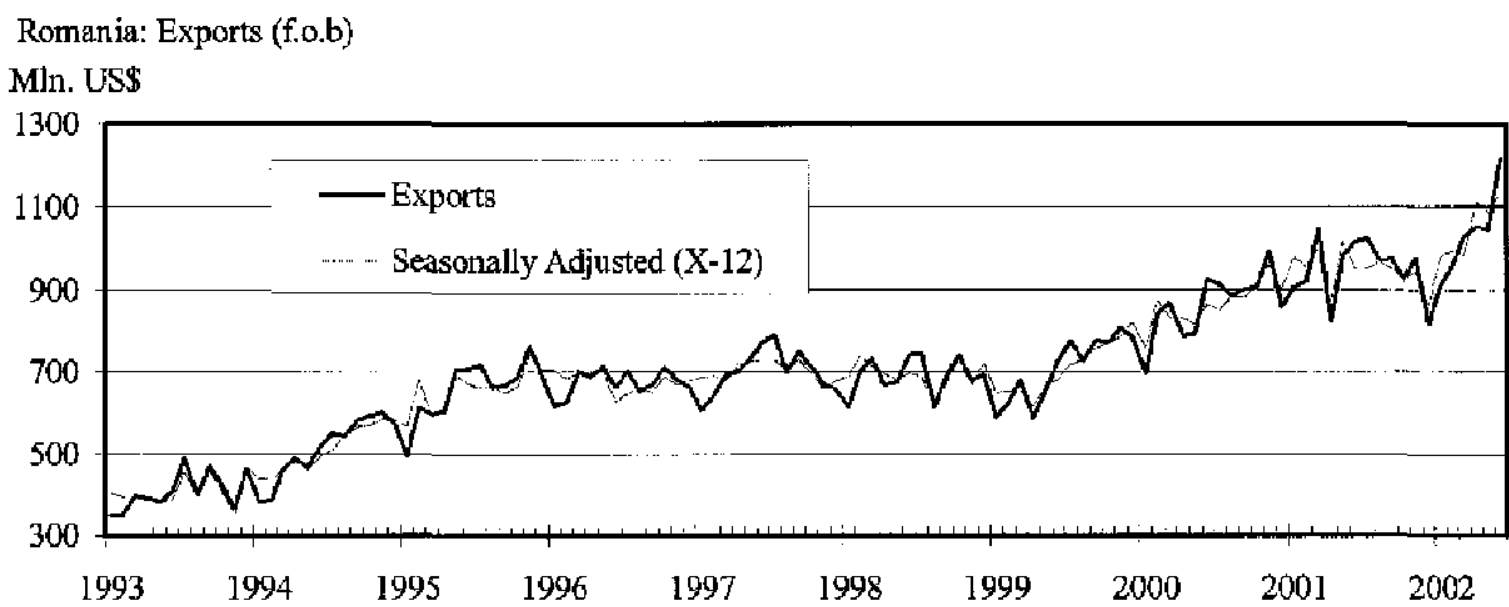

Romania: Imports (f.o.b)

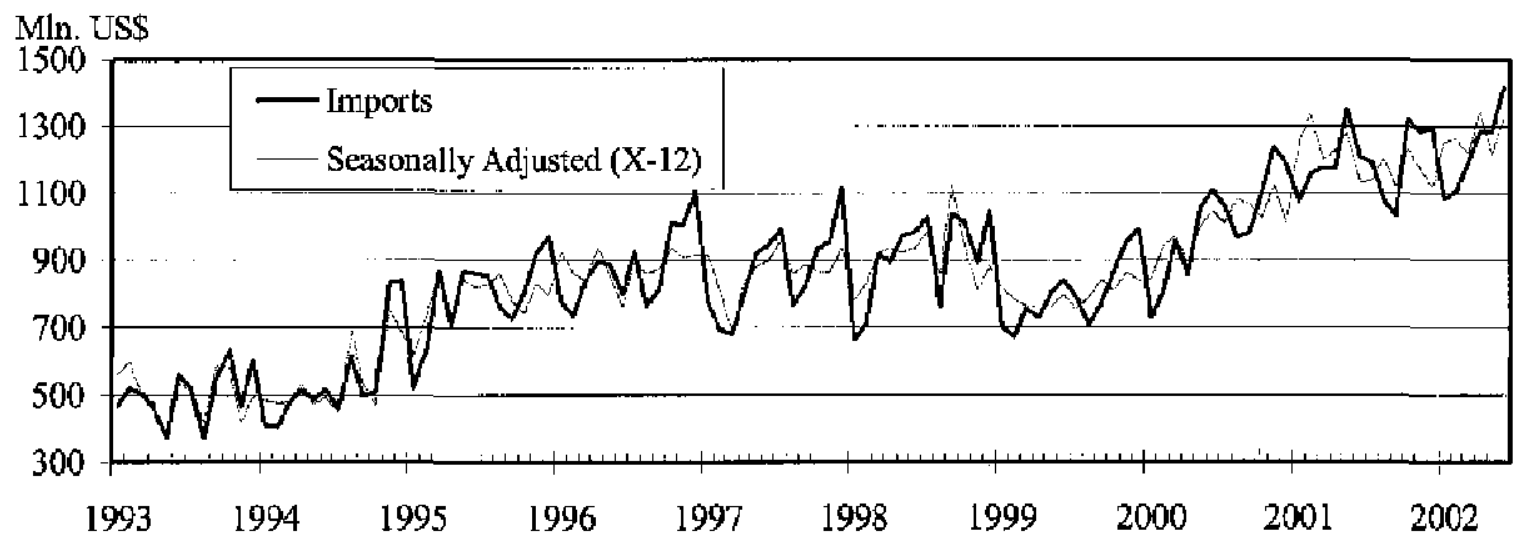

Romania: Trade Balance (f,o.b)

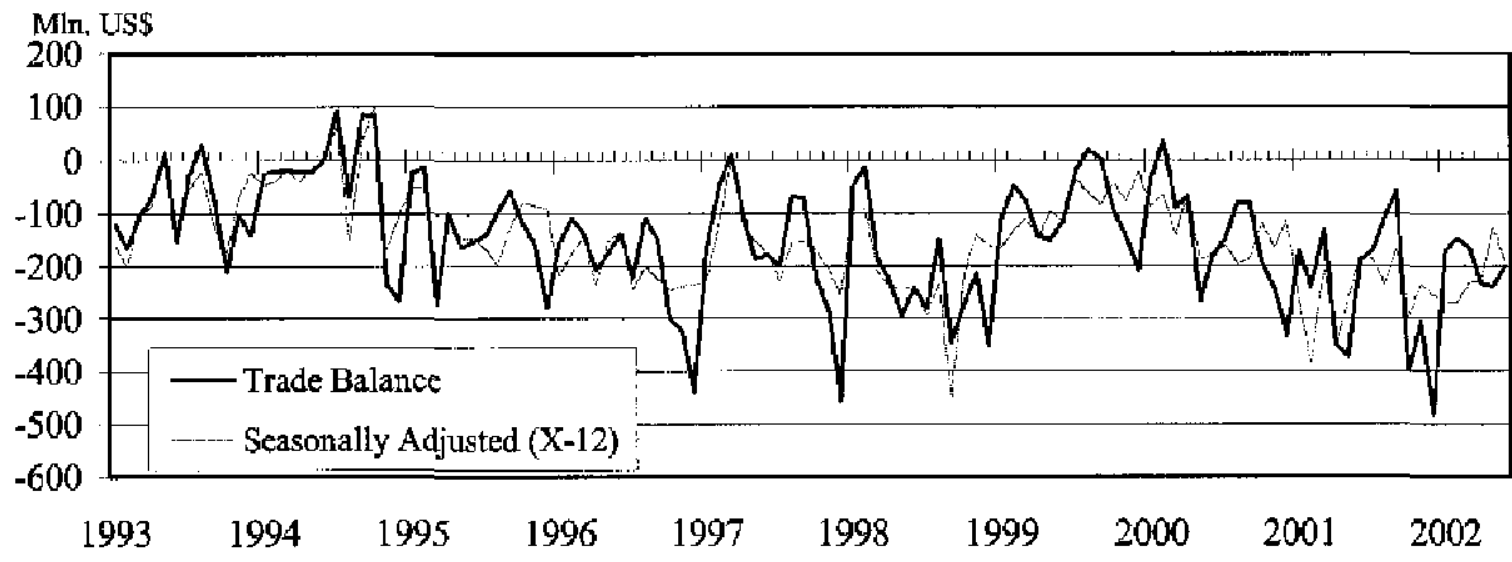

Source: Romanian authorities and Fund staff estimates.

CInternational Monetary Fund. Not for Redistribution 
Figure 4. Romania: Reserves, Exchange Rates, and Bond Spreads, 2000-02

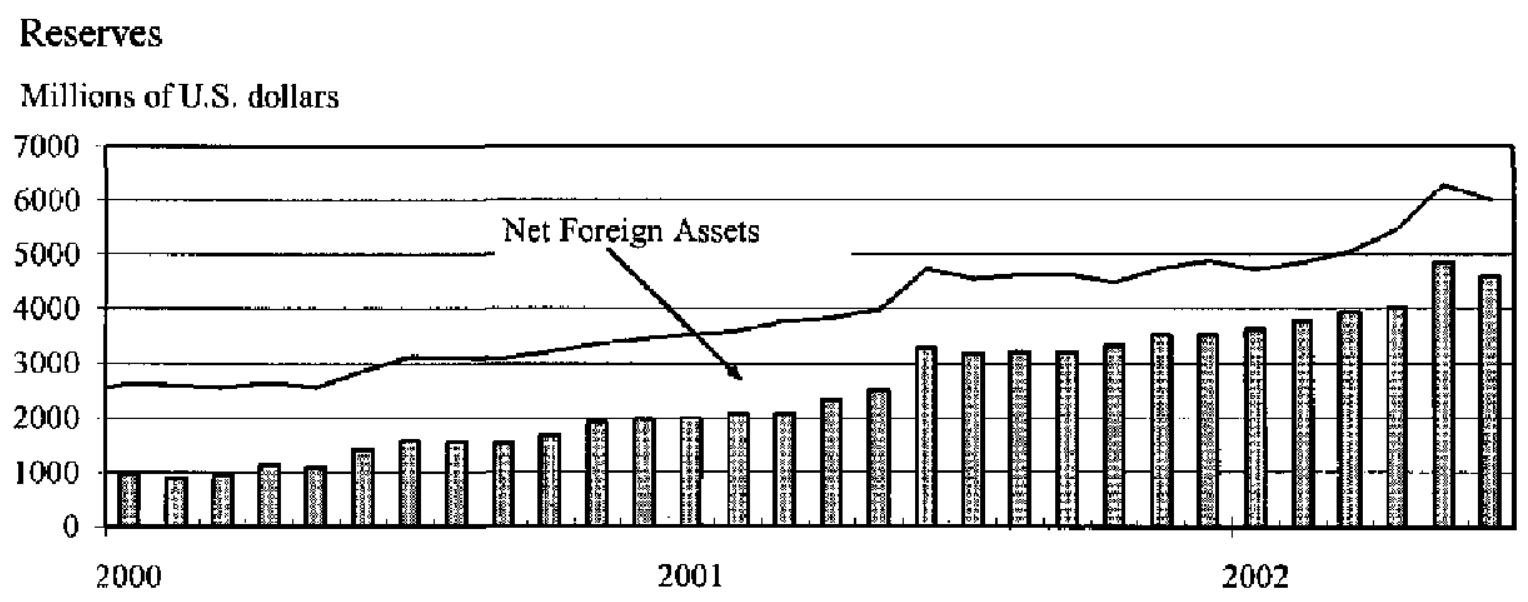

Monthly Depreciation Rate of Lei, Three-month Moving Average

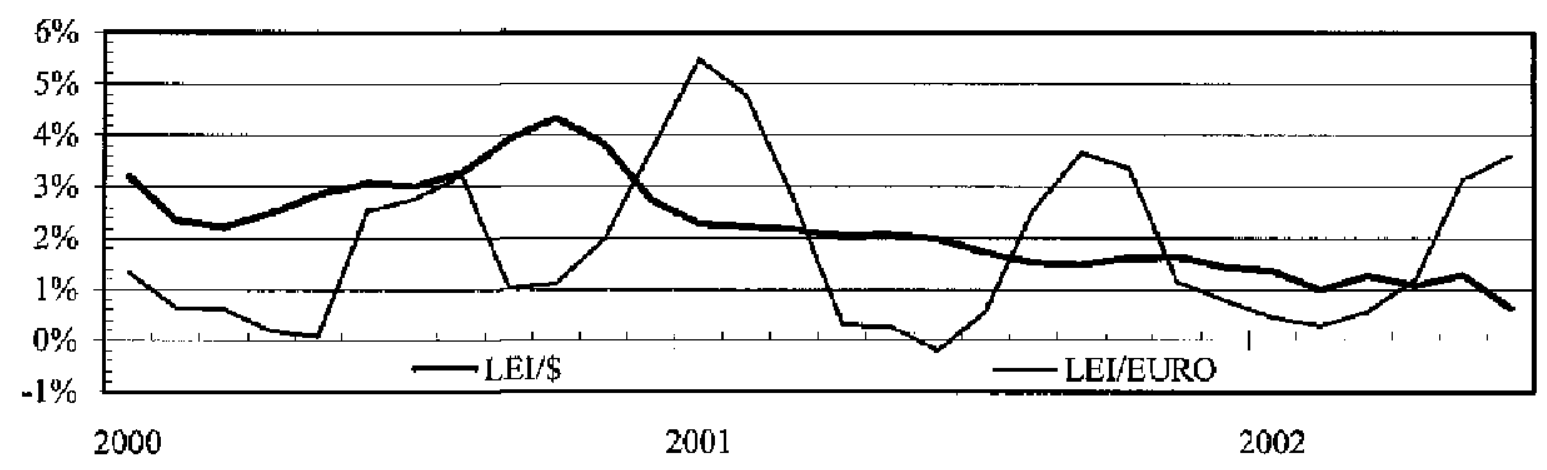

Bond Spreads

Basis points

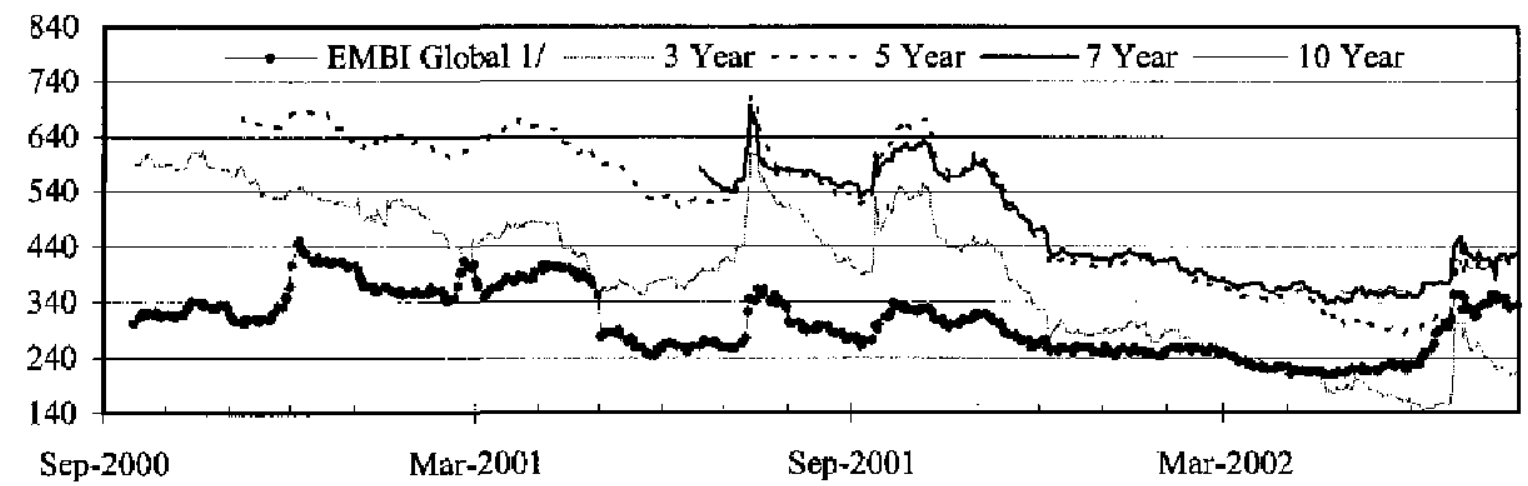

Sources: Romanian authorities; Fund staff calculations and Bloomberg.

1/ Euro EMBI Global index excluding Latin America. 
Figure 5. Romania: Nominal Interest Rates, 2000-02

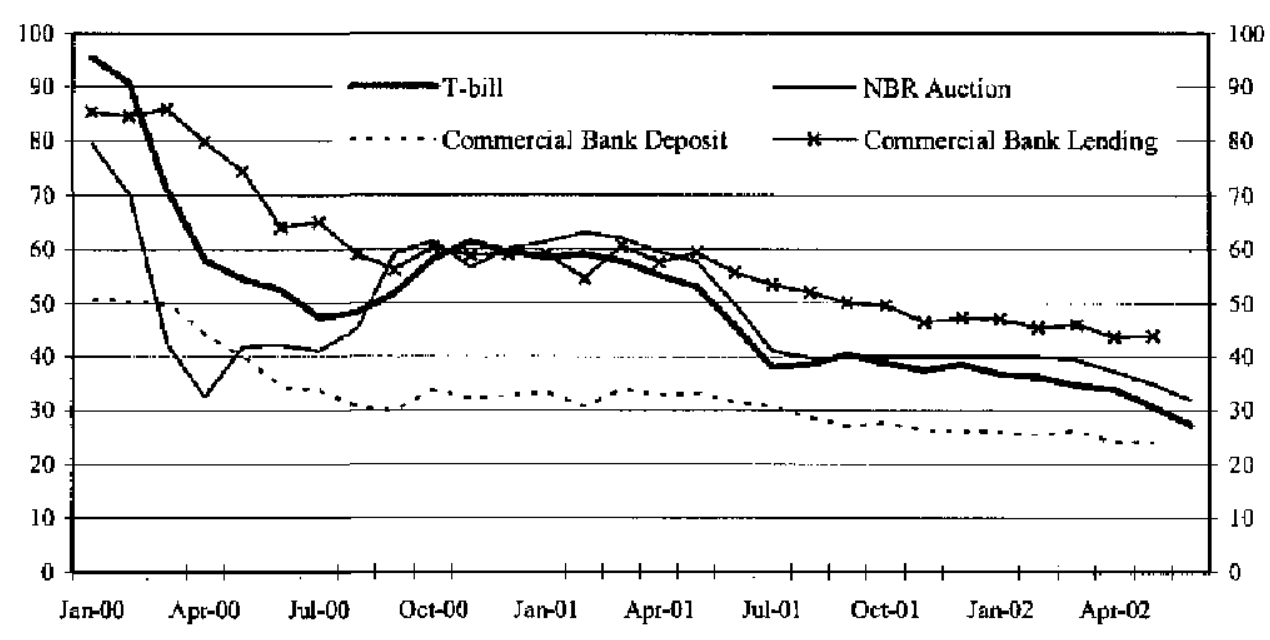

Sources: Romanian Authorities; and Fund staff estimates.

14. A process of reverse dollarization is under way. With disinflation firmly on track and the NBR foreign reserves steadily rising, the exchange rate risk perceived by investors dropped. This has led to a rebalancing of portfolios in favor of lei assets (notably time deposits and T-bills), and foreign currency liabilities (notably loans from domestic banks). As a result, growth in lei broad money rose to about 20 percent in real terms in May. The T-bill yield curve has continued to shift downward, and has been inverted for more than a year now, indicating that expectations for further disinflation are stable (Figure 6).

Figure 6. Romania: T-Bill Yield Curve, 2001-02

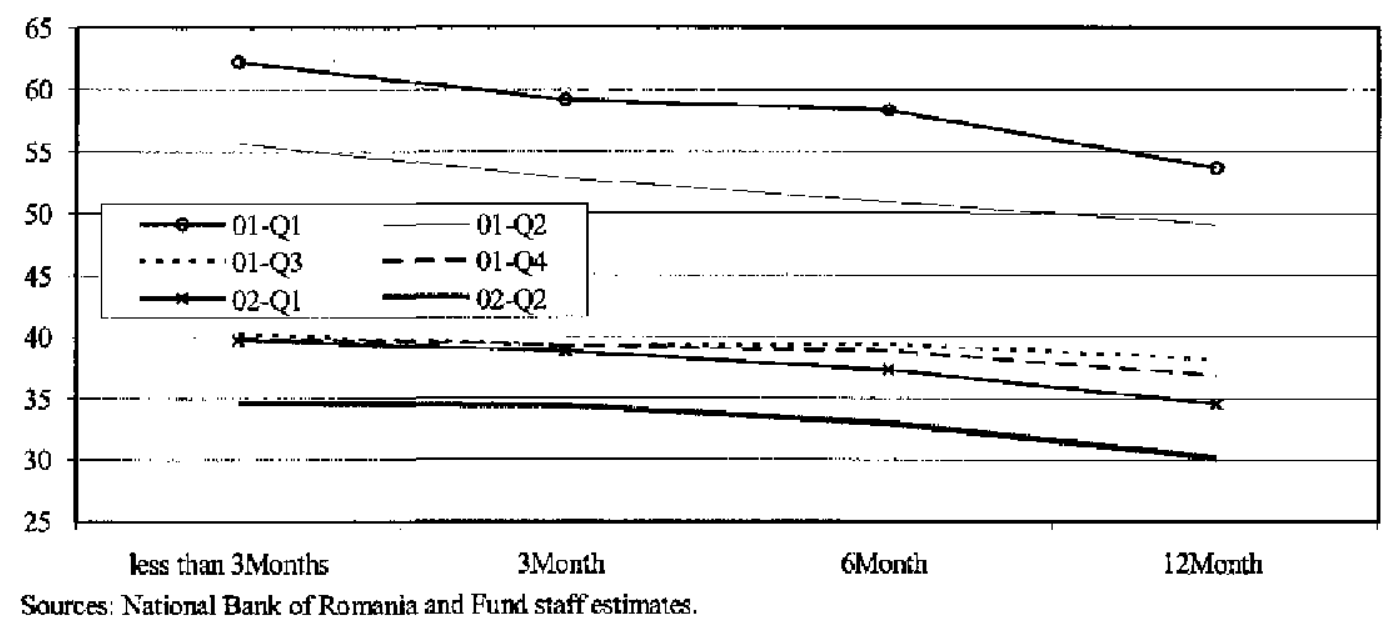


15. Bank credit to the nongovernment sector has accelerated, recently reaching an annual growth rate of $\mathbf{3 4}$ percent in real terms. Particularly rapid was the growth in foreign-currency-denominated lending, financed primarily by a decline in commercial banks" net foreign assets. This credit continues to be less costly but exposes lenders to greater credit risk. The stock of credit to the state-owned sector remains modest and, except for the energy sector, is not growing in real terms.

\section{The budget deficit has been on track, but a significant revenue shortfall has} increased risks (Text Table 3 and Table 3). Following the expansionary fiscal stance in the first nine months of 2001 , as the new government tried to deliver on some of its election commitments, fiscal policy was significantly tightened in Q4 of 2001, in line with the program. The revenue shortfall, stemming primarily from the lower-than-expected improvement in the collections of social security contributions after the introduction of the new pension law, carried over to 2002. Nevertheless, the deficit targets at end-March and end-June were met, primarily by reducing subsidies and transfers.

Table 3. General Government Deficit and Qunsl-Flscal Deficlt in the Evergy Sector

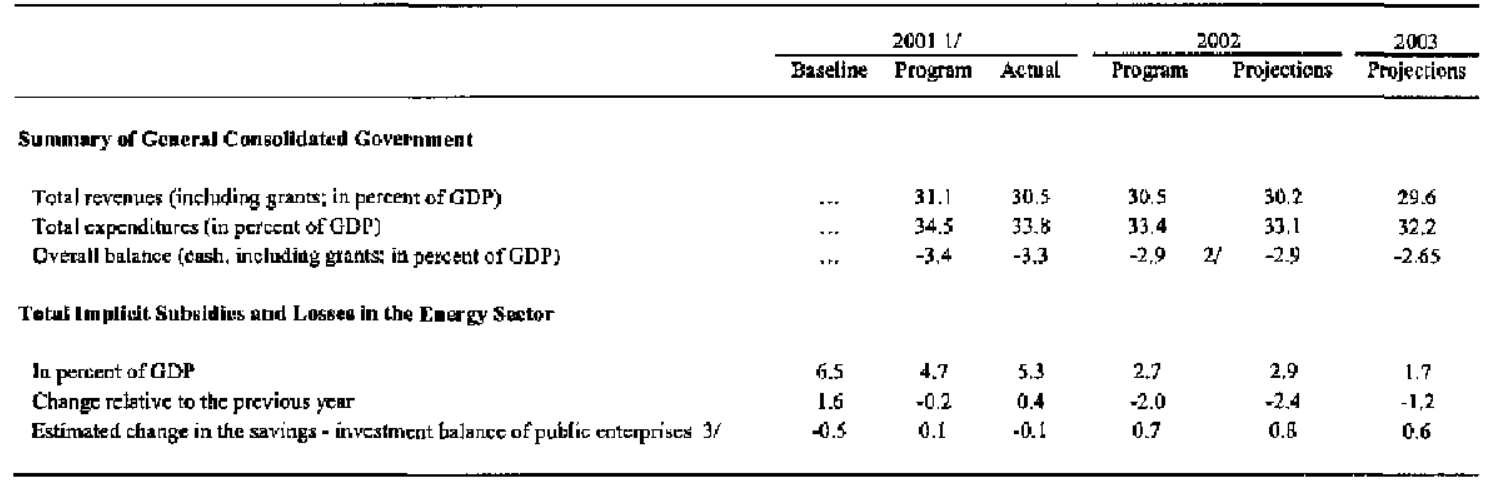

\footnotetext{
Sources: ANRE (electricity regulstory agency). Termoe]ectriea and Digrrigaz Nard and Sud; World Bank; and. Fund staff estimates.

1i Basad on ravised 2001 GDP.

2/ The otigitsal target fot the nominal budget deficit was equivalent to 3.0 percent of GDP. The upward revision of the nominal GDP was reflected in a lower deficit target it tettos ofGDP.

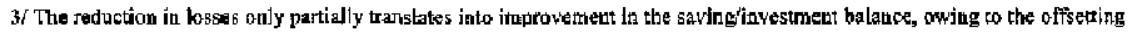

factors: (i) temporary increases in losses is orhesr public enterprises; (ii) higher tax payments of the encrgy scctor, and (iii) higher invesiment is the encrgy sector:
}

17. The ambitlous schedule for increases in energy prices envisaged under the program has been implemented. Between June 2001 and June 2002, household gas prices increased by 116 percent, electricity prices by 47 percent, and heating prices by 71 percent, with an additional 33 percent becoming effective in August 2002. (The new heating price will still be below the production costs of most suppliers, requiring subsidies to suppliers to remain in place.) The only exception relative to the program targets was the reduction in electricity subscription charges in March 2002, motivated by social concerns, which led to the nonobservance of a structural performance criterion for March 2002 by a small amount (SMEFP, ๆ4).

18. Progress in reducing the quasi-fiscal deficit in the energy sector, however, fell short of program targets, as collections by the main utilities failed to improve (Table 5 ). 
Reflecting insufficient efforts, the collection rates for heating deteriorated in Q4 of 2001 and Q1 of 2002, while the improvement in electricity collections was lower than targeted. As a result, the two end-December 2001 and two end-March 2002 PCs on the collection rates were missed by substantial margins (SMEFP, $\mid 5$ ). Some improvernent was achieved in Q2 of 2002.

19. The $\mathbf{2 0 0 2}$ wage program benefited from an early approval of state-owned companies' budgets. While the 2001 budgets were approved only in $\mathrm{Q} 3$ of that year, most of those for 2002 were finalized by end-2001, except for a few that were approved in January 2002. This short delay resulted in the nonobservance of the corresponding end-December 200 I structural PC, but it did not have a substantive impact on policy implementation (SMEFP, T6).

20. Wage growth in public enterprises moderated, but less than envisaged, and recently wages in this sector have again outpaced those in private companies (Figure 7). The end-December 2001 target for the annual wage bill in monitored companies was missed by 2.3 percent, and the shift of bonuses to Q1 of 2002 led to an even larger deviation from the admittedly tightly set end-March 2002 target. The end-June target was also likely missed by 2 percent. The weak performance reflected, inter alia, a failure to reduce employment in companies under the Ministry of Industry by 8,000 positions in Q4 2001, as envisaged. Subsequently, about 5,000 layoffs were completed by early July 2002 as a prior action, which was part of the program to reduce employment in state-owned companies by 3.9 percent in 2002 .

Figure 7. Net Wages, 12-Month Real Growth Rate, 2000-02 1/

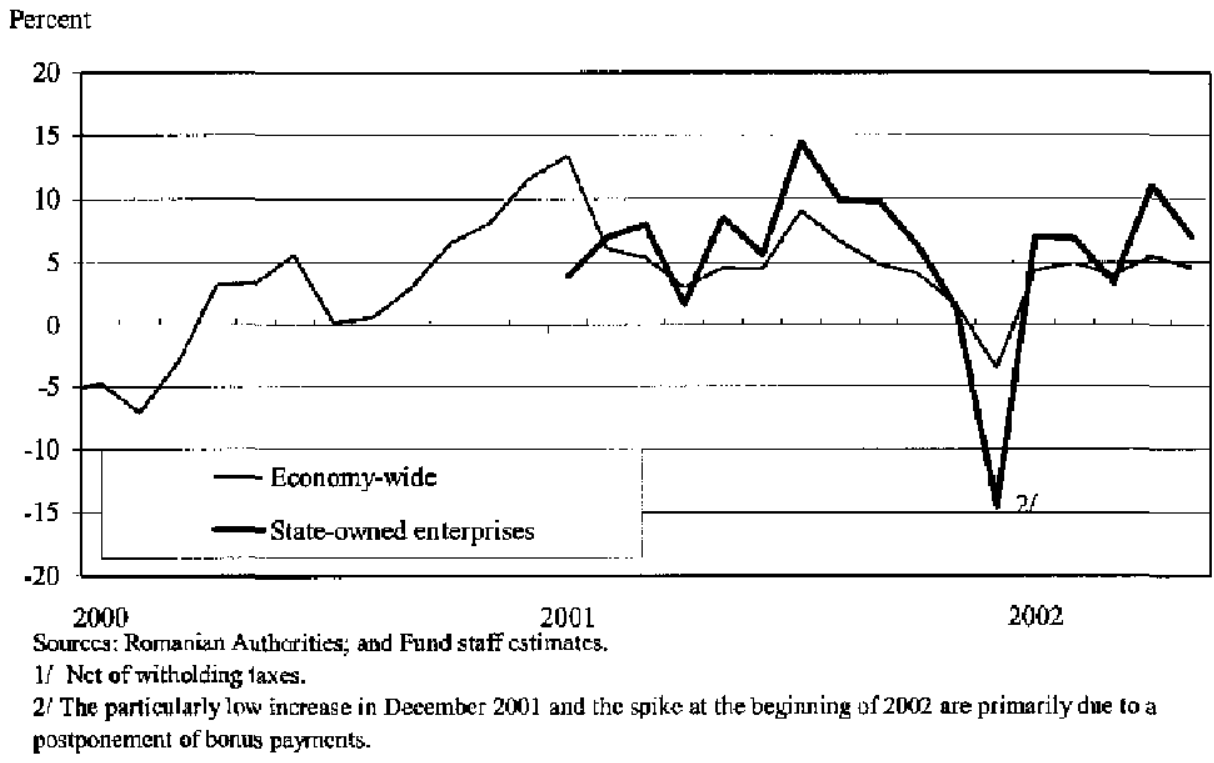

21. In June $\mathbf{2 0 0 2}$, the authorities signed an agreement with two labor unions, putting at risk program objectives, particularly in respect to wage policy in state-owned 
enterprises. The agreement provided for an increase in the minimum wage by around 43 percent as of January 2003. Moreover, it envisaged that the employees' social security tax rate would be cut by 4.7 percentage points (and that of employers by 0.3 percentage point), which would further boost consumer wages in early 2003 . The agreement also gave labor unions a more prominent role in the privatization process.

22. Progress on privatization has been slow and structural benchmarks have not been met. On the positive side, steel producer Sidex-with 27,000 employees, the largest state-owned company outside the energy sector-was privatized in late 2001 . On the other hand, only 6 other companies with more than 1,000 employees were privatized between September 2001 and March 2002, compared with the program target of 12 such companies. In March, however, the authoritics launched tenders for 28 companies with 46,700 employees. Meanwhile, delays in the privatization of a profitable aluminum company along with frequent delays and changes in the terms of privatization in other cases have heightened concerns about transparency.

23. The privatization of the largest bank, BCR, has been delayed. The contract with the privatization advisor was signed on June 5, after a nine-month delay. As a result, the fullfledged invitation for expressions of interest by potential investors was delayed from cndFebruary 2002 (a structural PC) to June 24, 2002, leading to the nonobservance of the corresponding structural $\mathrm{PC}$.

24. The NBR has made progress in introducing new banking regulations. The amended regulation on open foreign currency positions, effective January 1, 2002, helped reduce the risks from rapid changes in currency cross rates by introducing currency-specific limits. With the aim of strengthening efforts to combat money laundering, the NBR also adopted a "know-your-customer" regulation.

\section{Policy Discussions}

25. With macroeconomic developments generally favorable and on track, discussions focused on slippages in wage policy, energy sector reforms, tax reforms, and the need to accelerate privatization. The authorities, in sharing the objectives of sustained stabilization, curbing the quasi-fiscal deficit and completing privatization, agreed to additional measures that reaffirmed the original understandings under the program. However, they also emphasized the social effects of the recent reforms, and explained in this context that their decisions to increase the minimum wage and reduce social security taxes were intended to compensate low-income households for the energy price increases under the program.

26. There was basic agreement on much of the macroeconomic framework for 2002 and 2003, the exception being the inflation target for 2003. It was agreed that the current account deficit should be brought below 5 percent of GDP in 2003, and official reserves targeted to increase to a comfortable level of 4.1 months of imports by end-2003. GDP growth is projected at $4 \frac{1}{4}$ percent in 2002 and about 5 percent in 2003. Despite the recent 
downward revision in growth prospects in the main trading partners, Romania's robust export performance thus far suggests that the risk to the growth projection is limited. It was agreed that the gradual disinflation strategy remained appropriate, reflecting the difficulties in eliminating wage-inflation inertia. With the headline inflation target of 22 percent for 2002 safely within reach, but still well over twice the aim of reducing inflation to single digits by 2004 , the staff argued for targeting 12-13 percent for 2003 . This would, however, require that the minimum wage hike in early 2003 be moderated. The authorities did not wish to modify the decision on the minimum wage, and opted for a less ambitious inflation target of 15 percent.

27. As in the origlnal program, the main elements of the policy strategy are a reduction in the fiscal and quasi-fiscal deficit and a wage control program, which would allow for a gradual slowdown in currency depreciation withont adversely affecting competitiveness. Fiscal policy targets a reduction in the overall deficit of $1 / 2$ percentage point of GDP in 2002 (as originally envisaged) and of $1 / 4$ percentage point in 2003 , while the improvement in the quasi-fiscal deficit would amount to 0.8 percentage point of GDP in 2002 and 0.6 percentage point in 2003 . The authorities originally envisaged a smaller fiscal correction in 2003 , but acknowledged that the more ambitious target was necessary to offset the effect of the minimum wage increase on aggregate demand.

\section{A. Fiscal Policy}

28. The challenge facing fiscal policy is to meet the agreed deficit targets in the face of partly unexpected, but also partly policy induced, weakness in revenues. Specifically:

- To ensure that the 2002 deficit target is met the authorities decided to increase some taxes and broaden the tax base. The excises were raised closer to the EU levels, and a distortionary preference for domestic tobacco was eliminated (SMEFP, 『10). Moreover, a new law on part-time employment will broaden the tax base by imposing the obligation to pay pension contributions for the so-called "civil work contracts."

- Notwithstanding these measures, staff forecasts a shortfall of revenues relative to the budget target of about 0.3 percent of GDP, which is offset by expenditure savings. Specifically, in addition to the savings in interest expenditures, non-pension related expenditures of the pension fund, and cofinancing of EU grants for a total amount equivalent to about 0.5 percent of GDP, the government decided to freeze expenditures of the special road fund in an amount equivalent to 0.1 percent of GDP. With a view to meet the original nominal deficit target, the supplementary budget approved on July 31 increased noninterest expenditures by only about 0.3 percent of GDP.

- For 2003 , the challenge is to cope with the reduction in payroll taxes and the lower deficit target by containing expenditures. The preliminary understanding on the 2003 budget implies that growth in non-interest expenditure will need to be restricted to about $2 \frac{1}{2}$ percent in real terms. While the authorities have already decided to reduce subsidies by at least 0.4 percentage point of GDP and limit the growth in the net wage bill of the 
budgetary sector to 3 percent in real terms (SMEFP, $\uparrow 13$ ), further expenditure reductions will need to be identified during detailed discussions on the 2003 budget in September. With heating support to low-income households and child allowances envisaged to increase, other transfers will need to be closely scrutinized. The projected increase in EU grants will allow financing of an increase in capital expenditure by 0.2 percent of GDP, in line with medium-term objectives.

29. In time, revenue performance will benefit from the completion of an ambitious tax reform that will also improve the tax structure. Following the approval of a new excise tax law in late 2001 and the decision to cut payroll taxes by 3 percentage points in January 2002, discussions in the context of the reviews focused on the completion of the VAT and profit tax reforms, and further cuts in payroll taxes. Specifically:

- A new VAT law, which became effective on June 1,2002, eliminated several exemptions and zero ratings, including for small and medium-size enterprises, with a view to increasing the very low VAT revenues in terms of GDP (SMEFP, 111). The authorities acknowledged that the assumed social benefit of introducing a second, lower VAT rate, would be modest relative to the substantial revenue loss this would entail. They agreed that social concerns about the effects of the new law on housing constnuction should be addressed with well-targeted subsidies.

- The new profit tax law, effective July 1, 2002, drafted in consultation with staff, eliminated distortionary tax holidays, and exemptions under several laws, replacing them with a uniform investment tax allowance (SMEFP, 111). The law also provides for a schedule for increasing the reduced profit tax rate for exporting activities, which had been seen by the European Commission as undermining competition, to the standard 25 percent rate.

- Although the authorities originally intended to reduce the very high payroll taxes primarily for employees, with a view to increasing their disposable income, they recognized that a balanced split of the tax cut between employers and employees would be more conducive to a positive supply response and to alleviating unemployment.

30. A comprehensive tax administration reform has been initiated. Following the recommendations of the Fund's Fiscal Affairs Department, the government decided to (a) create a unified tax administration department within the Ministry of Finance;

(b) establish a large taxpayer directorate in Bucharest; and (c) integrate the three existing administrations for the collection, audit, and enforcement of social security contributions into a single new administration under the Ministry of Finance (SMEFP, ๆ15).

\section{B. Wage Policy}

31. The authorities acknowledged the importance of strengthening wage discipline in state-owned enterprises. Following the nonobservance of the December 2001 and March 2002 targets for the wage bill of state-owned companies, they approved quarterly ceilings for 
the wage bills and employment in about 80 of the largest companies and decided to further limit bonus payments (SMEFP, $\mid 17$ and 18). The staff, therefore, supports the authorities" request for the waiver of the nonobservance of the corresponding end-March performance criterion.

\section{Discussions on wage policy in 2003 focused on the implications of the minimum} wage hike. Staff noted that while the direct effects of this measure appeared to be small ( 0.3 percent of GDP in additional wage payments), in the past such adjustments had typically triggered overall wage increases in public enterprises, owing to a complex system of collective contracts relying on the minimum wage as a benchmark. This concern was amplified by evidence that the base wages in many sector-wide collective contracts would be below the new minimum wage. Furthermore, staff emphasized the negative effects on private sector employment and growth in some sectors.

\section{The authorities explained that they saw the minimum wage increase as an} important social commitment to offset the effects of the energy price adjustments on low-income households. Moreover, they expected that this measure would reduce tax evasion, given indications that unreported wage payments in the private sector were widespread. They were not concerned about the secondary effects on the overall wage level, as apparently most collective contracts at the enterprise level no longer included aufomatic adjustment in the wage scale linked to the increases in the statutory minimum wage. Nevertheless, to attenuate the effects of the minimum wage decision on economy-wide wage developments, the authorities agreed to implement measures specified in $\llbracket 19$ and 20 of the SMEFP.

\section{Energy Sector Reforms}

\section{The authorities have made good progress in adjusting energy prices to more} viable levels. In the last round of electricity price adjustments on April 10, the producer price for Termoelectrica was increased to above production costs, while the margin for Electrica was increased to compensate for the effects of the reduction in the fixed charges for households. (Staff therefore supports the authorities' request for a waiver of the nonobservance of the March structural performance criterion on electricity prices due to this measure.) Going forward, the authorities intend to adjust all electricity prices on a quarterly basis to prevent their erosion in U.S. dollar terms, a measure that was not included in the original program.

35. Progress has been more mixed with regard to the collection rates of the utilities. Following weak performance in 2001 and Q1 of 2002, the authorities agreed to strengthen payment discipline, including by discontinuing supplies to large industrial users with a weak payment record (SMEFP, 122 ). These measures led to an improvement in performance in Q2 of 2002, especially in the gas sector. However, collection performance in the district heating sector deteriorated further. In this regard, the authorities have taken initial steps toward decentralizing the heating system, which will increase the local authorities' incentives to improve the collection performance and seek more efficient sources of heating supplies. 
Based on the implemented measures, the staff supports the authorities" request for waivers of the nonobservance of the two end-March PCs on collections rates.

36. Privatization in the energy sector is now expected to proceed. Staff urged the authorities to accelerate privatization in the energy sector. Following substantial delays in this process, the authorities have agreed to sign the contract with the privatization advisor for the two gas distribution companies by end-December 2002, to approve the privatization strategy by end-March 2003, and to announce the privatization tender by end-May 2003 (SMEFP, ๆ24). They also agreed to give priority to the full privatization of two electricity distribution companies, instead of limiting private sector capital injection to 35 percent of equity.

\section{Monetary Policy and Banking Supervision}

\section{There was agreement that success in disinflation and strong demand for lei} assets had ereated scope for cutting interest rates. In light of slowing domestic demand and a faster-than-expected decline in inflation, staff supported the recent NBR decisions to cut the interest rate on its sterilization instrumonts to 30 percent, a level consistent with the disinflation objective. The NBR's purchases in the foreign exchange market will aim at preventing unwarranted real effective appreciation, with the estimated Balassa-Samuelson effect serving as a broad reference in this respect. The NBR unified reserve requirements for lei and foreign currency deposits at 22 percent (from 25 percent and 20 percent, respectively) from April 1, thus removing the bias in favor of foreign currency deposits.

\section{Staff expressed concern, however, about the continuing rapid expansion of} foreign-currency-denominated credit. Lending in foreign exchange has exposed the banks to higher credit risk, particularly in light of deficiencies in the regulation on loan provisioning. The authorities considered that overall real credit growth was not a source of concern because of the low base (the stock of credit to non-government was equivalent to 10 percent of GDP at end-2001), and that the bias in favor of foreign-currency-denominated lending would be reduced by the recent interest rate cuts and the unification of reserve requirements. The NBR, nevertheless, tightened supervision over the banks with the highest credit expansion, and intends to conduct more frequent on-site inspections of these banks. Furthermore, the Bank will approve a new regulation on loan provisions in August, which requires that provisions be determined on the basis of the borrower's overall financial performance, rather than only credit history, in line with international best practices. As another measure to contain lending in foreign exchange, the staff supported the NBR's decision to impose reserve requirements on foreign currency liabilities with maturities between one and two years. Staff also advised the NBR to consider other measures to reduce risks related to foreign-currency-denominated lending, including by imposing higher capital requirements for heavily exposed banks.

39. New regulations will allow full tax deductibility of bad loan provisions. Despite initial concerns about the revenue effects of this measure, the government decision on the tax deductibility of provisions was approved in late July. 


\section{E. Privatization}

40. The authorities agreed that there was a need to facilitate faster and more transparent privatization, in line with Fund and World Bank staff recommendations. As tax arrears have been a major obstacle to privatization, a new law approved in April allows such arrears accrued up to end-2001 to be written off at the moment of privatization. To address the problem of excessive employment and investment requirements imposed on investors, the authorities reduced the weight of nonprice factors in the criteria for selecting winners in privatization bids (SMEFP, 125). They also committed themselves not to grant diseretionary tax incentives, including in the context of privatization (to be monitored through a continuous structural benchmark).

\section{Efforts to complete a large number of privatization projects will be}

reinvigorated. After missing several benchmarks, the government now expects to sell eight companies with more than 1,000 employees in the July-September period. In the case of four large loss-makers, the authorities adopted a detailed timetable for splitting these companies into parts, reducing their cmployment, offering them for sale, and implementing further measures if the attempted sale is unsuccessful. For the largest state-owned company, Petrom, the government is committed to hiring a privatization advisor by mid-October, and to approving the privatization strategy by end-December 2002. (For the privatization of utilities, see paragraph 36 above.)

42. Discussions on the privatization of the largest bank, BCR, focused on setting an appropriate timetable. After the long delay in appointing a new privatization advisor, the authorities proposed a number of intermediate steps to ensure rapid progress of this important project (SMEFP, -28). Based on the understanding reached on these steps, the staff supports the authorities' request to postpone the deadline for completing the sale to a strategic investor from end-December 2002 (structural PC) to end-February 2003. Progress in the privatization of BCR will be subject to special attention in the context of the third review under the SBA.

\section{Medium-Term Outlook, External Vulnerability, and Capacity to Repay THE FUND}

43. The medium-term outlook has not changed since the approval of the program, and Romania's external vulnerability is relatively low in the short term. Official reserves have returned to a comfortable level in terms of import coverage and broad money, and currently exceed short-term debt by remaining maturity (Table 8). Market sentiment also remains relatively favorable and the recent emerging market turmoil has had limited impact. However, sustained long-term capital inflows, and particularly foreign direct investment, will be essential to maintain external viability over the medium term. While the less favorable economic outlook for Romania's major trading partners has had no visible impact on exports so far, it may marginally affect growth and exports in 2003.

44. Romania's capacity to repay the Fund remains good. Over the medium term, debt service to the Fund, including that on prospective purchases would be moderate, averaging 0.8 percent of exports of goods and nonfactor services (Table 9). The medium-term public 
debt-service profile is fairly smooth, though with some quarterly peaks due to maturing bond obligations.

\section{A full safeguards assessment of the NBR has been completed. The NBR has} indicated that initiatives are underway to remedy the identified weaknesses. In particular, staff recommended that (i) the NBR ensure the integrity of economic data provided to the Fund through establishment of reconciliation procedures; and (ii) the NBR strengthen certain internal controls and demonstrate the progress made in implementing the related initiatives already underway. Measures to this end will be incorporated into the program after being discussed with the authorities in the context of the third review under the SBA.

\section{Program Monitoring}

46. Reviews will continue to be quarterly, but purchases are being rephased, with the third review based on the end-September test date. Quarterly performance criteria are proposed for end-September and end-December 2002, and structural performance criteria and benchmarks are proposed through end-February 2003. Several structural benchmarks have been added to the program, which are aimed at supporting accelerated privatization (Box 2). With priority being given to improving collections in the energy sector, several quantitative indicative targets have been introduced in this area in addition to the existing performance criteria. Correspondingly, the indicative target on arrears to the general government has been removed, although monitoring of these arrears will continue informally. Prior actions, which comprise corrective measures for slippages under the program, are specified in Table 2 of the SMEFP.

\section{Box 2. Romania--Structural Conditionality}

A comprehensive description of the structural conditionality in the current progran and its relationship with the conditionality under the World Bank's PSAL II program can be found in EBS/01/175, p.22. In the context of the first and second reviews, the conditionality was modified to address slippages under the program in the areas of wage policy, energy scctor reform, privatization, and tax policy.

Regarding wage policy, the government approved, as prior actions, quarterly ceilings for the wage bill and employment in monitored state-owned companies, implemented about 5,000 layoffs, and issued ministerial orders to cut bonus payments in the third quarter of 2002 . The approval of the 2003 budgets of the state-owned companies in line with the agreed wage policy became a structural PC.

To improve the collection performance of the main utilities, as prior actions the government implementcd a plan to discontinue energy supplics to the industrial users with the weakest payment records, and transferred 16 heatproducing units to the local authorities.

As structural benchmarks on the privatization of companies with more than 1,000 employees were not met, revised benchmarks address the need to downsize the still very large state-owned sector with a view to ensuring the medium-term sustainability of growth. Following substantial delays in hiring a new privatization advisor for the privatization of the largest bank, BCR, the authorities requested that the structural PC be modified to envisage the completion of this privatization by end-February 2003 , instead of by end-December 2002 . As a prior action, the contract with a new privatization advisor has becn signed in May.

In addition, a new regulation on loan provisioning and a concomitant government decision on the taxation of 
these provisions were approved as a prior action with a view to moderating the recent strong growth in foreigncurrency denominated credit.

Following delays in approving the new VAT and profit tax laws, which were originally scheduled to become effective on January 1,2002 , both laws were approved as prior actions and entered into force on June 1, 2002, and July 1, 2002, respectively. Moreover, to address the revenue shortfall that significantly increased the risk for achieving the budget deficit target in 2002, the authorities increased, as a prior action, excise taxes and eliminated the excise tax exemption for producers of cigarettes using domestic tobacco.

\section{Staff APPRAISAL}

47. The authorities have so far achieved the main macroeconomic objectives of the program supported by the Stand-By Arrangement; these results now need to be consolidated and sustained. The program was designed with a view to reducing inflation while preserving growth; containing the current account deficit; and strengthening official reserves. In these areas, the program is producing its intended results. However, progress has been less satisfactory with respect to establishing firm wage discipline in state-owned enterprises, reducing the quasi-fiscal deficit in the energy sector, and accelerating privatization. In these areas, commitments under the program have not been fully realized, increasing the risk that the achieved results could be derailed and accession to the EU slowed.

\section{Improved wage discipline in state-owned enterprises, almost all of which are} loss-makers, remains of crucial importance. The nonobservance of the program targets for state enterprise wages, which have again outpaced those in the private sector, and the recent unexpected agreement on the minimum wage, which was reached outside the regular cycle of negotiations on collective contracts, confirm that policy implementation in this area remains inconsistent and weak. Persistent vigilance in delivering program targets is therefore critical both as regards containing the wider public sector deficit and enabling the NBR to pursue disinflation without undue risks to competitiveness. This holds particularly for the timely implementation of all agreed measures to ensure that the minimum wage hike in early 2003 does not translate into an overall wage increase in state-owned enterprises.

49. The government has succeeded in reducing losses in the energy sector, but weak collections remain a problem. Overall losses in the energy sector, at about 3 percent of GDP in 2002, remain large, and intensified efforts are needed to address them. The implementation of the authorities' action plan to enforce payments and disconnect supplies to large nonpayers is crucial to achieving this objective, as is determined progress with the privatization of the gas and electricity distribution companies.

\section{Following the large reduction in social security taxes, bold measures are} required to rationalize expenditure and enhance the efficiency of the tax system. Key elements in this respect are a reduction in subsidies, a containment of wage expenditure, and a review of the efficiency and affordability of transfers. On the revenue side, a vigorous implementation of the tax administration reform will help to improve revenue performance 
over time. In the same vein, it is impcrative that the authorities refrain from granting tax incentives, including a reduced VAT rate.

51. Monetary policy is appropriately focused on reducing inflation while seeking to avoid an unsustainable real effective appreciation of the leu. With improved confidence and the slowdown in aggregate demand, further interest rate cuts should be possible, and even necessary if the alternative could lead to an unsustainable real effective appreciation. In the same vein, the current policy of sterilizing inflows to avoid upward pressures on the exchange rate is appropriate.

52. Banking supervision should address the issue of the continuing rapid expansion of foreign-currency-denominated credit. In this respect, the recent modifications of the regulation on required reserves are welcome, and the new regulation on loan provisions should bave a moderating impact. Further strengthening of the prudential ratios for foreign currency loans would also be appropriate.

53. Both the speed and transparency of privatization need to improve, including in the energy sector. The proposed measures, if consistently implemented, will facilitate progress in this area. Moreover, it is essential for the government to change its overall attitude toward privatization, and to avoid imposing conditions to preserve employment or rapidly increase investment in privatized companies. The authorities would be well advised to be more decisive in liquidating perennial loss-makers.

54. Credible progress in the privatization of BCR will be of crucial importance for completing the third review. Keeping the process fully transparent and on track will provide an important signal to investors about the government's efforts to improve the investment climate. This would also be an important signal in attracting future FDI and maintaining low external vulnerability. Therefore, strict adherance to the timetable outlined in $q 28$ of the SMEFP is important.

55. The staff considers that the government's revised program deserves support. The government has confirmed its commitment to the program through the adoption of important corrective measures. Specifically, all prior actions proposed during the missions in March and July have been completed. The staff therefore recommends the approval of the waivers and the modification of the performance criterion, as well as the completion of the first and second reviews 
Table 1, Romania: Main Economic Indicators, 1999-2003

\begin{tabular}{|c|c|c|c|c|c|c|}
\hline & \multirow[t]{2}{*}{1999} & \multirow[t]{2}{*}{2000} & \multirow[t]{2}{*}{2001} & \multicolumn{2}{|c|}{2002} & \multirow{2}{*}{$\frac{2003}{\text { Projections }}$} \\
\hline & & & & Ptogram & Projections & \\
\hline \multicolumn{7}{|l|}{ Real economy (change in percent) $1 /$} \\
\hline Real GDP & $-1,2$ & 1.8 & 5.3 & 5.0 & 4.3 & 4.9 \\
\hline CPI (end of period) & 54.8 & 40.7 & 30.3 & 22.0 & 22.0 & 15.0 \\
\hline CPI (period average) & 45.8 & 45.7 & 34.5 & 26.0 & 24.2 & 19.1 \\
\hline Unemployment rate (end of period; percent) & 11.8 & 10.5 & 8.6 & 8.0 & 11.0 & 10.0 \\
\hline Gross national saving (percent of GDP) & 12.0 & 15.8 & 16.0 & 14.1 & 16.8 & 18.2 \\
\hline Gross domestic investment (percent of GDP) & 16.1 & 19.7 & 21.9 & 19.7 & 22.0 & 23.1 \\
\hline \multicolumn{7}{|l|}{ Public finance (genetal governtent, pencent of GDP) } \\
\hline Overall balance & -3.6 & -4.0 & -3.3 & -2.92 & -2.9 & -2.65 \\
\hline Primary balance & 2,4 & 0.9 & 0.6 & 0.8 & 0.4 & 0.4 \\
\hline Total public debt (in percent of GDF) $3 /$ & 27.0 & 26.3 & 25.8 & + & $\cdots$ & ... \\
\hline \multicolumn{7}{|l|}{ Money and credit (end of year, percent change) } \\
\hline Real domestic credit $4 /$ & -9.2 & 7.4 & 26.0 & 9.5 & 31.4 & $\ldots$ \\
\hline Broad money & 44.9 & 38.0 & 46.2 & 28.3 & 29.5 & $\cdots$ \\
\hline \multicolumn{7}{|l|}{ Interest rates (percent) } \\
\hline NBR interest rates (end of period) $5 /$ & 88.7 & 60.1 & 39.9 & $\ldots$ & ... & $\ldots$ \\
\hline Treasury bill rate (pcriod average) & 99.9 & 59.4 & 46.7 & $\ldots$ & $\ldots$ & $\ldots$ \\
\hline \multicolumn{7}{|l|}{ Balance of payments (peacent of GDP) } \\
\hline Trade balance & -3.5 & -4.6 & -7.5 & $-7,4$ & -7.1 & -6.8 \\
\hline Current account balance & -4.0 & -3.9 & -5.9 & -5.6 & -5.1 & -4.9 \\
\hline Officjal reserves (end-year, US\$ million) & 2,472 & 3,396 & 4,880 & $5,038.0$ & $5,950,0$ & $6,999.0$ \\
\hline Reserve covet (thonths of ituports of GNTS) & 2.1 & 2.5 & 3.3 & 3.2 & 3.7 & 4.1 \\
\hline \multicolumn{7}{|l|}{ Exchange rate } \\
\hline \multicolumn{7}{|l|}{ Exchange rate regime } \\
\hline Lei per US\$ (cud of period) & 18,250 & 25,926 & 31,597 & $\ldots$ & $\ldots$ & $\ldots$ \\
\hline NEER appreciation $(+)$ (annial average in pereent) & -39.8 & -22.8 & -22.6 & $\ldots$ & $\ldots$ & $\ldots$ \\
\hline REER appreciation (+) (CPI-based, anthal average in percent) & -14.8 & 9.5 & 1.5 & $\ldots$ & $\ldots$ & ... \\
\hline
\end{tabular}

Sounces: Rornanian authorities; and Fund stafí estimates.

1/ In 2002, national accounts data starting 1998 have been Tevisod due to methodological change (adoption of ESA95 guidelines).

2f The original target. for the nominal budget deficit was cquivalent to 3.0 percent of GDP. The upward revision of the nominal GDP was reflected in a bower deficit target in terns of GDP.

$3 /$ Incheding domestic publie debt atsd external public dcbu (public and publicly guaranted).

$4 /$ Crodil to nongovernment sector. From 1999 onwards - weighted average of real lei credit growth and U.S. dollar-measured foreign currency credit growth.

5/ NBR deposit auction interest rate. 
Table 2. Romania: Balance of Payments, 2000-02 (th millions of U.S. dollars)

\begin{tabular}{|c|c|c|c|c|c|c|c|c|c|}
\hline & \multirow{2}{*}{$\frac{2000}{\text { Act }}$} & \multicolumn{2}{|c|}{2001} & \multicolumn{6}{|c|}{2002} \\
\hline & & Acc. & Pmg. & $\begin{array}{r}Q 1 \\
P r o j \\
\end{array}$ & $\begin{array}{r}Q 2 \\
\text { Proj. } \\
\end{array}$ & $\begin{array}{r}Q 3 \\
\text { Praj. } \\
\end{array}$ & $\begin{array}{r}Q 4 \\
\text { Pnj. } \\
\end{array}$ & Pnj. & Prog. \\
\hline Current aecount & $.1,435$ & $-2,349$ & $-2,295$ & -245 & -492 & -491 & $-1,011$ & $\cdot 2,283$ & $-2,294$ \\
\hline Ratio to anmual GDP & -3.9 & -5.9 & -6.9 & -0.5 & -1.1 & -1.1 & -2.3 & -5.1 & -5.6 \\
\hline Trade balance & .1 .684 & -2.969 & -2.781 & -473 & -673 & -750 & -1.268 & $-3,164$ & $-3,0.39$ \\
\hline Exports & 10,366 & $1\}, 385$ & $11,8] 9$ & 2,990 & 3,317 & 2,981 & 2,967 & 12,165 & 12,699 \\
\hline Imports & $-12,050$ & $-14,354$ & $-14,600$ & $-3,373$ & $-3,990$ & $-3,731$ & $-4,235$ & $-15,328$ & $-15,738$ \\
\hline Services aecoutch, net & -611 & -555 & -465 & -71 & -153 & -5 & -139 & -412 & -433 \\
\hline Recoipts & 2,020 & 2,317 & 2,288 & 579 & 634 & 727 & 742 & 2,635 & 2,587 \\
\hline Payments & $-2,631$ & $-2,872$ & $-2,753$ & -500 & -787 & -732 & -880 & $-3,047$ & $-3,020$ \\
\hline of which : Itherest, thet & -382 & -341 & -470 & -22 & -163 & -6 & +130 & -321 & -460 \\
\hline Unrequiled tuansfers (net) & 860 & 1,175 & 951 & 299 & 334 & 264 & 396 & 1,293 & 1,178 \\
\hline Capital account & 2,738 & 3,115 & 3,226 & 401 & 956 & 832 & 254 & 2,422 & 2,580 \\
\hline 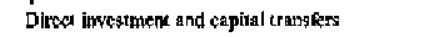 & 1,087 & 1,257 & 1,219 & 253 & 346 & 331 & 188 & 1,318 & 1,457 \\
\hline Porliólía investmenl & 50 & 70 & 110 & 2 & 10 & 10 & 20 & 42 & 50 \\
\hline Eotrowing by public sector & 882 & 1,103 & 1,401 & 17 & 420 & 399 & -88 & 748 & 673 \\
\hline Loans (nel) & 805 & 314 & 611 & 39 & 50 & 399 & -88 & 400 & 530 \\
\hline Disbursements & 1,544 & 1,337 & 1,6015 & 336 & 398 & 710 & 328 & 1,772 & 1,670 \\
\hline Of which : Dircel deb & 959 & 465 & 800 & $1 / 4$ & 126 & 462 & 23] & 933 & $84 t$ \\
\hline Of which : Gevernmenl guveranteed & 584 & B73 & 894 & 222 & 273 & 248 & 97 & 839 & 830 \\
\hline Amortizalion & -739 & $-1,023$ & -994 & -298 & -349 & -311 & -413 & $-1,573$ & $-1,140$ \\
\hline Bonds (nel) & 77 & 789 & 790 & .22 & 370 & 0 & 0 & 349 & 143 \\
\hline Disbursements & 259 & 700 & 790 & -22 & 641 & 0 & 0 & 541 & 440 \\
\hline Anortizalion & -182 & -1 & 0 & $\theta$ & -271 & 0 & 0 & -293 & $-29 ?$ \\
\hline Borruwing by privace sector (net) & 748 & 493 & 295 & 58 & 160 & 91 & -67 & 242 & 399 \\
\hline Disloursenents & 1,059 & 956 & $84 !$ & 168 & 407 & 316 & 309 & 1,200 & 1,075 \\
\hline Anortization & -311 & -463 & -546 & -111 & -247 & -225 & -376 & -958 & -676 \\
\hline Trade credit (net) & -29 & 193 & 201 & 71 & 0 & 0 & 0 & 71 & 0 \\
\hline of w shatl-1erm (net) & 5 & 188 & 200 & 62 & 0 & 0 & 0 & 62 & 0 \\
\hline Net crers and omissirns & 264 & 1,038 & 492 & -187 & -93 & -341 & 811 & 234 & 300 \\
\hline ONerall halance & 1,507 & 1,805 & 1,422 & -31 & 351 & -1 & 54 & 373 & 587 \\
\hline Financing & $-1,567$ & $-1,805$ & $-1,422$ & 31 & -351 & 1 & -54 & -373 & -587 \\
\hline Net foreiga assets NBR (increase ${ }_{1}$ ) & ${ }_{\perp 1,094}$ & $-1,809$ & $-1,484$ & -195 & -665 & -87 & -145 & $=1,092$ & .507 \\
\hline Asscts (imercasc, -) & -928 & -1.484 & $-1,021$ & -174 & -626 & -183 & -87 & $-1,070$ & -6.21 \\
\hline Liabilities & -166 & -325 & 463 & .21 & -19 & 96 & -58 & -22 & 114 \\
\hline TMF, net & 20 & -50 & -51 & $-2]$ & -39 & 96 & 42 & $7 \mathrm{~B}$ & $: 14$ \\
\hline Purchases & $\$ 15$ & 67 & 67 & 0 & 0 & 105 & 70 & 175 & 211 \\
\hline Repurchases & -95 & -117 & -118 & -21 & -39 & -10 & -28 & -98 & -97 \\
\hline Others, act & -186 & -275 & 412 & 0 & 0 & 0 & -100 & -100 & 0 \\
\hline Short-tens & -14 & 0 & -100 & 0 & 0 & 0 & -100 & -100 & 0 \\
\hline Mcdiun and long-lerm, net & -172 & -275 & .312 & 0 & 0 & 0 & 0 & 0 & 0 \\
\hline Net foreign assets DMBs (inereace, -) & -473 & 4 & 60 & 226 & 314 & 88 & 91 & 719 & -80 \\
\hline Asscis (increasc, -) & -336 & $-9 y$ & 130 & 167 & 153 & 35 & 34 & 393 & -80 \\
\hline Linbilities & -137 & 103 & -68 & 59 & 157 & 53 & 57 & 326 & 0 \\
\hline Fin由lutios gass & 0 & 0 & 0 & 0 & 0 & a & 0 & d & 0 \\
\hline \multicolumn{10}{|l|}{ Memorandurs ilems: } \\
\hline Curent actourk belanec plus FDI & -348 & $-1,092$ & $\cdot 1,075$ & $\ldots$ & $\ldots$ & $\ldots$ & $\ldots$ & -965 & -836 \\
\hline Ratio to GDP & -0.9 & -2.7 & -2.8 & $\ldots$ & $\ldots$ & $\ldots$ & ... & -1.2 & -2.0 \\
\hline Export growth (pereent) & 21.9 & 9.8 & 14.0 & 0.9 & 17.5 & 0.4 & 9.6 & 6.9 & 7.4 \\
\hline Or whick : Volune growth (percent) & 23.9 & 11.7 & 91.7 & & & & & 6.8 & 7,4 \\
\hline Import growith (perterit) & 23.7 & 19.1 & $2] .2$ & $-\mathbf{I . 1}$ & 6.8 & 12.8 & 8.6 & 6.8 & 7.8 \\
\hline Of which : Volume growth (pereent) & 29.1 & 23.9 & 16.0 & $\ldots$ & $\ldots$ & $\ldots$ & $\ldots$ & 8.5 & 7.1 \\
\hline Terms of trade (percentage thange) & 2.7 & 2.3 & -2.3 & $\ldots$ & $\ldots$ & $\ldots$ & $\ldots$ & 0.9 & -0.6 \\
\hline Extersal debd (US\$) & $10_{2} 235$ & 11,539 & 11,220 & $\ldots$ & $\ldots$ & $\ldots$ & $\ldots$ & 12,530 & 12,407 \\
\hline Of which: Public and publicdy guaranteed & 6,955 & 7,694 & 7,874 & $\ldots$ & $\ldots$ & $\ldots$ & $\ldots$ & 8,420 & 8,661 \\
\hline External debtGGP (pereenl) & 27.7 & 29.1 & 29.5 & $\ldots$ & $\ldots$ & $\ldots$ & $\ldots$ & 28.0 & 30.4 \\
\hline Debl service (US\$) & 2,046 & 2,462 & 2,814 & $\ldots$ & $\ldots$ & $\ldots$ & $\ldots$ & 3,574 & 3,070 \\
\hline Debt senice ratio & 16.9 & 18.5 & 19.9 & $\ldots$ & $\ldots$ & $\ldots$ & $\ldots$ & 25.1 & 20.1 \\
\hline Gross official reserves of the NBR $z$ & 3,396 & 4,880 & 4,417 & $\ldots$ & $\ldots$ & $\ldots$ & $\ldots$ & 5,954 & 5,038 \\
\hline (in monibs of inports of goods and services) & 2.5 & 3.3 & 3.0 & $\ldots$ & $\ldots$ & $\ldots$ & $\ldots$ & 3.7 & 3.2 \\
\hline (as percent of shon-term debt? & 179.0 & 155.9 & 165.7 & $\ldots$ & $\ldots$ & $\cdots$ & $\ldots$ & 175.3 & 183.4 \\
\hline Net exiema) linancing of the budget (US\$ culn) & 890 & 882 & 1.078 & $\ldots$ & $\ldots$ & $\ldots$ & $\ldots$ & 663 & 711 \\
\hline Noninal GDP (US\$ bin) & 36.9 & 35.7 & 38.0 & $\ldots$ & $\ldots$ & $\ldots$ & $\ldots$ & 44.7 & 40.8 \\
\hline
\end{tabular}

Sources: Romanian authorities; and Fund staff estimal es.

1) Including public ent eтprises.

2f Includes gold. 
Table 3. Romania: Summary of Consolidated General Government, 1999-2003

\begin{tabular}{|c|c|c|c|c|c|c|c|c|c|c|c|c|c|c|}
\hline & \multirow{2}{*}{$\begin{array}{l}1999 \\
\text { Actual }\end{array}$} & \multirow{2}{*}{$\begin{array}{c}2000 \\
\text { Actual }\end{array}$} & \multirow{2}{*}{$\begin{array}{l}2001 \\
\text { Actual }\end{array}$} & \multicolumn{3}{|c|}{2002} & \multirow{2}{*}{$\begin{array}{c}2003 \\
\text { Slafr } \\
\text { Estimate } \\
\text { 31-Jul-02 } \\
\end{array}$} & \multirow{2}{*}{$\begin{array}{c}1999 \\
\text { Actual }\end{array}$} & \multirow{2}{*}{$\begin{array}{c}2000 \\
\text { Actual }\end{array}$} & \multirow{2}{*}{$\begin{array}{c}2001 \\
\text { Aclual }\end{array}$} & \multicolumn{3}{|c|}{2002} & \multirow{2}{*}{$\begin{array}{c}2003 \\
\text { Staff } \\
\text { Estimate } \\
\text { 31-Jul-02 }\end{array}$} \\
\hline & & & & $\begin{array}{c}\text { Budget } \\
\text { Rer. GDP } \\
\text { 11-Nov-01 } \\
\end{array}$ & $\begin{array}{c}\text { Supplent. } \\
\text { Budget } \\
\text { 31-Jul-02 }\end{array}$ & $\begin{array}{c}\text { Staff } \\
\text { Estimase } \\
\text { 31-Jul-02 } \\
\end{array}$ & & & & & $\begin{array}{c}\text { Budget } \\
\text { Rev. GDP } \\
\text { 11-Nov-01 } \\
\end{array}$ & $\begin{array}{c}\text { Suppleñ } \\
\text { Budget } \\
\text { 31-Jul-D2 }\end{array}$ & $\begin{array}{c}\text { Staff } \\
\text { Estimate } \\
\text { 31-Jul-0z } \\
\end{array}$ & \\
\hline & \multicolumn{7}{|c|}{ (in billions lei) } & \multicolumn{7}{|c|}{ (th percent of GDP) } \\
\hline Total revenue and grants & 173,838 & 251,095 & 351,702 & 458,301 & 458,301 & 453,180 & 554,730 & 31.9 & 31.4 & 30.5 & 30.5 & 30.5 & 30.2 & 29.6 \\
\hline Current & 173,337 & 249,945 & 351,069 & $457, \$ 45$ & 457,315 & $452,1,94$ & 548,743 & 31.8 & 31.2 & 30.4 & 30.5 & 30.5 & 30.1 & 29.3 \\
\hline Tax & 164,026 & 235,048 & 327,124 & 431,918 & 426,881 & 423,082 & 516,213 & 30.1 & 29.4 & 28.3 & 28.8 & 28.4 & 28.2 & 27.5 \\
\hline Prolits & 17,037 & 20,334 & 22,206 & 33,205 & 30,668 & 29,678 & 40,046 & 3.1 & 2.5 & 1.9 & 2.2 & 2.0 & 2.0 & 2.1 \\
\hline Wages and salaries $1 t$ & 17,834 & 26,998 & 37,197 & 44,363 & 45,149 & 45,254 & 59,393 & 3.3 & 3.4 & 3.2 & 3.0 & 3.0 & 3.0 & 3.2 \\
\hline Social security $1 f$ & 57,667 & 86,557 & {$[25,615$} & 174,108 & 168,320 & 168,320 & 194,233 & 10.6 & 10.8 & 10.9 & 11.6 & 11.2 & 31.2 & 10.4 \\
\hline Other direct taxs & 8,276 & 10,059 & 13,025 & 11,612 & 12,717 & 14,310 & 15,417 & 1.5 & 2.3 & 1.1 & 0.8 & 0.8 & 1.0 & 0,8 \\
\hline VAT & 32,471 & 50,439 & 73,604 & 93,382 & 98,303 & 97,990 & 124,572 & 6.0 & 6.3 & 6.4 & 6.2 & 6.5 & 6.5 & 6.6 \\
\hline Customs & 7,847 & 8,702 & 9,038 & 9,506 & 8,501 & 8,452 & 8,109 & 1.4 & 1.1 & 0.8 & 0.6 & 0.6 & 0.6 & 0.4 \\
\hline Excise & 16,958 & 18,701 & 27,293 & 38,252 & 37,114 & 32,971 & 43,880 & 3.1 & 2.3 & 2.4 & 2.5 & 2.5 & 2.2 & 2.3 \\
\hline Other indirect taxes & 5,937 & 13,258 & 19,146 & 27,490 & 26,109 & 26,109 & 30.562 & 1.1 & 1.7 & 1.7 & 1.8 & 1.7 & 1.7 & L.6 \\
\hline Nontax & 9,311 & 14,897 & 23,945 & 25,627 & 30,434 & 29,112 & 32,530 & 1.7 & 1.9 & 2.1 & 1.7 & 2.0 & 1.9 & 1.7 \\
\hline Capital & 297 & 826 & 386 & 349 & 579 & 579 & 438 & 0.1 & 0.1 & 0.0 & 0.0 & 0.0 & 0.0 & 0.0 \\
\hline Grants & 204 & 325 & 246 & 407 & 407 & 407 & 5,549 & 0.0 & 0.0 & 0.0 & 0.0 & 0.0 & 0.0 & 0.3 \\
\hline Total expenditure & 193,567 & 283,351 & 390,317 & 501,501 & 501,501 & 496,381 & 604,439 & 35.5 & 35.4 & 33.8 & 33.4 & 33.4 & 33.1 & 32.2 \\
\hline Cutrent & 177,835 & 255,276 & 352,301 & 450,725 & 449,453 & 445,351 & 536,252 & 32.6 & 31.9 & 30.5 & 30.0 & 29.9 & 29.7 & 28.6 \\
\hline Wages and salaries & 26,259 & 43,894 & 58,189 & 74,301 & 74,463 & 74,449 & 89,433 & 4.8 & 5.5 & 5.0 & 5.0 & 5.0 & 5.0 & 4.8 \\
\hline Materials and operating expenditures & 57,504 & 56,292 & 81,122 & 94,453 & 102,574 & 101,401 & 119,905 & 10.5 & 7.0 & 7.0 & 6.6 & 6.8 & 6.8 & 6.4 \\
\hline$a / w:$ health insurance find & 22,597 & 24,997 & 36,779 & 46,794 & 47,294 & 47,294 & 60,022 & 4.1 & 3.1 & 3.2 & 3.1 & 3.2 & 3.2 & 3.2 \\
\hline Interest & 28,796 & 38,973 & 45,375 & 54,604 & 50,191 & $49_{r} 170$ & 58,051 & 5.3 & 4.9 & 3.9 & 3.6 & 3.3 & 3.3 & 3.1 \\
\hline Subsidies and transfers & 80,239 & 115,905 & 167,615 & 221,006 & 221,590 & 219,757 & 264,511 & 14.7 & 14.5 & 14.5 & 14.7 & 14.8 & 14.6 & ]4.1 \\
\hline Subşidics & 9,303 & 17,581 & 24,299 & 25,895 & 27,226 & 26,441 & 24,384 & 1.7 & 2.2 & 2.1 & 1.7 & 1.8 & 1.8 & 1.3 \\
\hline Transfers & 70,936 & 98,324 & 143,316 & 195,112 & 194,364 & 193,316 & 240,127 & 13.0 & 12.3 & 12,4 & 13.0 & 12.9 & 12.9 & 12.8 \\
\hline of $\mathrm{h}$ : Pensions & 37,854 & 53,579 & 79,578 & 108,047 & 108,047 & 107,047 & 135,000 & 6.9 & 6.7 & 6.9 & 7.2 & 7.2 & 7.1 & 7.2 \\
\hline Capital & 15,015 & 24,482 & 37,015 & 49,664 & 50,776 & 49,757 & 65,649 & 2.8 & 3.1 & 3.2 & 3.3 & 3.4 & 3.3 & 3.5 \\
\hline Lending rrinus repayments & 717 & 3,594 & 1,002 & 1,113 & 1,273 & 1,273 & 2,538 & 0.1 & 0.4 & 0.1 & 0.1 & 0.1 & 0.1 & 0.1 \\
\hline Overall belance (cash, including grants) & $-19,729$ & $-32,256$ & $-38,615$ & $-43,200$ & -43.200 & $-43,200$ & $-49,710$ & -3.6 & -4.0 & $-3,3$ & -2.9 & -2.9 & -2.9 & $-2,65$ \\
\hline Financing & 18,080 & 28,322 & 30,157 & 43,200 & 43,200 & 43,200 & 49,710 & 3.3 & 3.5 & 2.6 & 2.9 & 2.9 & 2.9 & 2.7 \\
\hline Domestic & 8,614 & $-1,913$ & $-2,347$ & 13,413 & 10,814 & 13,616 & 14,808 & 1.6 & -0.2 & -0.2 & 0.9 & 0.7 & 0.9 & 0.8 \\
\hline Extenna & 2,360 & 22,575 & 26,390 & 25,767 & 23,484 & 23,484 & 27,501 & 0.4 & 2.8 & 2.3 & 1.7 & 1.6 & 1.6 & 1.5 \\
\hline Privatization proceeds & 6,859 & 5,062 & 3,460 & 2,220 & 6,802 & 4,600 & 5,500 & 1.3 & 0.6 & 0.3 & 0.1 & 0.5 & 0.3 & 0.3 \\
\hline Bank asset recoveries & 247 & 2,597 & 2,654 & 1,800 & 2,100 & 2,100 & 1,900 & 0.0 & 0.3 & 0.2 & 0.1 & 0.1 & 0.1 & 0.1 \\
\hline Discrepancy 2f & $-1,649$ & $-3,934$ & $-8,458$ & 0 & o & 0 & 0 & -0.3 & -0.5 & -0.7 & 0.0 & 0.0 & 0.0 & 0.0 \\
\hline \multicolumn{15}{|l|}{ Memorandurn items: } \\
\hline Prinary expenditure $3 /$ & 160,956 & 244,167 & 344,942 & 446,898 & 451,311 & 447,211 & 546,388 & 29,5 & 30.5 & 29.9 & 29.8 & 30.1 & 29.8 & 29.1 \\
\hline Primary balance (cast, including grants) it & 12,883 & 6,928 & 6,760 & 11,404 & 6,991 & 5,969 & 8,342 & 2,4 & 0.9 & 0.6 & 0.8 & 0.5 & 0.4 & 0.4 \\
\hline Nomina] GDP (billions lei) & 545.730 & 800,308 & $1,154,126$ & $1,500,963$ & $1,500,963$ & $1,500,963$ & $1,875,696$ & 545,730 & 800,308 & $1,154,126$ & $1,500,963$ & $1,500,963$ & $1,500,963$ & $1,875,696$ \\
\hline
\end{tabular}

Sourees: Ministry of Public Finanec; and Fund staff estimates.

1/ 1999 getual values adjusted fur the collections of health contributions (3,484. 5 and 10,483.2 billion lei, respectively) which were previously classified as wage taxes under the program.

2/ Overall balance (cast, including grants) plus fithaticing.

3/ Excliding cash expenditure for bank restructuring.

CInternational Monetary Fund. Not for Redistribution 
Table 4. Romania: Monetary Survey, 2000-02

(tha billions of lei, current exchange rates)

\begin{tabular}{|c|c|c|c|c|c|c|c|c|c|c|c|c|}
\hline & \multirow{3}{*}{$\frac{2000}{2}$} & \multicolumn{7}{|c|}{2001} & \multicolumn{4}{|c|}{2502} \\
\hline & & \multirow[b]{2}{*}{ Mand } & \multirow[b]{2}{*}{ June } & \multirow[b]{2}{*}{$\begin{array}{c}\text { Septembor } \\
\text { program }\end{array}$} & \multirow[b]{2}{*}{$\begin{array}{c}\begin{array}{c}\text { September } \\
\text { actual }\end{array} \\
\end{array}$} & \multirow[b]{2}{*}{$\begin{array}{l}\text { Dexerribur } \\
\text { [nogramn. }\end{array}$} & \multirow[b]{2}{*}{$\begin{array}{c}\text { Decusubet } \\
\text { actual }\end{array}$} & \multirow{2}{*}{$\begin{array}{l}\text { Program } \\
\text { March } \\
\text { pragram }\end{array}$} & \multirow[b]{2}{*}{$\begin{array}{l}\text { Marcb } \\
\text { actulal }\end{array}$} & \multirow[b]{2}{*}{$\begin{array}{c}\text { June } \\
\text { rev, proggam } \\
\end{array}$} & \multirow[b]{2}{*}{$\begin{array}{c}\text { September } \\
\text { efv, program }\end{array}$} & \\
\hline & & & & & & & & & & & & $\begin{array}{c}\text { December } \\
\text { rev. program }\end{array}$ \\
\hline \multicolumn{13}{|l|}{ Mnnetary Survey } \\
\hline Net forelgn assets (Jnchuding yaluation changes) & 92,022 & 108,004 & 136,087 & 146,192 & 155,922 & 159,279 & 171,866 & 169,197 & 178,368 & 197,000 & 202,910 & 210,913 \\
\hline In millions of U,S, dollars & 3,549 & 3,918 & 4,667 & 4,789 & 5,118 & 4,980 & 5,439 & 5,074 & 5,424 & $\mathbf{5 , 8 8 5}$ & 5,910 & 5,955 \\
\hline Of which: Conumervial banks & 948 & 890 & 717 & 788 & 1,639 & 788 & 866 & 808 & 699 & 325 & 236 & 145 \\
\hline NHR & 2,601 & 3,028 & 3,950 & 4,001 & 4,079 & 4,192 & 4,573 & 4,266 & 4,785 & 5,560 & 5,674 & 5,810 \\
\hline Net damestic assets & $93,0.38$ & 83,547 & 72.411 & 79,152 & 79,223 & 92,958 & 98,646 & 89,724 & 96,958 & 97,110 & 108,238 & 139,350 \\
\hline Domestic aredit & 114,285 & 116,886 & 115,204 & 129,803 & 129,349 & 139,312 & 143,245 & 149,943 & 155,234 & 183,605 & $194,38 !$ & 221,535 \\
\hline Goveniment & 37,878 & 32,458 & 22,319 & 25,856 & 26,119 & 28,061 & 24,990 & 30,453 & 24,997 & 33,659 & 34,151 & 43,673 \\
\hline Of which : T-bills for bank restructuring if & 27,342 & 27,036 & 27,372 & 22,734 & 23,525 & 14,681 & 17,699 & 14,294 & 17,849 & 17,449 & 13,505 & 8.621 \\
\hline Non-goverment & 36,407 & 84,428 & 92,885 & 102,948 & 103,230 & 111,251 & 118,254 & 119,490 & 130,237 & 149,947 & 160,230 & 177,862 \\
\hline In foreign currency & 45,996 & 51,029 & 55,649 & 60,565 & 61,332 & 65,215 & 70,721 & 69,593 & 78,627 & 94,570 & $101, \$ 43$ & 111,478 \\
\hline (in thillions of U.S. dollars) & 1.774 & 1.851 & 1,908 & 1,984 & 2,013 & 2,039 & 2,238 & 2,087 & 2,391 & 2,825 & 2,966 & 3,147 \\
\hline In loi & 30,411 & 33,399 & 37,236 & $42,3,83$ & 41,898 & 46,036 & 47,533 & 49,897 & 51,610 & 55,377 & 58,388 & 66,385 \\
\hline Other items net & $-21,247$ & $-33,338$ & $-42,793$ & $-50,642$ & $-50,126$ & $-46,354$ & 44,598 & $-60,220$ & $-58,276$ & $-86,496$ & $-86,143$ & $-82,185$ \\
\hline Broad money & 185,060 & 191,551 & 208,498 & 225,353 & 235,145 & 252,237 & 270,512 & 258,921 & 275,326 & 294,110 & 311,148 & 350,263 \\
\hline Of which: Lei tenngninated (M2) & 110,204 & 108,292 & {$[18,567$} & 124,614 & 128,348 & 143,490 & $154,72 B$ & 142,875 & 157,746 & 171,241 & 183,755 & 217,429 \\
\hline Cursency in circulation & 25,742 & 23,774 & 29,645 & 31,270 & 32,645 & 34,703 & 35,635 & 31,602 & 33,416 & 36,956 & 41,741 & 46,077 \\
\hline Lei dcposits & 84,462 & 84,518 & 88,921 & 99,344 & 95,703 & 108,787 & 119,092 & 111,273 & 124,330 & 134,285 & 142,014 & 171,352 \\
\hline Foreigu currency deposits & 74,856 & 83,259 & 89,931 & 100,740 & 106,797 & 168,747 & $115: 784$ & 116,046 & 117,580 & 122,870 & 127,394 & 132,834 \\
\hline In millions of U.S. dolliars & 2,887 & 3,020 & 3,084 & 3,300 & 3,506 & 3,400 & $3,6 \times 64$ & 3,480 & 3,575 & 3,670 & 3,710 & 3,750 \\
\hline \multicolumn{13}{|l|}{ Memcrauffum iterns: $3 /$} \\
\hline Broad money (Mz) X) growth & 38.0 & 40.7 & 40.4 & 38.0 & 44.0 & 36.3 & 46.2 & 35.2 & 43.7 & 41.1 & 32.3 & 29.5 \\
\hline NPA contribution & 39.3 & 47.3 & 52.0 & 39.5 & 45.5 & 36.3 & 43.1 & 31.9 & 36.7 & 29.2 & 20.0 & 14.4 \\
\hline NDA sontribution & -1.3 & -6.6 & -11.6 & -1.5 & -1.4 & 0.0 & 3.0 & 3.2 & 7.0 & 118 & 12.3 & 15.0 \\
\hline Lei-denominated money growth (M2) & 31.8 & 27.6 & 30.5 & 31.1 & 35.0 & 30.2 & 40.4 & 31.9 & 45.7 & 44.4 & 43.2 & 40.5 \\
\hline Growth of currescy in circulation & 48.2 & 47.9 & 38.1 & 37.4 & 43.4 & 34.8 & 38.4 & 32.9 & 40.6 & 24.7 & 27.9 & 29.3 \\
\hline Real broad money growh & -1.9 & 0.3 & 3.5 & 5.4 & 9.8 & 5.7 & 12.2 & 5.6 & 14.9 & 13.7 & 7.6 & 6.1 \\
\hline Real lei-denominated money growth (M2) & -6.4 & -9.1 & -3.8 & 0.1 & 2.9 & 0.9 & 7.8 & 3.1 & 16.4 & 16.4 & 16.4 & 15.2 \\
\hline Real growth of cerrency in circulation & 5.3 & 5.4 & 1.8 & 4.9 & 9.3 & 4.5 & 6.3 & $3 . \mathrm{B}$ & 12.3 & 0.5 & 3.9 & 6.0 \\
\hline Growth of lei creadit to nongoverument, adjusted $2 /$ & $36 . \hat{9}$ & 40.4 & 51.3 & 50.6 & 49.0 & 51.4 & 56.3 & 49,4 & 54.5 & 48.7 & 39.4 & 39.7 \\
\hline Growth of lei credit to nougovenunemt, widjusted, real $2 /$ & -2.7 & 0.1 & 11.5 & 15.2 & 13.5 & 16.2 & 20.0 & 16.9 & 23.5 & 19.9 & 13.3 & 14.5 \\
\hline Growth of foreign currency dencominated credit, adjusted, in US\$ 2 & 13.7 & 16.7 & 16,5 & 28.7 & 30.3 & 18.5 & 30.1 & 12.7 & 29.2 & 48.0 & 47.3 & 40.6 \\
\hline Growth of credit to nongovennment, composite $2 / 4$ & 7.4 & 10.4 & I4.6 & 23.3 & 23.7 & [7.6 & 260 & 14.5 & 26.9 & 35.8 & 35.2 & 31.4 \\
\hline CPl inflation & 40.7 & 40.3 & 35.7 & 31.0 & 31.2 & 29.0 & 30.3 & 28.0 & 25.1 & 24.1 & 23.0 & 22.0 \\
\hline M2X (Bruad Maney) velocity & 5.0 & 5.6 & 5.5 & 5.1 & 5.1 & 4.9 & 4.8 & 5.3 & 5.1 & 5.0 & 5.0 & 4.7 \\
\hline M2 (Tomestic Broad Money) velocity & 8.4 & 9.9 & 9.6 & 9.4 & 9.4 & 8.6 & 8.4 & 9.6 & 8.9 & 8.6 & 8.4 & 2.6 \\
\hline M2X+Tbill welocity & 4.6 & 4.9 & 4.8 & 4.5 & 4.5 & 4.3 & 4.3 & 4.7 & 4.5 & 4.4 & 4.3 & 4.1 \\
\hline M2X +Tbill growth & 45.5 & 48.7 & 48.2 & 48.8 & 48.8 & 41.1 & 49.3 & 34.0 & 43.9 & 41.4 & 33.9 & 31.7 \\
\hline
\end{tabular}

Sources: Romanim authorities; and Fund stafl estivates.

1/Bonds issued to restructurc Banconex and Banca Agricola.

$2 /$ Adjusted for write-offs in the last 12 months. Owing to the large-seale write-offs and reclassifreations, credit growth rates are estimated.

$3 /$ All changes are 12 -month rates of clingige, wless otherwise inticated.

4/ Real lei credil genwth and foreign eurency credit growth, weighted by their respective shares.

CInternational Monetary Fund. Not for Redistribution 
Table 4. (continued) Romania: Balance Sheet of the National Bank, 2000-02 1/

(In billions of lei, cornent exchange rates, monthly averages)

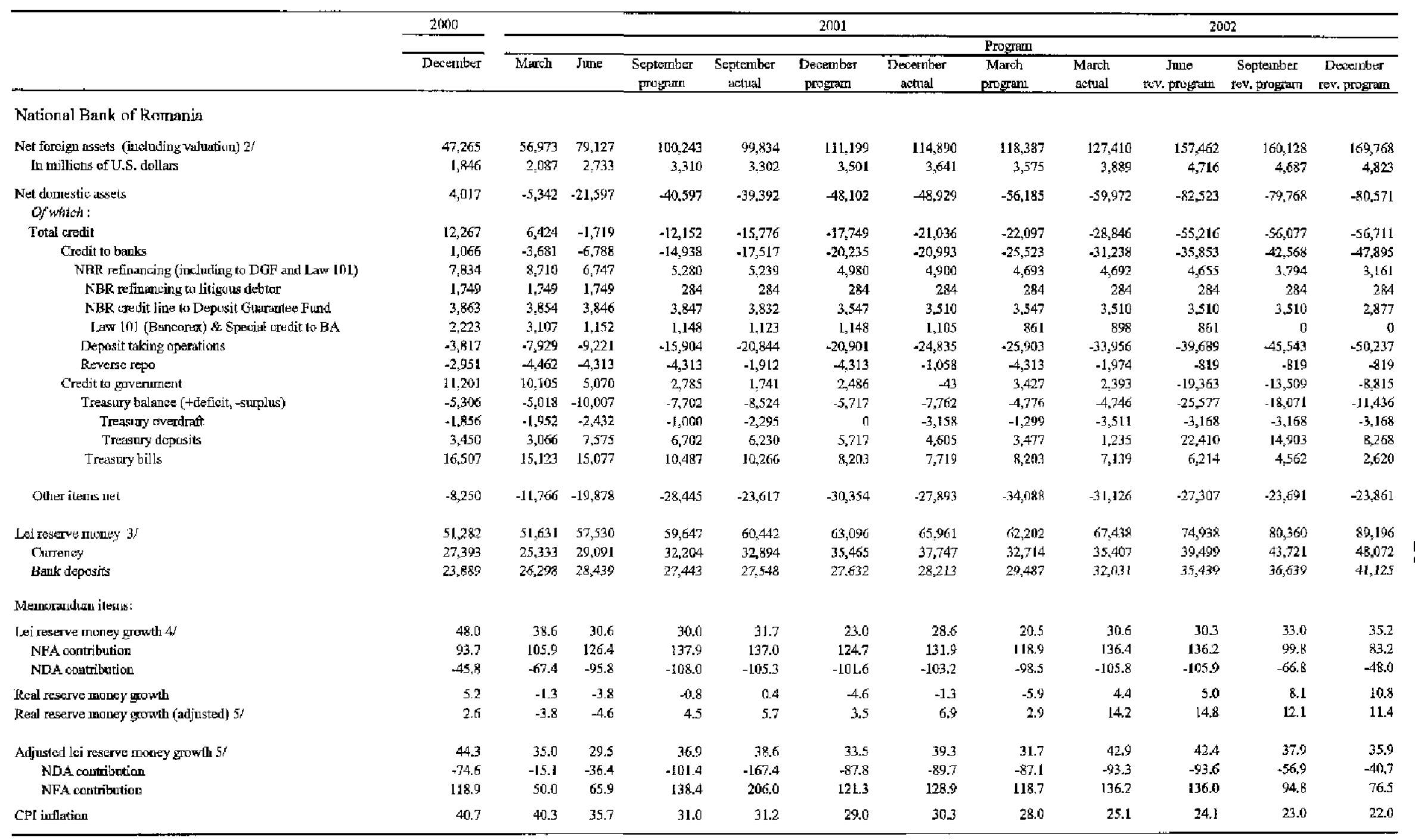

Sorrces: Rumanian anthoritics; and Fund staffestimates.

1/ Fur the program, all values are defined on a monthly average basis.

2/ Program definition excludes depositis of curnutureial bunks to meet required reserves against forrign surrency deposits. This, and the fact that the figures here arc monchly sverages, explain the diffenences from the monetary survey.

$3 /$ Indicitive targets based on xhich the NDA FC is sel.

4/ All changes are 12-month retes iI chlinge, wiless of herwise indicatted

5j Adjusted fir hoth (i) shottfalls is reported reserve maney and (ii) changes in mjinitnum rescrve requiremenls.

(i) Shortfills in reported reserve money accured in 1999 and early 2000 owimg to failme of some banks to observe the reserve re quirements and the time lag given to BCR to observe certain

transfered deposiss finm former BX in the first part of 2000. Snall deficiencies persisted throughout 2000 and $200 \mathrm{l}$ and are expected to disappear from mid-201/2 orwards.

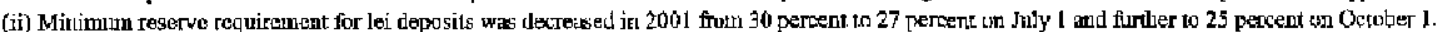

In 2002, a further cut to 22 percent became effective on Aprit] ! (not reflected in the reserve woncy figures for eimparcbility].

CInternational Monetary Fund. Not for Redistribution 
Table 5. Romania: The Quasi-Fiscal Deficit in the Energy Sector, 2000-03

\begin{tabular}{|c|c|c|c|c|c|c|c|}
\hline & 2000 & 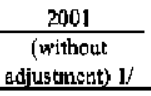 & $\frac{2001}{\text { Trogram }}$ & $\frac{200 !}{\text { Aetual }}$ & $\frac{2002}{\text { Program }}$ & $\frac{2002}{\text { Projections }}$ & $\frac{2003}{\text { Prajections }}$ \\
\hline & \multicolumn{6}{|c|}{ 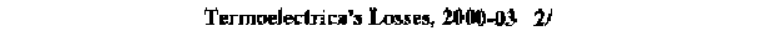 } & \\
\hline \multicolumn{8}{|l|}{ Heating } \\
\hline Cost recovery priçe (U. S. dollar/Gaal) 3/ & 22 & 20 & 20 & 20 & 20 & 19 & 19 \\
\hline Current pricess (U.S. dollav'Gcal, year-average) & 11 & 10 & 12 & 12 & 17 & 17 & 20 \\
\hline Termoelectrica's heating output sold (million Gcal) & 22 & 26 & 26 & 23 & 26 & 72 & 22 \\
\hline Temontectricst's losses froth heating (in millions of U.S. dollars) & 257 & 249 & 198 & 178 & 77 & 33 & -33 \\
\hline \multicolumn{8}{|l|}{ Electricity } \\
\hline Cosi rezivery price (U.S. dollar/Mwh) 3t & 35 & 40 & 40 & 38 & 40 & 38 & 38 \\
\hline Autual prices (U.S. dollar/Mwb, year-average) & 34 & 29 & 32 & 32 & 38 & 38 & 39 \\
\hline Termoelectrica's electricity output sold (million Mwh) & 29 & 29 & 29 & 28 & 29 & 29 & 29 \\
\hline Termoelectrica's losses fram electricfy (in millions of U.S. dollars) & 12 & 329 & 234 & 163 & 47 & 0 & .29 \\
\hline Total losses from operations (in millions of U.S. dollars) & $26 \%$ & 578 & 431 & 342 & 123 & 33 & -62 \\
\hline as jectent of GDP & 0.7 & 1.5 & 1,1 & 0.9 & 0.3 & 0.1 & -0.1 \\
\hline Collection rate (it percent) & 82 & 75 & 95 & 83 & 98 & 90 & 95 \\
\hline Losses from non-collection (in millions of U.S. dullars) & 216 & 270 & 61 & 202 & 38 & 147 & 78 \\
\hline Total losses includiting hon-colledion (ith thillions of U.S. dollars) & 485 & 848 & 493 & 543 & 162 & 180 & 16 \\
\hline \multirow[t]{2}{*}{ as pereent of GDP } & 1.3 & 2.1 & 1.2 & 1.4 & 0.4 & 0.4 & 0.0 \\
\hline & \multicolumn{6}{|c|}{ Impllelt Subsidy from Natural Gas, 2000-03 } & \\
\hline \multicolumn{8}{|l|}{ Natural Gas Produetion } \\
\hline Import price (average, U.S. dollar/cm) & 124 & 130 & 130 & 139 & 120 & 120 & 300 \\
\hline Domestic wellhend price (average, U.S. dollnt/cm) & 35 & 26 & 35 & 35 & 46 & 43 & 43 \\
\hline Donnestic output (million tem) & 14 & 14 & 14 & 13 & 14 & 13 & 13 \\
\hline Loss from low prices (in millions of U.S. dollars) & 1,249 & 1,455 & 1,327 & 1,373 & 1,025 & 1,001 & 741 \\
\hline Total supply to end-users, incl. transp. \& dis. \{in millions of U.S. dollars\} & 566 & 1,103 & 1,103 & 993 & 1,155 & 1,073 & 1170 \\
\hline Collection rate (percent) & 87 & 76 & 95 & si & 98 & 90 & 95 \\
\hline Losses from non-collection [in millions of U.S. doilars\} & 74 & 270 & ss & 189 & 2y & 107 & 51) \\
\hline Total losses and impliçit subsidy (in millions of U.S. dollars) & 1,322 & $:, 725$ & 1,382 & 1,569 & 1,054 & 1,108 & 800 \\
\hline \multirow[t]{2}{*}{ as percent of GDP } & 3.6 & 4.3 & 3.5 & 3.9 & 2.4 & 2.5 & 1.6 \\
\hline & \multicolumn{6}{|c|}{ Total for Heating, Eleetrlefty and Gas, 2000-03 } & \\
\hline Total Inpliclt Suleddles and Losses ( $\mathbf{5 m}$ ) & 1,807 & 2,573 & 1,875 & 2,105 & 1,236 & 1,288 & 816 \\
\hline as percent of GDP & 4.9 & 6.5 & 4.7 & 5.3 & 2.7 & 2.9 & L.6 \\
\hline Change relative to the previous year & $\ldots$ & 1.6 & -0.2 & 0.4 & -2.0 & -2.4 & -1.3 \\
\hline Estimated change in the savthgs - investinent balause of public enterprises 4/ & $\ldots$ & -0.5 & 0.1 & -0.1 & 0.7 & 0.8 & 0.6 \\
\hline \multicolumn{8}{|l|}{ Memoranduse item: } \\
\hline Ptogram GDP (in millions of U.S. dollars) & 36,900 & 39,721 & 39,721 & 39.721 & 44,697 & $44.69 \mathrm{~T}$ & 50,325 \\
\hline
\end{tabular}

Sources: ANRE (elsctricity tegulatory agency), Temnaelectrica and Distrigar Nord and Sud; World Bank; and Fund staff estimates

1/ Estimates, as of September 2001, based on the assumption that the adjustments as envisiged under the progtan were not inlplemented.

2/ For 2002 and 2003, Terrioekectrica's data as shown includes all externalized units.

3/ Cost recovery price estimates are based on WEO fuel price projections as of March 6, 2002.

4/ The reduction in losses only partially translates into improvement in the saving/investment balance, owing to the offiseting factots: (1) increase it losses in other public enterptises;

(ii) higher tax paymencs of the energy sector; and (iii) higher investment in the energy sector. For 2003, this effect is estimated as $1 / 2$. 
Table 6. Romania: Medium-Term Balance of Payments Outlook, 2000-06

\begin{tabular}{|c|c|c|c|c|c|c|c|}
\hline & $\begin{array}{r}2000 \\
\text { Act. }\end{array}$ & $\begin{array}{r}2001 \\
\text { Est. }\end{array}$ & $\begin{array}{l}2002 \\
\text { Proj. }\end{array}$ & $\begin{array}{l}2003 \\
\text { Proj. }\end{array}$ & $\begin{array}{l}2004 \\
\text { Proj. }\end{array}$ & $\begin{array}{l}2005 \\
\text { Proj. }\end{array}$ & $\begin{array}{l}2006 \\
\text { Proj. }\end{array}$ \\
\hline Current account & $-1,435$ & $-2,349$ & $-2,283$ & $-2,473$ & $-2,513$ & $-2,838$ & $-3,042$ \\
\hline Ratio to GDP & -3.9 & -5.9 & -5.1 & -4.9 & -4.8 & -4.7 & -4.6 \\
\hline Trade balance & $-1,684$ & $-2,969$ & $-3,164$ & $-3,433$ & $-3,658$ & $-3,911$ & $-4,160$ \\
\hline Exports & 10,366 & 11,385 & 12,165 & 13,269 & $14,4 ! 4$ & 15,627 & 16,942 \\
\hline linports & $-12,050$ & $-14,354$ & $-15,328$ & $-16,702$ & $-18,072$ & $-19,538$ & $-21,102$ \\
\hline Services account, net & -254 & -555 & -412 & -470 & -533 & -631 & -737 \\
\hline Of which: interest, net & -382 & -341 & -321 & -299 & -299 & -329 & $-36 i$ \\
\hline Unrequited transfers & 860 & 1,175 & 1,293 & 1,431 & 1,578 & 1,705 & 1,855 \\
\hline Capital account & 2,738 & 3,115 & 2,422 & 3,463 & 3,749 & 4,148 & 4,056 \\
\hline Direct invesiment and capital transfers & 1,087 & 1,257 & 1,318 & 2,010 & 1,884 & 1,840 & 1,821 \\
\hline Portfolio Investment & 50 & 70 & 42 & 50 & 50 & 50 & 50 \\
\hline Bortowing by public sector $\mathrm{I} /$ & 882 & 1,103 & 748 & 738 & 709 & 771 & 794 \\
\hline Loans (net) & 805 & 314 & 400 & 538 & 409 & 571 & 494 \\
\hline Disbursements & 1,544 & 1,337 & 1,772 & 1,746 & 1,810 & 1,801 & 1,901 \\
\hline Amortization & -739 & $-3,023$ & $-1,373$ & $-1,208$ & $-1,400$ & $-1,230$ & $-1,408$ \\
\hline Botnds (net) & 77 & 789 & 349 & 200 & 300 & 200 & 300 \\
\hline Disbursements & 259 & 790 & 641 & 340 & 441 & 624 & 584 \\
\hline Amortization & --182 & -1 & -293 & -140 & -141 & -424 & -284 \\
\hline Borrowing by private sector & 748 & 493 & 242 & 665 & 1,106 & 1,487 & 1,391 \\
\hline Disbursements & 1,059 & 956 & 1,200 & 2,012 & 2,173 & 2,282 & 2,453 \\
\hline Amortization & -311 & -463 & -958 & $-1,347$ & $-1,068$ & -795 & $-1,062$ \\
\hline Short-term (nct) & 5 & 188 & 62 & 0 & 0 & 0 & 0 \\
\hline Credit extended & -34 & 5 & 9 & 0 & 0 & 0 & 0 \\
\hline Net errors and arnmisions & 264 & $1,0,038$ & 234 & 0 & 0 & 0 & 0 \\
\hline Oyerall balance & 1,567 & 1,805 & 373 & 990 & 1,135 & 1,311 & $1,0] 4$ \\
\hline Financing & $-1,567$ & $-1,805$ & -373 & -990 & $-1,135$ & $\cdot 1,311$ & $-1,014$ \\
\hline Net foreign assets NBR (increase, -) & $-1,094$ & $-1,809$ & $-1,092$ & $-1,010$ & $-1,057$ & $-1,176$ & -768 \\
\hline Assets (increase, -) & -928 & $-1,484$ & $-1,070$ & $-1,049$ & -955 & $-1,101$ & -602 \\
\hline Liabilities & -166 & -325 & -22 & 39 & -101 & -74 & -166 \\
\hline IMF, net & 20 & -50 & 78 & 39 & -101 & -74 & -166 \\
\hline Purchases & 115 & 67 & 176 & 141 & 0 & 0 & 0 \\
\hline Repurchases & -95 & -117 & -98 & -102 & -101 & -74 & -166 \\
\hline Other, net & -186 & -275 & -100 & 0 & 0 & 0 & 0 \\
\hline Net foreign assets DMBs (inerease, -) & -473 & 4 & 719 & 20 & -79 & -135 & -246 \\
\hline Assets (increase $e_{1}$ ) & -336 & -99 & 393 & 20 & -79 & -135 & -246 \\
\hline Liabilities & -137 & 103 & 326 & 0 & 0 & 0 & 0 \\
\hline Financing gap & 0 & 0 & 0 & 0 & 0 & 0 & 0 \\
\hline Export growth (peroent) & 21.9 & 9.8 & 6.9 & 9,1 & 8.6 & 8.4 & 8.4 \\
\hline Import growth (percent) & 23.7 & 19.1 & 6.8 & 9.0 & 8.2 & 8.1 & 8.0 \\
\hline External debt/GDP (percent) & 27.7 & 29.1 & 28.0 & 27.8 & 28.5 & 29.8 & 30.3 \\
\hline Public and publicly guaranteed debt/GDP (percent) & 18.8 & 19.5 & 19.2 & 18.6 & 17.8 & 17.5 & 17.0 \\
\hline Net External Indebtedness/GDP (\%) & 14.5 & 12.7 & 12.0 & $\$ 1.5$ & 11.8 & 12.4 & 13.1 \\
\hline Debt service tatio & 16.9 & 18.5 & 25.1 & 23.4 & 21.6 & 19.5 & 20.6 \\
\hline Gross reserves of NBR (in US\$ mns.) 2/ & 3,396 & 4,880 & 5,950 & 6,999 & 7,954 & 9,056 & 9,658 \\
\hline (over shor-term debt by remaining matutity) & 179.0 & 155.9 & 175.3 & 211.6 & 254.9 & 257.5 & 275.0 \\
\hline (in monthe of imports of following year) & 2.5 & 3.3 & 3.7 & 4.1 & 4.3 & 4.5 & 4.5 \\
\hline
\end{tabular}

Sources: Romanian authorities; and Fund staff estimates.

1/ Including public enterprises.

2) Includes gold. 
Table 7. Romania: External Financing Requirements and Sources, 1999-2002 (In millions of U.S. dollars)

\begin{tabular}{|c|c|c|c|c|}
\hline & 1999 & 2000 & 2001 & $\begin{array}{l}\text { Proj. } \\
2002 \\
\end{array}$ \\
\hline 1. Gross financing requirements & 3,731 & 4,312 & 5,911 & 5,780 \\
\hline External current account deficit & 1,446 & 1,435 & 2,349 & 2,283 \\
\hline Debt amortization & 2,244 & 1,518 & 1,862 & 2,723 \\
\hline Public sector & 1,610 & 1,207 & 1,399 & 1,765 \\
\hline of which: Bonds and notes & 747 & 354 & 276 & 293 \\
\hline Private sector & 634 & 311 & 463 & 958 \\
\hline Repayment of arrears & 0 & 0 & 0 & 0 \\
\hline Gross reserves accumulation & -98 & 1,264 & 1,583 & 677 \\
\hline IMF repurchases and repayments & 139 & 95 & $1 \mathbf{1} 7$ & 98 \\
\hline 2. Available financing & 3,192 & 3,752 & 5,743 & 5,405 \\
\hline FDI and capital transfers (net) & 1,070 & 1,087 & 1,257 & 1,318 \\
\hline Public sector borrowing & 815 & 1,458 & 2,127 & 2,214 \\
\hline Loans & 815 & 1,199 & 1,337 & 1,573 \\
\hline Bonds & 0 & 259 & 790 & 641 \\
\hline Private sector borrowing & 780 & 922 & 1,059 & 1,526 \\
\hline Other flows $1 /$ & 527 & 285 & 1,301 & 347 \\
\hline Financing gap & 539 & 560 & 168 & 375 \\
\hline Balance of payments financing & 539 & 560 & 167 & 375 \\
\hline IMF & 73 & 115 & 67 & 176 \\
\hline Other $2 /$ & 466 & 445 & 100 & 200 \\
\hline Accumulation of arrears (exceptional) & 0 & 0 & 0 & 0 \\
\hline Residual financing gap & 0 & 0 & 1 & 0 \\
\hline
\end{tabular}

Sources: Romanian authorities; and Fund staff estimates.

1/ Includes all other nef financial flows, and errors and omissions.

2) Lucludes World Bank PSAL2 and EU loans. 
Table 8. Romania: Indicators of External Vulnerability, 1997-2002 1/

(In percent of GDP unless otherwise specified)

\begin{tabular}{|c|c|c|c|c|c|c|}
\hline & 1997 & 1998 & 1999 & 2000 & 2001 & $\begin{array}{r}2002 \\
\text { proj. }\end{array}$ \\
\hline \multicolumn{7}{|l|}{ Financial indicators } \\
\hline Public sector debt & 28.1 & 28.1 & 30.6 & 30.0 & 27.6 & 25.8 \\
\hline Broad money (percent change, 12-nonth basis) & 104.8 & 48.9 & 44.9 & 38.0 & 46.2 & 29.5 \\
\hline Credit to non-government (percent changc, 12-month basis) $2 /$ & 33.7 & 64.7 & 43.2 & 50.3 & 57.7 & 60.3 \\
\hline Real credit to non-government (percent change, 12 -month basis) $2 /$ & -46.9 & 17.0 & -9.2 & 7.4 & 26.0 & 31.4 \\
\hline Monthly weighted average $t-b i l l$ rate & 133.5 & 82.4 & 105.2 & 62.4 & 47.4 & $27.34 /$ \\
\hline Monthly weighted average real t-bill rate 3 / & -8.3 & 14.6 & 40.7 & 11.5 & 13.0 & $2.64 /$ \\
\hline \multicolumn{7}{|l|}{ External Indicators } \\
\hline Exports (percent change, 12-month basis in US\$) & 4,6 & -1.6 & 2.4 & 21.9 & 9.8 & 6.9 \\
\hline Imports (percent change, 12-month basis in US\$) & -1.4 & 4.8 & -12.1 & 23.7 & 19.1 & 6.8 \\
\hline Terms of Trade (percent change, 12-month basis) & 9.0 & -4.0 & 0.2 & 2.7 & 2.3 & 0.9 \\
\hline Current account balanoe & -5.4 & -7.0 & -4.1 & -3.9 & -5.9 & -5.1 \\
\hline Current account balanee after FDI & -1.9 & -2.1 & -1.2 & -0.9 & -2.7 & -2.2 \\
\hline Errors and omissions & 3.2 & 1.4 & 2.3 & 0.7 & 2.6 & 0.5 \\
\hline Gross official reserves (in US\$ millions) & 3,075 & 2,299 & 2,472 & 3,396 & 4,880 & 5,950 \\
\hline (in months of imports GNFS of the following year) & 2.9 & 2.4 & 2.1 & 2.5 & 3.3 & 3.7 \\
\hline Central Bank short-term foreign liabilities (in US\$ millions) & 100 & 0 & 170 & 100 & 100 & 0 \\
\hline Gross reserves of the banking system (in US\$ millions) & 4,763 & 3,789 & 3,633 & 4,893 & 6,476 & 7,153 \\
\hline (in months of imports GNFS of the following year) & 4.5 & 3.9 & 3.1 & 3.6 & 4.4 & 4.5 \\
\hline Short term foreign liabilities of the commercial banks (in US\$) & 267 & 188 & 221 & 225 & 371 & $5125 t$ \\
\hline Open foreign currency position of the commercial banks (in USS) & 1,400 & 1,933 & 883 & 535 & 661 & $7915 / 10 /$ \\
\hline Official reseves/Broad money (M2) & 40.3 & 27.2 & 33.6 & 47.6 & 57,0 & 60.2 \\
\hline Official reserves/Narrow noney $(\mathrm{M} 0)$ ) $6 t$ & 242.6 & 307.1 & 144.2 & 183.7 & 231.8 & 233.1 \\
\hline Total short term external debt by remaining maturity $7 /$ & 8.0 & 5.6 & 4.7 & 5.1 & 7.9 & 7.6 \\
\hline In percent of reserves & 91.8 & 118.7 & 67.8 & 55.9 & 64.1 & 57.1 \\
\hline In percent of total debt & 27.4 & 29.6 & 23.7 & 18.5 & 27.1 & 27.1 \\
\hline Total external debt (in US\$ millions) & 9,467 & 9,903 & 8,784 & 10,235 & $11,5,39$ & 12,530 \\
\hline Of which: Public and Publicly guaranteed debt & 6,855 & 7,001 & 6,169 & 6,955 & 7,694 & 8,420 \\
\hline Total external debt (in percent of exports of G\&S) & 95.1 & 104.0 & 89.0 & 84.4 & 86.5 & 87.9 \\
\hline Total external debt/ GDP & 26.9 & 23.9 & 24.9 & 27.7 & 29.1 & 28.0 \\
\hline External interest payments (in percent of exports of G\&S) & 5.0 & 5.7 & 5.1 & 4.4 & 4.4 & 5.3 \\
\hline External amortization payments (in percent of exports of G\&S) & 15.9 & 18.0 & 23.9 & 12.5 & 14.1 & 19.8 \\
\hline Exchange rate (per US\$, period average) & 7,195 & 8,881 & 15,274 & 21,688 & 29,056 & $\cdots$ \\
\hline REER appreciation $(+)$ (12-month basis) & 16.5 & 30.0 & -14.8 & 9.5 & 1.5 & $\cdots$ \\
\hline \multicolumn{7}{|l|}{ Financial Market Indicators } \\
\hline \multicolumn{7}{|l|}{ Foreign currency dcbt ratings } \\
\hline Moody's & $\mathrm{Ba3}$ & B3 & B3 & B3 & $B 2$ & $\mathbf{B 2} 8 /$ \\
\hline Standard and Poor's & BB- & B+ & B- & B- & B & $\mathrm{B}+8 /$ \\
\hline Spread of benchmark bonds (basis points, end of period) & 350 & 1,300 & 780 & 562 & 417 & $4319 /$ \\
\hline
\end{tabular}

Sources: Romanian authorities; and Fund staff estimates.

1/ All stocks are measured end-of-period.

2/ Adjusted for bad loans written off. Real credit growth is weighted average of real lei credit growth and U.S. dollar-measured foreign currency growth.

3/ Real rate is based on ex-post 12-month CPI inflation.

4/ Actual as of June 2002.

5/ Actual as of Jute 2002.

6/ Narrow money is defined as currency plus lei-denominated sight deposits.

7/ Defined as short-term debt by original maturity basis plus amortizalion falling due on medium-term loans and bonds.

8/ Actual on July 29, 2002.

9/ In 2001 the benchmark bond is the 05 , while for earlier years it is the 102 . Actual on July 22, 2002.

$10 /$ On-balance-sheet only. The overall open curnetry position, including off-balathec-sheet items, was US\$105 million as of end-June. 
Table 9. Romania: Indicators of Fund Credit, 2000-06

(In percent, unless otherwise indicated)

\begin{tabular}{|c|c|c|c|c|c|c|c|}
\hline & 2000 & 2001 & 2002 & 2003 & 2004 & 2005 & 2006 \\
\hline \multicolumn{8}{|l|}{$\begin{array}{l}\text { Outstanding Fund Credit } \\
\text { (end of period) }\end{array}$} \\
\hline In millions of SDRs & 347.9 & 308.0 & 370.3 & 400.7 & 321.7 & 263.7 & 134.4 \\
\hline In millions of U.S. dollars & 458.8 & 397.9 & 471.8 & 514.1 & 412.7 & 338.3 & 172.4 \\
\hline In percent of quota & 33.8 & 29.9 & 35.9 & 38.9 & 31.2 & 25.6 & 13.0 \\
\hline In percent of GDP & 1.2 & 1.0 & 1.1 & 1.0 & 0.8 & 0.6 & 0.3 \\
\hline In percent of exports of goods and services & 3.8 & 3.0 & 3.3 & 33 & 2.5 & 1.9 & 0.9 \\
\hline In percent of official reserves & 13.5 & 8.2 & 7.9 & 7.3 & 5.2 & 3.7 & 1.8 \\
\hline $\begin{array}{l}\text { Debt service due to the Fund } \\
\text { (in millions of U.S. dollars) }\end{array}$ & 120.3 & 118.7 & 113.4 & 121.0 & 118.4 & 88.7 & 177.2 \\
\hline In percent of quota & 11.7 & 11.5 & 11.0 & 11.7 & 11.5 & 8.6 & 17.2 \\
\hline In percent of GDP & 0.3 & 0.3 & 0.3 & 0.2 & 0.2 & 0.1 & 0.3 \\
\hline In percent of exports of goods and services & 1.0 & 0.9 & 0.8 & 0.8 & 0.7 & 0.5 & 0.9 \\
\hline In percent of official reserves & 3.5 & 2.4 & 1.9 & 1.7 & 1.5 & 1.0 & 1.8 \\
\hline
\end{tabular}

Sources: Treasurer's Department; Romanian authorities; and Fund staff calculations. 
Table 10. Romania; Medium-Term Projections, 2000-06

\begin{tabular}{|c|c|c|c|c|c|c|c|}
\hline & \multirow[t]{2}{*}{2000} & \multirow[t]{2}{*}{2001} & 2002 & 2003 & 2004 & 2005 & 2006 \\
\hline & & & \multicolumn{5}{|c|}{ Projected } \\
\hline \multicolumn{8}{|l|}{ Income and prices } \\
\hline Nominal GDP (in trillions of lei) & 800.3 & $1,154.1$ & $1,501.0$ & $1,875.2$ & $2,208.3$ & $2,497.7$ & $2,765.1$ \\
\hline Nmminal GDP (in billions of U.S. dollars) & 36.9 & 39.7 & 44.7 & 50.3 & 55.0 & 60.0 & 65.6 \\
\hline Real GDP & 1.8 & 5.3 & 4.3 & 4.9 & 5.0 & 5.0 & 5.0 \\
\hline Domestic Demand & 4.1 & 8.1 & 4.5 & 5.4 & 5.3 & 5.3 & 5.3 \\
\hline Household consurnption & -0.9 & 6.7 & 4.2 & 4.0 & 3.4 & 3.2 & 3.0 \\
\hline Government consumption & 10.4 & 1.4 & -0.2 & -0.1 & 1.8 & 2.4 & 2.8 \\
\hline Gross fixed investment & 4.6 & 6.6 & 8.1 & 9.8 & 11.1 & 12.2 & 11.9 \\
\hline of which: private & 4.3 & 6,1 & 7.5 & 9.5 & 11.0 & 12.0 & 12.0 \\
\hline of which: public & 8.8 & 11.3 & 14.5 & 12.7 & 12.4 & 14.5 & 11.4 \\
\hline Increase in stocks (contribation)* & 2.5 & 2.4 & 0.5 & 1.3 & 1.0 & 0.8 & 0.8 \\
\hline Extemal Demand (contribution) & -2.9 & -3.3 & -0.8 & $-1,1$ & -0.9 & -1.0 & -0.9 \\
\hline Expotts of goods atd services & 24.1 & 10.6 & 7.3 & 8.6 & 8.3 & 8.1 & 8.1 \\
\hline Imports of goods and serviecs & 28.2 & 17,5 & 7.3 & 9.0 & 8.2 & 8.1 & 8.0 \\
\hline GDP deflator & 44.1 & 37.0 & 24.7 & 19.1 & 12.1 & 7.7 & 5.4 \\
\hline CPL, e.o.p. & 40.7 & 30.3 & 22.0 & 15.0 & 10.0 & 6.0 & 5.0 \\
\hline CPI, p.a. & 45.7 & 34.5 & 24.2 & 19.1 & 12.1 & 7.7 & 5.4 \\
\hline \multicolumn{8}{|l|}{ Saving and Investment balances } \\
\hline Total donnstic saving & 14.5 & 13.9 & 14.7 & 16.0 & 17.3 & 18.6 & 19.8 \\
\hline Net fictor receipts and transfers from abroad & 1.4 & 2.1 & 2.1 & 2.2 & 23 & 2.3 & 2.3 \\
\hline Total national saving & 15.8 & 160 & 16.8 & 18.2 & 19.6 & 20.8 & 22.1 \\
\hline Non-govenument & 16.8 & 16.1 & 16.4 & 17.4 & 18.5 & 19.2 & 20.2 \\
\hline of which energy sector & 1.2 & 1.0 & 2.2 & 2.7 & 2.8 & 2.9 & 3.0 \\
\hline Govenment & -0.9 & -0.1 & 0.5 & 0.8 & 1.1 & 1.6 & 1.9 \\
\hline Total investment & 19.7 & 21.9 & 22,0 & 23.3 & 24.3 & 25.5 & 26.7 \\
\hline Non-government & 16.16 & 18.7 & 18.6 & 19.6 & 20.7 & 21.6 & 22.6 \\
\hline of which: energy sector & 2.7 & 2.8 & 3.0 & 3.3 & 3.2 & 3.1 & 2.8 \\
\hline Gopentument & 3.1 & 3.2 & 3.4 & 3.5 & 3.7 & 3,9 & 4.1 \\
\hline Savings - inpestruent balance & -3.9 & -5.9 & -5.1 & -4.9 & -4.8 & -4.7 & -4.6 \\
\hline Non-govenument & 0.1 & .2 .6 & -2.2 & -2.3 & -2.2 & -2.4 & -2.5 \\
\hline of which: energy sector & -1.5 & -1.8 & -0.8 & -0.6 & -0.4 & -0.2 & 0.2 \\
\hline Government & -4.0 & -3.3 & -2.9 & -2.7 & -2.6 & -2.4 & -2.2 \\
\hline
\end{tabular}

Sources: Romanian authorities; and Fund staff estimates and projections.

*Includes statistical discrepancy. 
Table 11. Romania: Schedule of Purchases Under the Stand-By Arrangement

\begin{tabular}{|c|c|c|c|}
\hline Date & $\begin{array}{l}\text { Amounts } \\
\text { in millions } \\
\text { of SDRs }\end{array}$ & $\begin{array}{l}\text { In percent } \\
\text { of quotal }\end{array}$ & Conditions \\
\hline November 2001 & 52 & 5.05 & Board approval of Stand-By Arrangement \\
\hline August 2002 & 82.666 & 8.02 & $\begin{array}{l}\text { Observance of end-March quantitative } \\
\text { performance criteria, structural } \\
\text { performance criteria and completion of } \\
\text { first and second reviews }\end{array}$ \\
\hline November 2002 & 55.111 & 5.35 & $\begin{array}{l}\text { Observance of end-September } \\
\text { performance criteria and completion of } \\
\text { quarterly review }\end{array}$ \\
\hline February 2003 & 55.111 & 5.35 & $\begin{array}{l}\text { Observance of end-December } \\
\text { performance criteria and completion } \\
\text { of quarterly review }\end{array}$ \\
\hline April 2003 & 55.112 & 5.35 & $\begin{array}{l}\text { Observance of end-March performance } \\
\text { criteria and completion of quarterly } \\
\text { review }\end{array}$ \\
\hline Total Remaining & 248 & 24.07 & \\
\hline $\begin{array}{l}\text { Total Under } \\
\text { Arrangement }\end{array}$ & 300 & 29.12 & \\
\hline
\end{tabular}

${ }^{1}$ The quota is SDR $1,030.2$ million. 


\section{ROMANIA-RELATIONS WITH THE FUND \\ (As of June 30, 2002)}

I. Membership Status: Joined 12/15/72; Article VIII

II. General Resources Account:

Quota

Fund holdings of currency

SDR million

\% Quota

$1,030.20$

100.00

$1,292.33$

125.44

III. SDR Department:

Net cumulative allocation

SDR million

75.95

\% Allocation

Holdings

0.51

100.00

0.67

IV. Outstanding Purchases and Loans:

Stand-By Arrangements

SDR million

$\%$ Quota

199.29

19.34

Systemic Transformation

62.84

6.10

V. Financial Arrangements:

Type

\begin{tabular}{|c|c|c|c|}
\hline & $\begin{array}{l}\text { Expira- } \\
\text { tion }\end{array}$ & $\begin{array}{l}\text { Amount } \\
\text { Approved }\end{array}$ & $\begin{array}{l}\text { Amount } \\
\text { Drawn }\end{array}$ \\
\hline & Date & (SDR million) & (SDR million) \\
\hline
\end{tabular}

Stand-By

$10 / 31 / 01 \quad 04 / 29 / 03$

300.00

52.00

Stand-By

$08 / 05 / 99$

$02 / 28 / 01$

400.00

139.75

Stand-By

$04 / 22 / 97 \quad 05 / 21 / 98$

301.50

120.60

$05 / 11 / 94 \quad 04 / 22 / 97$

320.50

94.27

Stand-By

$05 / 29 / 92 \quad 03 / 28 / 93$

314.04

261.70

Stand-By

$04 / 11 / 91 \quad 04 / 10 / 92$

380.50

318.10

VI. Projected obligations to Fund (SDR million; based on existing use of resources and present holdings of SDRs):

Overdue

$\underline{07 / 31 / 01}$

Principal

Charges/interest

Total
Forthcoming

$\underline{2001} \quad \underline{2002} \quad \underline{2003} \quad \underline{2004} \quad \underline{2005}$

$\begin{array}{lllll}38.3 & 29.9 & 79.6 & 79.0 & 47.7\end{array}$

$\begin{array}{lrrrr}\frac{7.8}{46.1} & 3.0 \\ 34.9 & \frac{8.4}{88.0} & \frac{5.6}{84.6} & \frac{3.4}{51.1}\end{array}$

VII. Exchange Rate Arrangements

From August 1994, a decentralized direct dealing interbank market has been in operation. The official reference rate published by the NBR is an average of rates reported for interbank and client transactions. Romania has accepted the obligations of Article VIII, Sections 2, 3, and 4, with effect from March 25, 1998. Its exchange system is largely free from exchange 
restrictions and multiple currency practices, with the exception of some bilateral payment arrangements and clearing agreements used to settle balances inherited from CMEA. Romania maintains de jure a managed floating exchange rate regime with no preannounced exchange rate path, while the de facto regime is a crawling band with unspecified width.

VIII. Article IV Consultation

Romania is on a 12-month consultation cycle. The last consultation was concluded on November 29, 2000.

\section{Technical Assistance}

The transition in Romania has been supported by substantial technical assistance from multilateral agencies and bilateral donors. The Fund has provided support in a number of areas with more than 40 technical assistance missions since 1990, although the authorities have had a mixed record with regard to implementation. Expert Fund assistance has focused on a number of key areas, including: fiscal reforms; modernization of the central bank and the banking system; creating a market-oriented legal structure; training; and improving the collection and reporting of statistics. In January 2002 and July 2002 a technical assistance mission of the Fund's Fiscal Affairs Department on tax administration issues visited Bucharest. In May 2002, a fiscal ROSC mission of the Fund's Fiscal Affairs Department visited Bucharest.

\section{Safeguards Assessment}

Under the Fund's safeguards assessment policy, the National Bank of Romania (NBR) is subject to a full safeguards assessment with respect to the Stand-By-Arrangement, which was approved on October 31, 2001 and is scheduled to expire on April 29, 2003. A full safeguards assessment was completed on May 13, 2002. The assessment concluded that considerable progress has been made by the authorities in strengthening the external audit mechanism and the financial reporting framework. However, certain weaknesses were identified, most notably in the internal controls system, and the safeguards assessment recommended remedial actions to address the identified vulnerabilities.

XI. Resident Representative

The Fund has had a resident representative in Bucharest since 1991. Mr. Stephane Cosse assumed the post in December 1999. 


\section{ROMANIA: RELATIONS WTTH THE WORLD BANK}

1. The World Bank has been active in Romania since 1991 and has built up a portfolio of 33 Bank-financed operations with total commitments of US\$3.3 billion. Romania's portfolio is the second largest in ECA in terms of number of projects and the fourth largest in terms of commitments. The active portfolio as of July 30,2002 consists of 19 projects with aggregate net commitments totaling $\$ 1,043$ million and a total undisbursed balance of US $\$ 447.6$ million. Sector composition in terms of commitments is dominated by energy and infrastructure ( 53 percent, six projects) and the social sectors ( 26 percent, nine projects).

2. The quality of the Bank's Romania portfolio has been improving over the past several years. While the overall performance indicators are positive, several cross-cutting implementation issues persist. These include: (i) the need for special attention to monitoring and evaluation capacity building; (ii) the need to align financial reporting requirements with international best practice; and (iii) the need to strengthen the Government's budget prioritysetting process, to ensure adequate IBRD loan disbursements and counterpart funding, in order to yield maximum development impact from the Bank's portfolio.

3. A new Country Assistance Strategy (CAS), covering the three-year period of FY02FY04, was presented to the World Bank's Board on June 19, 2001. The CAS defines the Bank's lending and advisory services based on the Government's priorities of poverty reduction and EU accession, and builds on the work initiated under the Comprehensive Development Framework, for which Romania is one of the pilot countries. About one half of the FY02-04 lending program is adjustment lending. A follow-up operation to PSAL (PSAL II) has been negotiated and will be presented to the World Bank Board once the Government has taken actions that will be necessary to allow it to meet second tranche conditions. It would support reforms encouraging private sector development-including reform of the enterprise, energy, and financial sectors. Subsequent adjustment operations would support reforms of the Government's institutional, regulatory, and governance framework, as well as continued reforms for private sector development.

4. The World Bank has maintained a highly collaborative relationship with its counterparts at the IMF. PSAL I, approved in June 1999 and completed one year later, complemented the IMF's Stand By Arrangement and was developed in close consultation with the IMF's Romania team and management. Similar consultations have taken place in the development and design of PSAL II.

5. As of June 2002, IFC has approved 18 projects with US $\$ 220$ million for IFC's own account and US $\$ 240$ million in syndicated loans. Looking forward, the level of IFC activity will depend on the extent of improvements in the enabling environment for business in the country. IFC will attempt to complement the Bank's efforts in private sector development by focusing on four key areas: restructuring of municipal infrastructure, financing for postprivatization restructuring; supporting financial markets development and SME growth, and selected private sector investments. IFC will continue to catalyze the entry of FDI into the key industrial and financial sectors. 


\section{ROMANIA: STATISTICAL IsSUES}

1. Romania's data collection and reporting is adequate for surveillance and program monitoring. The authorities have made some progress in improving their statistical base over the past three years with the help of Fund TA missions, although more needs to be done, in particular in the area of balance of payments, and the consistency between monetary and fiscal data. Romania has participated in the GDDS since February 2001. A STA mission visited Romania in November 2000 to assist the authorities in preparing metadata. The mission also prepared a data module for the $\mathrm{ROSC}$, which is posted on the IMF website.

\section{Real Sector}

2. The national accounts statistics produced by the National Institute for Statistics (INS) for quarterly and annual series on Gross Domestic Product are methodologically sound, but arrive with lag of about 3 months. Furthermore, harmonization of quarterly and annual national accounts is not done on a regular basis and late revisions can sometimes be significant; the 1999 GDP growth rate, previously reported as -3.2 percent, was revised to -2.3 percent in April 2001. The INS has moved to update the framework from the European System of Accounts 1979 (ESA79) to ESA95, and data based on ESA95 were released at the end of 2000. The INS staff has been downsized significantly over the past two years, which might affect the quality and timeliness of the data.

3. The Consumer Price Index (CPI) is subject to the standard anmual re-weighting, and it is considered to be a reliable source. However, the INS reduced the coverage of the Producer Price Index (PPI) from the value of all shipments of the covered industries to shipments for domestic uses only, beginning with 1998 data. The INS planned to reinstate export coverage with the next index revision sometime in 2001.

\section{Public Finance}

4. Consolidated data on central government operations are occasionally reported for the GFS Yearbook (transaction data, but not debt data, only through 1999 are in the GFS Yearbook 2001) and often reported for IFS, while the EU1 department receives monthly budget data. A multi-sector statistics mission visited Romania in December 1999 and recommended that all major fiscal categories be reported on a quarterly and monthly basis. The mission also called for the documentation and reporting of all government transactions related to the Agency for Bank Asset Recovery (AVAB), which has been receiving large amounts of nonperforming bank claims in exchange for the bank receipts of government securities. The multi-sector mission also recommended the introduction of detailed financing and debt classifications in the Treasury's chart of accounts and budget classifications. Work continues on the establishment of a new aid coordination unit to monitor data on grants.

\section{Monetary and Financial}

5. The National Bank of Romania (NBR) reports money and banking statistics for IFS on a regular and timely basis. The NBR adopted accrual accounting as part of the introduction of a new chart of accounts. However, loans extended by the NBR and the 
commercial banks continue to be recorded on a cash basis. Also, in contrast to the Monetary and Financial Statistics Manual and the fifth edition of Balance of Payments Manual residency recommendations, NBR's foreign assets exclude Romania's membership subscriptions in international organizations, such as Romania's IMF quota and subscriptions to the World Bank, European Bank for Reconstruction and Development, Bank for International Settlements, International Financial Corporation, and the Multilateral Investment Guarantee Agency, which are classified as domestic assets. Similarly, deposits of these organizations, including the IMF deposits that correspond to the IMF quota, are classified as domestic liabilities.

6. The multi-sector mission in December 1999 stressed that the institutional coverage of the NBR's monetary statistics is incomplete. The Article IV mission encouraged the authorities to include deposit-taking institutions, which operate under the cooperative law, in the coverage of the monetary statistics.

\section{Balance of Payments}

7. The National Bank of Romania routinely reports balance of payments statistics in a timely fashion. Data collection and compilation have improved following technical assistance. The ROSC data module of November 2001 noted that the authorities were in the process of implementing a program of improvements to the data collection and compilation systems for the balance of payments and international investment position data. It noted particular concerns with (1) the coverage of the direct investment data (stocks and flows) and related income flows and (2) the quality of data on current transfers, in particular with the general government sector. Improvements planned included the introduction of a survey of direct investment in Romania to address (1) above; improvements to the monitoring of aid flows into Romania to address (2); and an improved international transactions reporting system that would provide more detailed information to allow for improved classification of transactions between residents and nonresidents of Romania. 
Table 1: Romania: Core Statistical Indicators as of August 6, 2002

\begin{tabular}{|c|c|c|c|c|c|c|c|c|c|c|c|c|}
\hline & $\begin{array}{c}\text { Exchange } \\
\text { Rates }\end{array}$ & $\begin{array}{l}\text { Interna- } \\
\text { tional } \\
\text { Reserves }\end{array}$ & $\begin{array}{l}\text { Central } \\
\text { Bank } \\
\text { Balance } \\
\text { Sheet }\end{array}$ & $\begin{array}{c}\text { Reserve/ } \\
\text { Base } \\
\text { money }\end{array}$ & $\begin{array}{l}\text { Broad } \\
\text { Money }\end{array}$ & $\begin{array}{l}\text { Interest } \\
\text { Rates }\end{array}$ & $\begin{array}{c}\text { Consumer } \\
\text { Price } \\
\text { Index }\end{array}$ & $\begin{array}{l}\text { Exports } \\
\text { Imports }\end{array}$ & $\begin{array}{l}\text { Current } \\
\text { Account } \\
\text { Balance }\end{array}$ & \begin{tabular}{|c|} 
Overall \\
Govern- \\
ment \\
Balance
\end{tabular} & $\begin{array}{l}\text { GDP/ } \\
\text { GNP }\end{array}$ & $\begin{array}{c}\text { External } \\
\text { Debt/ } \\
\text { Debt } \\
\text { Service }\end{array}$ \\
\hline $\begin{array}{l}\text { Date of Latest } \\
\text { Observation }\end{array}$ & $\begin{array}{l}\text { Aug. } 6 \\
2002\end{array}$ & $\begin{array}{l}\text { Aug. 2, } \\
2002\end{array}$ & $\begin{array}{l}\text { June } \\
2002\end{array}$ & $\begin{array}{l}\text { Aug. 2, } \\
2002\end{array}$ & $\begin{array}{l}\text { June } \\
2002\end{array}$ & $\begin{array}{l}\text { June } \\
2002\end{array}$ & $\begin{array}{l}\text { June } \\
2002\end{array}$ & $\begin{array}{l}\text { June } \\
2002\end{array}$ & $\begin{array}{l}\text { May } \\
2002\end{array}$ & $\begin{array}{l}\text { June } \\
2002\end{array}$ & $\begin{array}{c}Q 1 \\
2002\end{array}$ & $\begin{array}{l}\text { June } \\
2002\end{array}$ \\
\hline Date Received & $\begin{array}{c}\text { Aug. } 6 \\
2002\end{array}$ & $\begin{array}{c}\text { Aug. 2, } \\
2002\end{array}$ & $\begin{array}{c}\text { July } 30 \\
2002\end{array}$ & $\begin{array}{l}\text { Aug. } 6, \\
2002\end{array}$ & $\begin{array}{c}\text { July } 30 \\
2002\end{array}$ & $\begin{array}{c}\text { Aug. 2, } \\
2002\end{array}$ & $\begin{array}{l}\text { July } \\
2002\end{array}$ & $\begin{array}{l}\text { July } \\
2002\end{array}$ & $\begin{array}{l}\text { July } \\
2002\end{array}$ & $\begin{array}{c}\text { July } 25 \\
2002\end{array}$ & $\begin{array}{c}\text { July } 18, \\
2002\end{array}$ & $\begin{array}{c}\text { July } 25, \\
2002\end{array}$ \\
\hline $\begin{array}{l}\text { Frequency } \\
\text { of Data }\end{array}$ & $\mathrm{D}$ & $\mathrm{D}$ & $\mathrm{M}$ & $\mathrm{D}$ & $\mathrm{M}$ & $\mathrm{D}$ & $\mathrm{M}$ & $\mathrm{M}$ & $M$ & $\mathbf{M}$ & $Q$ & $\mathrm{M}$ \\
\hline $\begin{array}{l}\text { Frequency of } \\
\text { Reporting }\end{array}$ & $\mathrm{D}$ & $\mathrm{D}$ & $\mathbf{M}$ & $\mathrm{BW}$ & $\overline{\mathrm{M}}$ & $\mathrm{D}$ & $\mathbf{M}$ & $\mathrm{M}$ & $\mathrm{M}$ & $\overline{\mathrm{M}}$ & $Q$ & $\mathbf{M}$ \\
\hline $\begin{array}{l}\text { Source of } \\
\text { Update }\end{array}$ & A & $\mathrm{A}$ & A & $\mathrm{A}$ & A & $\mathrm{A}$ & $\mathrm{N}$ & $\mathrm{A}$ & $A$ & $A$ & $\mathrm{C}$ & $\bar{A}$ \\
\hline $\begin{array}{l}\text { Mode of } \\
\text { Reporting }\end{array}$ & $\mathrm{C}$ & $\mathrm{E}$ & $\mathrm{E}$ & $\mathrm{E}$ & $\mathrm{E}$ & $\mathrm{C}$ & $\mathrm{C}$ & $\mathrm{E}$ & $E$ & $\mathrm{E}$ & $\mathrm{C}$ & $\mathrm{E}$ \\
\hline Confidentiality & $\mathrm{C}$ & $\mathrm{A}$ & A & A & $\mathrm{A}$ & $\mathrm{C}$ & $\mathrm{C}$ & $\mathrm{A}$ & $\mathrm{C}$ & $A$ & $\mathrm{C}$ & A \\
\hline $\begin{array}{l}\text { Frequency of } \\
\text { Publication }\end{array}$ & $\mathrm{D}$ & $\overline{\mathbf{M}}$ & $\mathbf{M}$ & $\overline{\mathrm{M}}$ & $\mathrm{M}$ & D & $\mathbf{M}$ & $\mathrm{M}$ & $\mathbf{Q}$ & $\mathbf{M}$ & $Q$ & $Q$ \\
\hline
\end{tabular}

(CInternational Monetary Fund. Not for Redistribution 
Mr. Horst Köhler

August 12, 2002

Managing Director

International Monetary Fund

Washington, D.C. 20431

Dear Mr. Köhler:

Since the approval of the Stand-By Arrangement by the IMF Board on October 31, 2001, macroeconomic developments have been in line with the program. After strong GDP growth of 5.3 percent in 2001, we expect only a moderately weaker performance in 2002, owing to a lower contribution of agriculture. We brought inflation down to 31 percent at end2001 , and to 24 percent in June 2002, fully in line with our 22 percent target for end-2002. The current account deficit was contained below 6 percent in 2001, and we expect it to decline to 5 percent of GDP in 2002 . The increase in foreign reserves was significantly stronger than envisaged under the program. Over the last 12 months, two major rating agencies have twice upgraded Romania's sovereign risk.

The attached Supplementary Memorandum on Economic and Financial Policies (SMEFP) specifies understandings reached with the staff in the context of discussions on the completion of the first and second reviews. In particular, the SMEFP specifies the corrective actions needed to address the nonobservance of three quantitative and three structural performance criteria, for which we request waivers. To ensure optimal conditions for the privatization of $\mathrm{BCR}$, the largest state-owned bank, we are also requesting the modification of the structural performance criterion on its completion by postponing the date from endDecember 2002 to end-February 2003.

On the strength of the corrective measures specified in the SMEFP, most of which have already been implemented, we are requesting the completion of the first and second reviews under the arrangement. We are also requesting that the arrangement be rephased, and the fourth purchase be proportionally redistributed across the remaining purchases under the arrangement.

We remain determined to meet all our commitments under the program. We believe that the policies and measures described in the attached memorandum are sufficient to achieve the objectives of the program, but we stand ready to take additional measures and seek new understandings with the IMF if necessary to keep the program on track. The Government of Romania will remain in close consultation with the IMF in accordance with the IMF's policies on such consultations, and it will provide the IMF with all the information that it requests to assess the implementation of the program.

Yours sincerely,

$/ \mathrm{s} /$

Mihai Tanasescu

Minister of Public Finance

Ministry of Public Finance
$/ \mathrm{s} /$

Mugur Isarescu

Governor

National Bank of Romania 


\section{Supplementary Memorandum on Economic and Financial Policies}

\section{INTRODUCTION}

1. Since the approval of the Stand-By Arrangement by the IMF Board on October 31, 2001, we have made significant progress toward realizing the main macroeconomic objectives of our program. However, a number of hurdles have arisen in the quasi-fiscal and structural areas, which we have addressed through additional measures. This memorandum, prepared in the context of the first and second reviews under the arrangement, supplements the original Memorandum on Economic and Financial Policies (MEFP) and specifies these additional measures, which aim at sustaining progress on macroeconomic stabilization and accelerating structural reforms.

\section{BACKGRound AND REQUEST FOR WaIVERS}

2. Macroeconomic developments since October 2001 have been broadly in line with the program. GDP grew by 5.3 percent in 2001 on account of a strong recovery in agriculture. Industrial production, however, slowed in the second half of 2001, owing in part to weaker import demand of our trading partners. As this carried over to early 2002, GDP growth declined to 3.1 percent in the first quarter, but we expect that it will soon accelerate, in line with the strengthening in economic activity in Europe. The 12-months headline inflation rate fell to 24 percent in June, in spite of the continuing adjustment in administered prices. The current account deficit was close to the program target of 6 percent of GDP in 2001 , and it declined further in early 2002 . With returning confidence, foreign reserves strengthened more than programmed, and have now reached a comfortable level of 3.8 months of imports of goods and services.

3. Monetary and budget policies have been on track. The end-December and endMarch performance criteria and the end-June indicative targets on monetary policy (NDA and NFA of the NBR) were met with comfortable margins (see Table 1). The deficit targets for the general government in 2001, and Q1 and Q2 of 2002 were also met, despite an unanticipated revenue shortfall.

4. We implemented all adjustments in energy prices envisaged under the program, except for a small modification. A somewhat lower effective increase in electricity prices in March 2002, owing to two socially motivated measures (reduction in fixed charges for households and an increase in quantities delivered at social tariffs), was corrected by adjustments in other electricity prices. We therefore request a waiver for the nonobservance of the corresponding March 2002 structural PC.

5. Progress in improving the collection rates of the main utilities was uneven. In Q4 of 2001 and $\mathrm{Q} 1$ of 2002, the collection rates of the two gas distribution companies and Termoelectrica's rate for heating deteriorated, while improvement in collections for electricity was much lower than targeted under the program. As a result, the corresponding end-March quantitative PCs on the collection rates were missed by a substantial margin. We 
request waivers for the nonobservance of these $\mathrm{PCs}$ on the basis of the corrective actions described in $\$ 22$ and $\$ 23$ below, and somewhat improved performance in Q2 of 2002.

6. To strengthen our wage policy, we approved most of the state-owned companies' 2002 budgets already in December 2001. Only a few budgets were not approved until January 2002. As this has not put at risk the implementation of our wage policy in 2002, we request a waiver for the nonobservance of the corresponding structural PC.

7. However, we have had some difficulties in meeting our wage policy targets. As a result of higher-than-expected wage payments in Q3 of 2001, the end-December target for wage bills in state-owned enterprises was exceeded by 2.3 percent, despite our efforts to contain wage growth in the last quarter by reducing or postponing bonuses. The carry-over effect and the delayed payment of December bonuses also resulted in the nonobservance of the end-March 2002 quantitative $\mathrm{PC}$, for which we request a waiver, based on corrective measures described in $\uparrow 17$ and 118 .

8. We completed the privatization of the largest steel company Sidex, but our progress has been somewhat slower with other privatization projects. We privatized five large companies in January-June, compared with eight set as a benchmark, but we are strongly determined to accelerate privatization in the months ahead. Corrective actions for this purpose are described below in $925-29$. We issued a preliminary announcement of the privatization of the largest state-owned bank, BCR, on March 1, given some delays in hiring a privatization advisor, our full-fledged invitation for the expression of interest was not issued until June 24 , resulting in the nonobservance of the end-February structural PC, for which we request a waiver.

\section{Policy Measures Implemented in the Context OF The First and Second REVIEWS}

9. We are committed to achieving our main macroeconomic objectives for $\mathbf{2 0 0 2}$ and 2003: (i) reduce inflation to 22 percent by end-2002 and to 15 percent by end-2003; (ii) contain the current account deficit close to 5 percent of GDP in 2002 and reduce it further in the following year, and (iii) raise official reserves to 4 months of imports by end-2003. We expect that GDP growth will be about 4-41/2 percent in 2002 (compared with the original program projection of 5 percent), and that it will return closer to our capacity growth rate of about 5 percent in 2003 . We are aware that this performance is possible, but that we must continue with the program of structural reforms and improve the business climate. Our policies, described below, are designed to achieve these objectives. Moreover, we are requesting that the review based on end-June 2002 data be eliminated and the arrangement be rephased, with the fourth purchase being proportionally redistributed across the remaining purchases under the arrangement. Quarterly performance criteria under the program for endSeptember and end-December 2002 are presented in Table 1. 


\section{A. Fiscal Policy}

10. Due to the weaker-than-expected revenue performance since the approval of the 2002 budget and a downward revision of GDP growth, we have implemented additional measures to achieve our 2002 budget deficit target of lei 43.2 trillion:

- The 40 percent excise reduction for producers of cigarettes using domestic tobacco under Emergency Ordinance 186/2001 was eliminated in March 2002 (prior action).

- Effective May 1, 2002, we increased excise taxes on gasoline, ethyl alcohol and distilled alcoholic beverages, as well as the specific tax on beer (prior action). Moreover, we increased royalties in the mining sector and introduced royalties on the use of oil and gas pipelines in April 2002.

- To broaden the tax base of the pension and the unemployment fund, we submitted to Parliament in June, and will start to enforce on October 1, 2002, new legislation providing for the conversion of work contracts currently not subject to social security contributions into regular part-time employment. Moreover, we are working to strengthen the capacity of the labor inspectorate and the exchange of information between the social security funds and the tax administration to crosscheck income declarations.

11. In line with the original MEFP, we have implemented the following measures to reform our tax system:

- The new VAT law (prior action), which became effective on June 1, eliminated VAT exemptions and zero rating for the construction of dwellings, railroad infrastructure, and tourism. Exemptions for imports by small and medium-size enterprises (SMEs) have also been eliminated and, henceforth, all customs duty exemptions will be exclusively regulated through the customs duty tariff and will be uniform for all economic agents. Furthermore, the VAT threshold has been raised to the lei equivalent of $€ 50,000$, and the turnover ceiling for microenterprises will be aligned with this threshold on January 1 , 2003.

- The new profit tax law (prior action), which entered into force on July 1, eliminated distortionary tax incentives, profit tax holidays and exemptions under several laws, and replaced them with a uniform 20 percent investment tax allowance. The reduced 6 percent profit tax rate for exporting activities will be raised to 12.5 percent as of January 1,2003 , and to the standard rate as of January 1,2004. To limit the revenue loss during the transition period, companies can benefit either from the reduced rate or the investment tax allowance. Grandfathering applies only to time-bound incentives.

- We will not introduce tax holidays or any other new distortionary tax incentives or postpone the discontinuation of expining ones (continuous structural benchmark). 
12. In spite of all these measures, a significant risk remains that revenues could fall short of the budget target by 5 trillion lei ( 0.3 percent of GDP). On the expenditure side, we expect savings of lei 6.3 trillion on interest payments, lower cofinancing for EU grants (lei 1 trillion), and lower nonpension-related expenditures of the pension fund (lei 1 trillion). In addition, through the ordinance on the budget rectification, we will block lei 2 trillion of the expenditure entitlements of the road fund. This amount can only be released if the cumulative end-September revenue target agreed with Fund staff has been met (see TMU; Section III). Moreover, a decision on a potential further budget rectification in the fourth quarter of 2002 will be made only after consultation with Fund staff. Based on these savings, we will under the first budget rectification increase spending in other expenditure categories (costs of military operations in Afghanistan, transfers to local governments, and others) by at most lei 4.5 trillion.

\section{While we have not yet finalized the preparations for the $\mathbf{2 0 0 3}$ budget, we have} already decided the following:

- We are firmly committed to reduce the deficit of the general consolidated budget to 2.65 percent of GDP in 2003, with a view to continuing our successful disinflation efforts and containing the current account deficit. The target reflects our firm resolve to keep the deficit below its sustainable medium-term level in years with strong GDP growth. This moderate fiscal consolidation will also help lessen the impact of the minimum wage increase in 2003 and its effects on household demand.

- Following the reduction of the extraordinarily high payroll taxes by 3 percentage points in 2002 , we have decided to reduce these taxes by an additional 5 percentage points in 2003. On January 1, 2003, we will eliminate the remaining 2 percent payroll tax for the previous special fund for handicapped persons and reduce social security contributions by 3 percentage points, with the employcrs' and the employees' rates being cut by 0.33 and 2.67 percentage points, respectively. We are convinced that this measure will help to broaden the tax base and reduce the scope of the "gray" labor market.

- To ensure the availability of budgetary resources for improving our social safety net, and because the reduction in payroll taxes implics a substantial revenue loss, we have decided to refrain from any other tax cuts in 2003. In particular, we will not introduce a reduced VAT rate or reduce the income tax rate.

- We have decided to limit the annual average increase in the 2003 net wage bill of the general consolidated budget to 3 percent in real terms, which will also contribute to moderating wage demands in state-owned enterprises.

- To improve the transparency of our fiscal policy, we have decided that, starting with the 2003 budget, the special fund for roads and the special fund for the development of energy systems will be incorporated into the state budget. Moreover, the tax on electricity used to finance the latter will be reduced by 1 percentage point on January 1, 2003, in order to reduce the production costs in the industrial sector. 
I4. We will approve a social program for $2002-03$ to soften the impact of the increase in utility prices on low-income households and further improve our social safety net:

- In particular, on November 1, 2002, heating-related transfers to eligible households will be increased by 40 percent for centralized heating, by 25 percent for natural gas, and by 20 percent for wood and coal compared with the amounts effective in the first quarter of 2002. Moreover, the income ceilings for the eligibility for heating-related transfers will be increased by 17 percent in nominal terms on November 1, 2002. The new transfer amounts and income ceilings will not be further adjusted before November 1, 2003.

- The income ceilings for the minimum income guarantee scheme will be increased by 17 percent in nominal terms on January 1, 2003, and will remain unchanged during 2003. Child allowances will be increased by 17 percent in nominal terms on January 1, 2003 . Starting on January 1, 2003, we will reduce the scope for deducting child exemptions from the taxable income for high-income households (details of this reform will be discussed with Fund staff in the context of the third review). We will not further adjust child allowances before January 1, 2004. We will explore the feasibility of gradually phasing in the program to distribute free milk and bakery products to pupils in elementary schools, with priority being given to pupils in the first four grades and those in disadvantaged areas.

- We will leave the decision on the introduction of equal monthly payments for households using centralized heating to each individual district heating company. The government will not issue guarantees for loans contracted by local heating producers or distributors for this purpose.

- We will postpone the approval of other measures included in the draft social program for 2002-03 which require additional budgetary resources until after we have prepared the 2003 budget in consultation with Fund staff. In addition, we will review, in consultation with Fund staff, the affordability of maintaining the link between the level of unemployment benefits and the economy-wide minimum wage in the context of the preparations of the 2003 budget.

- The impact of the above-referenced measures on the 2002 budget will be moderate (lei 758 billion) as the time lags for billings and payments for centralized heating and natural gas imply a postponement of the budgetary impact to 2003 . The additional amount will be financed from savings in nonpension related expenditures of the pension fund.

15. We will continue reforming tax administration based on the recommendations of the Technical Assistance mission of the IMF's Fiscal Affairs Department. Specifically, we will (a) immediately subordinate all tax administration functions under one Secretary of State in the Ministry of Finance; (b) establish a large taxpayer directorate in Bucharest by January 1, 2003, at the latest; and (c) create a unified and separate tax administration 
department reporting directly to the Minister of Finance by end-June 2003, at the latest. Furthermore, we will integrate the three existing administrations for the collection, audit and enforcement of social security contributions into a single new administration under the Ministry of Public Finance on January 1, 2004, at the latest. To achieve this objective, we will appoint the project manager by mid-September 2002, the full project implementation team by end-September 2002 and will approve the new legislation by end-September 2002 .

\section{We have requested an increase in the ceiling on off-budget guarantees by} US\$200 million in 2002, to facilitate investment in the broadcasting system and the second phase of the nuclear power plant Cernavoda. We consider the completion of the second phase, which is already in an advanced stage, as crucial for our strategy to modemize Romania's energy sector and estimate that total borrowing for this purpose over a period of five years would amount to US\$750 million, which would not adversely affect our external position. As both projects will generate resources for the repayment of loans, the guarantee will not impose a burden on the budget.

\section{B. Wage Policy}

\section{We remain committed to keep wage costs in state-owned enterprises below the} program ceilings. The Program to Contain Wages and Reduce Employment (October 2001) for about 80 monitored companies, and a subsequent government decision on quarterly ceilings (prior action) limited the growth in aggregate wage bills to 22 percent in 2002, and envisaged a total net reduction in employment of 20,340 positions (excluding all forms of outsourcing). The total employment reduction will include at least 14,500 layoffs, out of which more than 8,000 have already been implemented. The latter include 4,200 layoffs in companies under the Ministry of Industry (prior action), to compensate for the shortfall in employment reduction in the fourth quarter of 2001.

18. We also adopted further safeguards. At most 65 percent of the total bonuses will be paid during the first three quarters. Furthermore, 4 percent of the quarterly wage bill can be paid only with the permission of the respective minister. As the wages in state-owned enterprises continue to outpace economy-wide wages, and the end-June target for the wage bill was likely missed, we have activated this buffer for the Q3 wage bill through Ministerial Orders of the Minister of Industry, the Minister of Transportation, the Minister for Privatization, and the Minister for Communication instructing managers to reduce or eliminate bonuses (prior action).

19. We will prevent a translation of the minimum wage increase, which we consider as important to help lessen the impact of the energy price adjustments on low-income households, into a rise of the overall wage level in state-owned enterprises. We believe that the secondary effects of the minimum wage hike on the overall wage level are limited, as most collective contracts at the enterprise level no longer include an automatic adjustment in the wage scale due to increases in the statutory minimum wage. Nevertheless, to ensure that the minimum wage increase will not affect the overall wage level in the public sector, we will instruct managers of all state-owned companies to raise wages only for those employees 
whose wage earnings (base wage plus all mark-ups) are below the minimum wage level on January 1,2003. We will strictly require that wage payments in these companies observe the established quarterly ceilings, and we will reduce the salaries of the managers who do not observe them. Moreover, the new minimum wage will not be increased again during 2003, and not be indexed either to the CPI or foreign currencies.

20. In 2003, we will implement the same wage-control mechanism for public enterprises as in 2002. Specifically, we will approve by mid-November 2002, after consultation with Fund staff, a government decision establishing quarterly ceilings for wage bills and employment of the monitored companies. On this basis, we will approve in December 2002 the annual budgets of these companies for 2003, ensuring that growth in their aggregate gross wage bill is limited to 14 percent compared with 2002 (a structural performance criterion), adjusted for any kind of outsourcing. To achieve this target, and to accelerate restructuring, we will continue reducing employment in these companies. In addition to layoffs, the government will impose a hiring freeze in at least 90 percent of the monitored state-owned companies (as measured by employment), which will limit hiring to no more than 30 percent of the vacancies in each company. Companies will only be excluded from the set of monitored state-owned companies, with the corresponding adjustment of the aggregate wage bill ceiling, (a) after their privatization has been finalized; or (b) when they have not registered losses or arrears for three consecutive years.

\section{Energy Sector Reforms}

\section{As envisaged in our program, we have continued with the adjustment of} administered prices. As of April 10, 2002, all end-user electricity prices were raised by 14 percent, and Termoelectrica's producer price was raised to US\$39 per MWh, a level that would assure full cost recovery. (A somewhat lower than originally targeted adjustment in the latter reflected a revised estimate of production costs realized in 2001.) As of July 1, 2002, Termoelectrica's heating producer price has been raised to US\$20 per Gcal and on July 9,2002 we issued a government decision to raise the National Reference Heating price to lei 800,000 per Gcal as of August 1, 2002, which implies a price of US\$20 per Gcal net of VAT. We will also adjust electricity and gas prices every quarter to keep them constant in U.S. dollar terms (see Table 3).

22. We will continue to implement the policies for enforcing payments to utilities and discontinuing supplies to industrial energy users with a weak payment record. As of April 20, we have started to disconnect the 20 largest nonpayers to each of the three utilities (DGN, DGS, and Electrica) that had not paid their outstanding bills (prior action; see TMU, Section VI). The remainder of their arrears on January 31, 2002 has been denominated in euro and rescheduled over a maximum period of 24 months. We will now extend this measure to all other companies-whether public, in the process of privatization or private.

23. We have implemented the following measures to improve the collection performance in the local district heating sector: 
- Protocols on the transfers of 16 of Termoelectrica's heat-producing units to local municipalities were signed by June 2002 . We expect that the municipalities will seek to improve the collection performance and find more efficient sources of heating supplies. We will, therefore, limit the issuance of state guarantees to the 16 units only to fuel supplies for the next heating season to an amount that will not exceed US\$120 million.

- As of May, 2002, the two gas distribution companies have discontinued supplies to municipal heating companies with the weakest payment records (see TMU; Section VI). We will keep this policy unchanged during the program period.

- While Termoelectrica did not disconnect the weakest-paying municipal heating companies in an even manner, we will now instruct its management to enforce this measure strictly. State guarantees to Termoelectrica for fuel supplies during the heating period 2002-03 will not exceed US\$200 million.

- We will reinforce our efforts to complete the installation of metering systems.

- We will continue to rely on the system of escrow accounts, under the control of the Ministry of Public Finance, to ensure that all cash collections by municipal heating companies are deposited daily into the accounts. In addition, all the subsidies from the state budget and local authorities to district heating companies during the next winter season will be paid fully and on time into these accounts.

- To improve collections from households to the utilities, we will modify Law 326/2001 by mid-September 2002 in order to reduce the deadline for payments to 15 days, and for disconnections to 45 days. ${ }^{1}$

24. After some delays, we are now proceeding with the privatization of the two gas and two electricity distribution companies. We will sign the contract with the privatization advisors for the two gas companies by end-December 2002, approve the privatization strategy by end-March 2003, and announce the privatization tender by end-May 2003. After a delay, we also will announce the privatization tenders for two electricity distribution companies by mid-September 2002 . We will instruct the privatization advisor to search for the optimal privatization strategy, with preference being given to selling a majority share of these companies to strategic investors.

\section{Privatization}

\section{Privatization is crucially important to keep our economy on a rapid growth} path. To address the problem of over-indebtedness of state-owned enterprises scheduled for

\footnotetext{
${ }^{1}$ The revised targets for improving the efficiency in collections are set out in Table 1 and the revised method of calculating the collection rates is specified in the TMU, Section VI.
} 
privatization, we have passed a law that will allow a partial or full write-off of outstanding arrears to the budget when the company has in fact been effectively privatized. The law also provides for shorter procedural deadlines. As for the criteria for selecting winners in privatization tenders, the Ministry of Privatization notified the privatization advisors in April to increase the weight attached to the purchase price offered by the investor, to at least 50 percent. In addition, the tender documents will indicate that the targets for investment and employment are not mandatory. In amending Law 51/1998 (after consultations with World Bank and Fund staff), to provide an opportunity for potential buyers to present their business plans to trade unions before completing the sale, we will ensure that an agreement with the unions will not be a precondition for the sale.

\section{Following the privatization of five companies with more than 1,000 employees} between January 2002 and June 2002, out of which three were privatized as a prior action, we will privatize another eight such companies by end-September 2002 . We will also sign the contract with a privatization advisor for Petrom by mid-October 2002 and will approve the privatization strategy by end-December.

27. We have decided to proceed with the privatization of several large loss-making enterprises, which are also responsible for large arrears to energy suppliers. To facilitate their privatization, we have reduced employment by 950 positions in the four companies (Nitramonia, Tractorul, Roman, and Siderurgica), of which 750 have been reduced as a prior action.

- We offered Nitramonia for sale in March 2002; the tender failed and was relaunched in July. In the case of Tractorul, we relaunched the tenders for its units in June, after writing off debts to the governments in line with the new law, with bid submission deadlines in August. For Roman, we spun off seven subsidiaries in early July and will launch tenders for three of them by end-August, with the remaining four by end-September, and the parent company by end-December.

- For Siderurgica, we will offer four of the eight subsidiaries for sale by end-August and the other four subsidiaries by end-September; the parent company will be offered for sale by end-December.

- To increase the attractiveness of all these subsidiaries, if no bids are received after the first advertisement, we will immediately downsize employment before offering the company for sale again. If no bids are received within 180 days after the first advertisement, we will initiate liquidation procedures. As for the parent companies, if no bids are received within 180 days, we will wind up procedures through the sale of assets.

28. We will make every effort to proceed rapidly with the privatization of BCR. After signing the contract with the new privatization advisor in May (prior action) and issuing an invitation for the expression of interest in June, we will pre-select investors and launch the bidding process by September 15, and expect to obtain firm bids from strategic investors, as evidenced by "bid bonds," by October 31 (structural benchmark). Progress in 
the privatization of BCR will be subject to special attention in the context of the third review. We expect to complete the privatization of BCR (i.e., sign the contract with a strategic investor) by end-February 2003 , instead of by end-December 2002 . We request, therefore, a modification in this structural performance criterion.

29. We will continue our liquidation program for smaller unviable companies, to prevent accumulation of losses and release productive resources. In addition to the 21 companies already liquidated or privatized since October 2001, APAPS will commence liquidation procedures for 20 such companies with assets exceeding lei 10 billion by endSeptember, and for another 10 companies by end-December.

\section{E. Monetary Policy and Banking Issues}

30. Monetary policy will continue to be conducted in a managed float framework. Aided by the tight fiscal, quasi-fiscal, and wage policy stances, the NBR will gear its policies toward reaching the inflation objective, subject to preserving external viability by preventing unwarranted real appreciation. The current policy of less frequent interventions, allowing for wider exchange rate fluctuations, will continue, and the NBR will consider exchange rate movements of the leu against both the euro and the U.S. dollar. The interest rates on NBR's sterilization instruments are expected to continue declining gradually, in light of falling inflation, a strong demand for lei-denominated assets and the excess supply in the foreign exchange market.

\section{The rapid growth in foreign-currency-denominated credit poses risks for} maintaining financial soundness. As one measure to address these risks, on April 1, 2002, the NBR has unified its reserve requirements for lei and foreign currency deposits at 22 percent (from 25 percent and 20 percent, respectively), thus alleviating supply pressures to lend in foreign exchange. In addition, the NBR will exercise closer supervision of the most active lenders, in order to ensure their adequate assessment of credit risk. The tightening of loan provisioning (see below) should also help moderate credit growth. Finally, the NBR will extend the maturity of banks' liabilities in foreign currencies subject to the reserve requirement from one to two years by amending the respective regulation by August 1, 2002 .

\section{We are implementing the plans envisaged in the MEFP to strengthen the legal} and regulatory framework of the financial sector. Following intensive discussions with commercial banks on the draft regulation on loan provisioning, we have decided to rely to a greater extent on banks' internal norms for evaluation of borrowers' financial performance, provided the norms have been approved by the NBR. At the request of the Association of Commercial Banks, the value of real estate collateral, appropriately adjusted, will be deducted from the value of the loan before provisioning, but only if the loan is not more than 90 days overdue and no legal proceedings against the borrower have been injtiated. To obtain the support of all affected parties, the new regulation will be effective on January 1, 2003, six months later than planned. The Ministry of Finance will ensure that the mandatory provisions formed in line with the new NBR regulations will be tax deductible, effective as of January 1 , 
2003 (the respective NBR regulation and the concomitant government decision on the tax deductibility of provisions were approved as a prior action).

33. The NBR has adopted a new regulation introducing the "know-your-customer" principle, promoting high professional standards and fighting money laundering. The regulation incorporated comments received from commercial banks and the IMF's Monetary and Exchange Affairs Department.

34. We are committed to implementing the measures recommended in the safeguards assessment report. In line with the safeguards assessment report on the NBR, we will provide the Fund with information on improvements in the NBR's foreign reserve management function by the end of 2002, and submit, on a quarterly basis, reconciliations of NBR's accounting data with those reported to the Fund under the Stand-By Arrangement. We are also committed to making progress in implementing the other measures outlined in the safeguards assessment report.

\section{F. Governance Issues}

35. We are determined to improve the business climate and eliminate corruption. In particular, as agreed with the EU, we intend to ensure the operational independence of the anti-corruption agencies, provide sufficient resources for this purpose, and seek to improve their coordination. We will conduct all privatizations in an open and transparent manner. Public procurement will also be conducted in this manner, as spelled out in the ordinance on public procurement procedures. We will also review the existing regulation so as to strengthen the right to appeal against the award of public contracts. We will also intensify our efforts to prosecute individuals involved in financial wrongdoings, including FNI, Banca Romana de Scont, and other recent cases. 
Table 1. Romania: Quantitative Performance Criteria and Indicative Targets for 2001-02 y

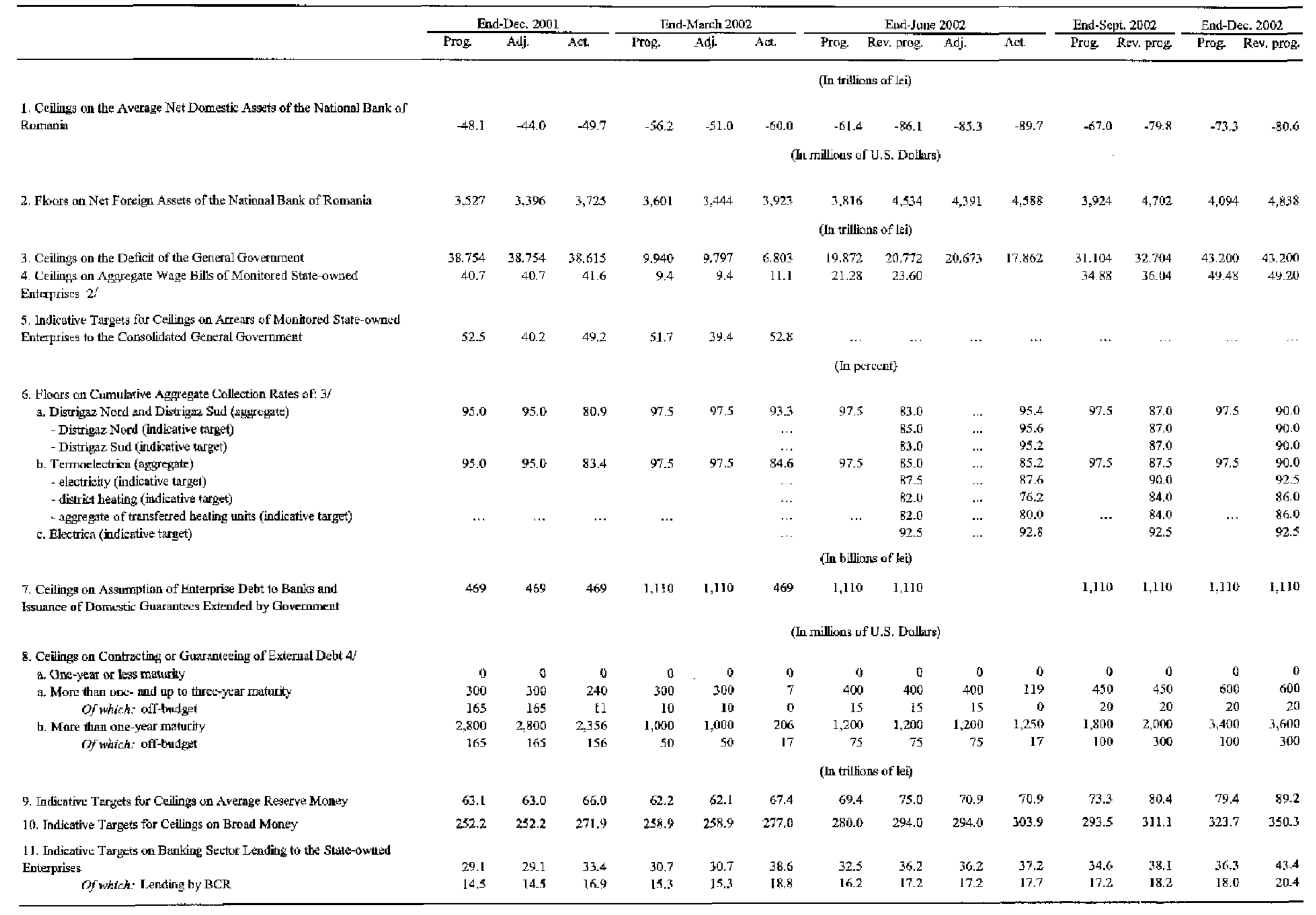

1/ The perfommane crituria and indicative targets envisaged under the program are defined in the Technical Memorandum of Understinding (TMU).

End-December 2001, end-March 2002, end-September 2002, and end-December 2002 figures are perfortance criteria, while end-June 2002 figures are indicalive targets. 2/ Adjusted to reflect the decrease in the pool of monitored compianies from 8.6 to 82 .

$3 /$ The definition of the collection rates was changed for lune 20102 and afterwards, as defined in the TMU.

4/ Nonaccumulation of external payments arrears of the government will be a perfocmance criterion monitored on a continuous basis. 
Table 2. Prior Actions, Structural Performance Criteria and Benchmarks

Status

\section{Prior Actions}

- Adoption of the following revenue measures:

(i) amendment of $E O 186 / 2001$ to eliminate the excise tax reduction for producers of cigarettes using domestic tobacco;

(ii) increases in excise taxes for gasoline and alcohol products and in the specific tax on beer as of May $1,2002(\emptyset 10)$; and

(iii) approval of the new VAT and profit tax laws in line with $q 11$.

- Issuance of a Government Decision on binding quarterly paths for the wage bill and employment reduction for the 82 monitored companies in line with $\$ 17$.

- Implementation of 4,200 layoffs (not externalization) in companies under the Ministry of Industry, and of the 750 layoffs in companies under APAPS as described in $\uparrow 17$ and $\$ 27$.

- Disconnection of energy supply to industrial users with the weakest payments records to utilities as described in 122 .

- Completion of the privatization of three companies with more than 1,000 employecs after February 1,2002 , as described in $\{26$.

- Selection of a privatization advisor for $\mathrm{BCR}$, as described in $\uparrow 28$.

Completed

- Signing of protocols on transfers of at least seven of Termoelectrica's heat-producing units to local municipalities, as described in $q 23$.

- Approval by the NBR of the regulation on bank provisions and, by the government, of a decision, specifying the taxation regime of those provisions, as provided for in the profit tax law, as described in 932 .

- Issuance of ministerial orders on blocking an amount equivalent to 4 percent of the wage bill target in Q3 of 2002 in the monitored companies under the respective ministries, as described in $¥ 18$.

\section{Structural Performance Criteria}

- Announcement of the invitation for expression of interest in BCR by end-February 2002, as described in $\mid 28$.

- Completion of the privatization of BCR by end-February 2003 as described in 128.

- Price adjustments in the energy sector, in line with the attached Table 3.

Continuous

- Approval of the budgets of the monitored state-owned companies for 2002 by end-2001.

Not observed; delayed completion in January 2002.

- Approval of the budgets of the monitored state-owned companies for 2003 by end-2002, in line with the govemment decision on quarterly ceilings for wage bills and employment, as described in I20. 
Table 2 (continued). Prior Actions, Structural Performance Criteria and Benchmarks

Status

\section{Structural Benchmarks}

- Issuance by the Authority for Privatization by end-April 2002 of a notification to the privatization advisors to increase the weight attached to the purchase price offered by the investor to at least 50 percent, as described in $\uparrow 25$.

- In addition to the five large companies privatized between January and June 2002, privatization of additional eight such companies by end-September 2002, as described in $\$ 26$.

- Amendment of law 326/2001 to:

(a) exempt elcetricity and gas distribution from the authority of local governments; and

(b) shorten, by mid-September 2002, the statutory periods to 15 days for payment and $\mathbf{4 5}$ days for disconnections, as described in q 23 .

- Announcement of a tender for the privatization of two electricity distribution comparies by midSeptember 2002, as described in $\lceil 24$.

- Sign the contract with a privatization advisor for Petrom by mid-October 2002.

- Transfer of another nine of Termoelectrica's heat-producing units to local municipalities by endJune 2002.

- All transferred units should no longer receive fuels at Termoelectrica's expense.

Completed

- Bringing into force by January 1,2003 the new regulations on loan classification and provisioning, as discussed in 932 .

- Refraining from the introduction of tax holidays or any other new distortionary tax incentives or

Continuous postponing the discontinuation of expiring ones, as discussed in $\| 11$.

- Receipt of binding bids from strategic investors for BCR by cnd-October in line with $\uparrow 28$. 
Table 3. The Authorities' Plan to Adjust Prices of Electricity, Heating and Natural Gas

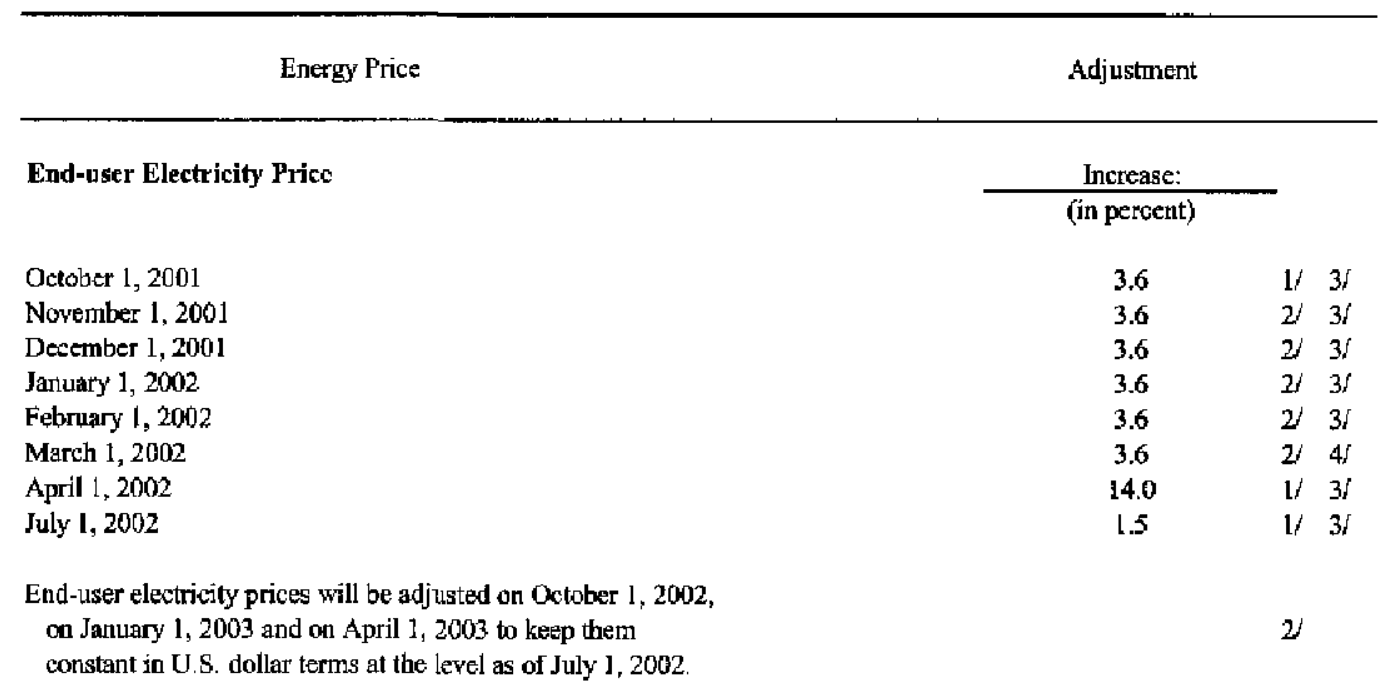

Electricity Producer Price for Termoelectrica

April 1, 2002

July $\mathrm{t}, 2002$

October 1, 2002

January 1,2003

April ], 2003

Heat Producer Price for Termoelectrica

October 1, 2001

Jаmиагу 1,2002

April ], 2002

July 1,2002

National Reference Price for Heating

January I, 2002

April 1, 2002

July 1, 2002

Unified End-nser Natural Gas Price

October 1, 2001

January 1, 2002

April 1, 2002

Juty 1,2002

October 1, 2002

January 1,2003

April 1, 2003
Adjust price to the equivalent of U.S, dollars

$\begin{array}{lll}39.00 & \text { l/ } & 3 f \\ 39.00 & \text { l/ } & 3 f \\ 39.00 & 2 / & \\ 39.00 & 1 / & \\ 39.00 & 1 / & \end{array}$

Adjust price to the equivalent of U.S. dollars

$\begin{array}{lll}15.00 & \text { l/ } & 3 / \\ 15.00 & \text { J } & 3 / \\ 15.00 & \text { I/ } & 3 J \\ 20.00 & \text { I/ } & 3 /\end{array}$

Adjust price to the equivalent of U.S. dollars

$\begin{array}{lll}15.40 & 2 / & 3 / \\ 15.40 & 1 / & 3 / \\ 20.00 & 1 / & 3 /\end{array}$

Adjust price to the equivalent of U.S. dollars

$\begin{array}{lll}82.50 & 1 / & 3 / \\ 82.50 & 1 / & 3 / \\ 82.50 & 1 / & 3 / \\ 82.50 & 1 / & 3 / \\ 82.50 & 2 / & \\ 90.00 & 1 / & 1 /\end{array}$

1/ Indicative target.

2/ Structural performance criteria.

3/ Implemented.

4/ Not observed. 


\section{TeChnical Memorandum of Understanding for Stand-By ARRangement}

1. Ceilings on the Average Net Domestic Assets of the National Bank of Romania

II. Targets for Floor on Net Foreign Assets of the National Bank of Romania

III. Ceilings on the Cumulative Deficit of the Consolidated General Government

IV. Ceilings on Aggregate Wage Bill of Monitored State-Owned Enterprises and Approval of the 2003 budgets of the Monitored State-Owned Enterprises

V. Indicative Target for Ceilings on Arrears of Monitored State-Owned Enterprises to the Consolidated General Government

VI. Floors on Cumulative Aggregate Collection Rates of Distrigaz Sud, Distrigaz Nord, and Termoelectrica

VII. Ceilings on the Assumption of Enterprise Debt to Banks by the Consolidated General Government and on the Issuance of Domestic Government Guarantees on Bank Lending to Enterprises

VIII. Ceilings on Contracting or Guaranteeing of External Debt

IX. Indicative Targets for Ceilings on Average Reserve Money

$\mathrm{X}$. Indicative Targets for Ceilings on Broad Money

XI. Indicative Targets for Ceilings on Banking Sector's Total Exposure to State-Owned Enterprises 


\section{Ceilings on the Average Net Domestic Assets of the National Bank of Romania}

The average net domestic assets of the National Bank of Romania (NBR) are defined as the difference between average reserve money (as defined in Section IX of this attachment) and average of net foreign assets (as defined in Section II of this attachment for the indicated month, excluding the adjustment for foreign currency denominated treasury bills), both expressed in local currency. Average net foreign asset stocks will be converted into lei for the purposes of calculating average net domestic assets at the average monthly lei/U.S. dollar rates specified in consultation with Fund staff. The average stock of NFA is defined as the average of the daily NFA as defined in Section II. The limits will be monitored from daily data on the accounts of the NBR supplied weekly to the IMF by the NBR. The average NDA as of September 2001 was lei 39,559 billion.

The ceiling on average net domestic assets of the NBR will be adjusted under the following circumstances:

(1) Downwards (upwards) in a proportional fashion, for the fraction of the month that gross foreign financing exceeds (falls short of) programmed levels, specified in Section II.

(2) For any change in reserve requirements as described in Section $I X$. Before undertaking any such changes, the NBR will consult IMF staff.

(3) Upwards (downwards) in a proportional fashion, by the lei equivalent of the decrease (increase) in the stock of foreign currency denominated Treasury bills (cumulative from end-September 2001).

(4) Downwards in a proportional fashion by the lei equivalent of the increase in foreign currency receipts from large privatizations (sale price above $\$ 10$ million) (cumulative from end-December 2001)

(5) Downwards by the shortfall in actual reserves from required reserves for any individual bank.

\section{Targets for Floor on Net Foreign Assets of the National Bank of Romania}

Net foreign assets of the NBR consist of reserve assets minus foreign liabilities. For the purposes of the program, reserve assets shall be defined as monetary gold, holdings of SDRs, any reserve position in the IMF, and holdings of foreign exchange in convertible currencies by the NBR. Excluded from gross reserves are long-term assets, NBR redeposits at the commercial banks, any assets in nonconvertible currencies, encumbered reserve assets, reserve assets pledged as collateral for foreign loans, reserve assets pledged through forward contracts, and precious metals other than gold. Monetary gold shall be valued at an accounting price of US $\$ 280.4$ per ounce and SDRs at US $\$ 1.355109$ per SDR. NFA stocks are measured at the last working day of the respective month. 
For the purposes of the program, foreign liabilities shall be defined as loan, deposit, swap (including any portion of the NBR gold that is collateralized), and forward liabilities of the NBR in convertible currencies including, foreign currency deposits of resident commercial banks at the NBR; IMF purchases; borrowing from international capital markets; and bridge loans from the BIS, foreign bavks, foreign governments, or other financial institutions, irrespective of their maturity.

All assets and liabilities denominated in convertible currencies, other than the U.S. dollar, shall be converted at their respective exchange rates against the U.S. dollar on December 31, 1999. All changes of definition or valuation of assets or liabilities as well as details of operations concerning sales, purchases, or swap operations of gold shall also be communicated to the IMF staff.

The NFA of the NBR will be adjusted:

(i) upwards/downwards by 100 percent of the excess/shortfall of gross foreign financing 1 from the programmed levels (on a cumulative basis from end-September 2001).

$\begin{array}{ll}\text { December } 2001 & \text { US\$248 million } \\ \text { March } 2002 & \text { US } \$ 248 \text { million } \\ \text { June } 2002 & \text { US\$953 million } \\ \text { September } 2002 & \text { US\$953 million } \\ \text { December } 2002 & \text { US\$953 million }\end{array}$

(ii) by the change in the stock of foreign currency denominated Ministry of Finance Treasury Bills including those issued for bank restrueturing (on a cumulative basis from endSeptember 2001). The outstanding stock on September 30, 2001 was $\$ 423.7$ million evaluated at the program exchange rates.

(iii) upwards by the amount of foreign currency receipts from large privatizations (sale price above $\$ 10$ million) (cumulative from end-December 2001).

The NFA will be monitored on the basis of daily operational data through to end-March 2002, after which monetary survey data will be used. Daily data will still be used to calculate average NFA. All data is provided by the NBR. The NFA on September 30, 2001 was US\$3,311 million.

\footnotetext{
${ }^{1}$ Foreign financing is defined as disbursements of balance of payments support loans to the government with a maturity of more than a year from multilateral and bilateral creditors and resources with a maturity of more than one year raised in the international capital markets by the government. This excludes use of IMF resources.
} 


\section{Ceilings on the Cumulative Deficit of the Consolidated General Government}

The consolidated general government includes the state budget; the budgets of the local authorities; the social protection funds; ${ }^{2}$ the "Special Fund for Modernizing Roads", the "Special Fund for the Development of the Energetic System", the "Special Reinsurance Fund", the "Authority for Privatization" (APAPS), the "Fund for the Development of Romanian Agriculture", other extra-budgetary funds managed by the Ministry of Finance or other Ministries and agencies outside the budgetary framework; other extra-budgetary operations of ministries financed by foreign loans; and the counterpart funds created from the proceeds of foreign loans. Any new funds created during the program period to undertake operations of a fiscal nature as defined in the IMF's Manual on Government Finance Statistics will be incorporated within the definition of consolidated general government.

Under the program, the deficit of the consolidated general government will be measured based on revenue and expenditure data provided by the Ministry of Finance, and also based on "below the line" data, that is, by the sum of domestic and external financing of the budget as well as privatization proceeds received by all entities of the consolidated general government and proceeds from the recovery of bank asset by AVAB. All efforts will be made to reconcile the measurement of the deficit from "below" and from "above the line". However, should these efforts not succeed in eliminating the discrepancies, the respectively higher deficit number will be used for program purposes.

For program purposes, net credit of the banking system to the consolidated general government is defined as all claims of the banking system on the consolidated general government less all deposits of the consolidated general government with the banking system. Foreign-currency denominated credit to government outstanding at December 31, 2001 will be converted in U.S. dollars at the end-December 1999 exchange rate and from dollars into lei using the rates specified in consultation with Fund staff. Foreign-currency denominated credit newly issued in 2001 and 2002 will be valued at the exchange rates specified in consultation with Fund staff. Government loans to banks at an interest rate less than the reference rate of the NBR to finance on lending to economic agents are excluded from government deposits; an agreed listing of the accounts to be treated as government deposits for program purposes is contained in the FAD aide memoire "Romania: Measuring the Fiseal Deficit", Part I, Appendix 11, February 1994.

For program purposes, the ceilings on the quarterly cumulative deficit of the consolidated general government in 2002 will be adjusted downwards by a shortfall of the cumulative quarterly privatization proceeds received by the consolidated general government. Privatization receipts denominated in foreign currency will be converted into U.S. dollars using the exchange rates on December 31, 1999, and from dollars into lei using the rates specified in consultation with Fund staff. The floor for these proceeds is as follows:

\footnotetext{
${ }^{2}$ These include the State Social Security Fund, the Unemployment Fund, and the Health Social Insurance Fund.
} 
Actual

\section{(In billions of lei)}

Cumulative quarterly privatization proceeds of the general consolidated Government for 2002:

March 31, 2002 (minimum target)

June 30, 2002 (minimum target)

September 30, 2002 (minimum target)

December 31, 2002 (ninimum target)
1,000

2,000

3,000

4,000
856.7

$1,901.5$

As a contingency measure to achieve the deficit target of lei 43,200 billion in 2002 , the government ordinance on the first budget rectification in 2002 will include a stipulation according to which lei 2 trillion of the expenditure entitlements of the special fund for roads will be blocked. The blocked expenditure can be released at the earliest as of November 1, 2002, provided that the end-September revenue target has been met. The revenue target refers to the estimate of total cumulative revenue agreed between the Ministry of Public Finance and IMF staff for the general consolidated budget for the first three quarters of 2001 (see below).

Consolidated general government

(In billions of lei)

(cumulative total revenues including grants)

June 30, 2002 (actual) 205,695

July 31,2002 (indicative revenue target) 245,766

August 31, 2002 (indicative revenue target) 285,914

September 30, 2002 (binding revenue target) $\quad 328,037$ 


\section{Ceiling on Aggregate Wage Bill of Monitored State-Owned Enterprises and Approval of the 2003 Budgets of the Monitored State-Owned Enterprises}

\section{A. Ceiling on Aggregate Wage Bill of Monitored State-Owned Enterprises.}

The set of 82 monitorcd state-owned enterprises, whose wages are to be monitored under Emergency Ordinance 79/2001, is specified in Government Decision 866/2001. The wage bill of this set of state-owned enterprises has been adjusted for the decrease in the number of enterprises from 86 in 2001.

The wage bill will be adjusted as follows:

(i) downwards by the amount of savings due to "externalization" (defined as the spinning off of a unit or its transfer to another entity) in excess of lei 400 billion ( 1 percent of the 2001 targeted wage bill of the 82 companies, distributed proportionally among the four quarters of 2002). In each month, savings from externalization will be calculated on a company by company basis as the product of the number of externalized employees so far and the company's average wage.

(ii) if a company is privatized, downwards by the budgeted wage bill of the privatized company.

(iii) if a company is cxcluded from the list after not having registered losses or arrears for three consecutive years, downwards by the budgeted wage bill of the excluded company.

The wage bills will be measured on a cumulative basis across the different sectors, on a monthly basis. The Ministry of Labor and Social Protection will undertake the responsibility of collecting data from the various line ministries (RAs and national companies) and APAPS (commercial companies), and will report the wage bills and employment figures for each of the monitored enterprises (including aggregate figures for each ministry and for the overall total) to the IMF on a monthly basis. Employment reduction resulting from all forms of outsourcing will be reported in the "externalization" column of the respective tables, with a footnote, if necessary.

\section{B. Approval of the 2003 Budgets of the Monitored State-Owned Enterprises.}

The structural performance criterion on the approval of the 2003 budgets of the monitored state-owned enterprises (see paragraph 20 of the SMEFP and Table 2) refers to the set of companies specified under Emergency Ordinance 79/2001, which continue to be state-owned as of December 15, 2002. 


\section{Indicative Target for Ceilings on Arrears of Monitored State-owned Enterprises to the Consolidated General Government}

The ceiling applies to the outstanding stock of arrears of the set of 82 monitored state-owned enterprises, whose arrears are to be monitored under Emergency Ordinance 79/2001 and Government Decision 866/2001. Under the ordinance, arrears are defined as accounts payable past the due date stipulated explicitly in the contracts, or if no such explicit date exist, 30 days after services/products are provided. The reporting on total arrears will have the following subcategories: to the state budget, to the social security budget; to the local budget; to special funds; and to other creditors. Arrears to the consolidated general government are defined as the sum of the first four categories. Amounts reflecting tax arrears exclusive of penalties will be reported separately. For arrears which have been rescheduled/canceled, the rescheduled/canceled amounts (including penalties) will not be counted as arrears reduction, and has to be reported. The report will include a breakdown of arrears to the ten largest creditors for each company. The report will also include data on overdue claims of each of the monitored companies, as reported under Emergency Ordinance $79 / 2001$. For changes to the set of monitored companies, the targets will be adjusted downwards/upwards by the amount of arrears of the companies removed/added to the set. Data for monitoring purposes shall be supplied monthly to the IMF by the Ministry of Finance. The stock of arrears at end-December 2000 was lei 47.2 trillion.

\section{Floors on Cumulative Aggregate Collection Rates of Distrigaz Sud, Distrigaz Nord, and Termoelectrica}

Floors will be set on the cumulative collection rates of the following companies: the combined rate (performance criterion) of Distrigaz Nord and Distrigaz Sud (indicative targets on the individual company collection rates); on Termoelectrica's (including the production units transferred to local authorities) combined collection rate (performance criterion) for both heating and electricity (indicative targets on the separate collection rates); on Electrica's collection rate (indicative target); and on the aggregate collection rate of the Termoelectrica production units transferred to local authorities (indicative target). The floors and outcomes for end-September, end-December 2001, and end-March 2002 are measured using cumulative collection rates defined as the ratio of collections to billings, measured from the start of the year to the specified date. For the remaining test dates floors on collection rates are defined as follows:

(i) Termoelectrica and local authority units (Heating sector), Distrigaz Nord and Sud: Heating and gas bills are lagged by one month. Definition of 12-month moving collection rate $c(m)$ for the month $m=1,2.12$ :

$$
\begin{aligned}
\mathrm{c}(\mathrm{m})= & \text { sum(heating collections }(\mathrm{m}) \text {; heating collections }(\mathrm{m}-12) \text { divided by } \\
& \text { sum(heating bills }(\mathrm{m}-1) \text { :heating bills }(\mathrm{m}-13)) .
\end{aligned}
$$

(ii) Termoelectrica and local authority units (Electricity sector); Electrica; Definition of

12-month moving collection rate $c(m)$ for the month $m=1,2.12$ :

$\mathrm{c}(\mathrm{m})=$ sum(electricity collections(m):electricity collections $(\mathrm{m}-12)$ divided by sum(electricity bills $(\mathrm{m})$ : electricity bills $(\mathrm{m}-12)$ ). 
Using these definitions the collection rate of Termoelectrica at end-December 2001 was 85.5 , and of the two gas companies, 85.5.

Data for these companies will be collected by the Ministry of Industry and reported to the IMF on a monthly basis. The Ministry of Industry will include in this report data on billings and collections registered by Distrigaz Nord, Distrigaz Sud, Electrica and Termoelectrica, as well as information on possible dis- and reconnections for the following industrial (a) and heating (b) companies.

a) SC Siderurgica, COS Targoviste, Minvest SM-Rosia Poieni, Moldomin, Minvest-SM, Balan, Snif, SC Industria Sarmei, Gavazzi Steel, Minvest-SM Baia de Aries, SC Turnu, CUG Cluj, SC Apaterm Galati, SC Tractorul UTB, SC Chimcomplex, Minvest- SM Brad, Apa Nova (RGAB), Minvest -SM Coranda Certej, Minvest -SM Poiana Rusca Teliuc, Siderca, SC Electrocarbon, Nitramonia, Viromet, Amonil, Oltchim, Sere Codlea, US Govora, Republica, Zahar Bod, Stirom Bucuresti, Danubiana, Gerom Buzau, Colorom Codlea, Roman Brasov, Metrom Brasov, Carfil Brasov, Stiaz Azuga, Faur Bucuresti, UPSOM SA Ocna Mureş, Bicapa SA Târnăveni, SC Ind.Sârmei C.Turzii, SC Stipo SA Dorohoi, Ampellum SA Zlatna, SC Cugir SA, SC Melana Săvineşti, Letea Bacau, Rafo SA Oneşti, SC Fortus SA laşi, Ambro SA Suceava, Stratusmob SA Blaj, SC Sticla Turda, Iris SA Cluj, Metalurgica Aiud.

b) Radet Bucuresti,Radet Constanta, Apaterm Galati, RA Termoficare Craiova, SC Apaterm, SA Deva, Termica SA Targoviste, Termoficare Petrosani, Dalkia Ploiesti, SC Termoficare Petrosani, SC Universal Lupeni, Aptercol Braila, SC Citadin Aninoasa, RA Termoficare Cluj, SC Aqua Calor P. Neamt, RA Energornur Tg Mures, SC Energ. Temica Sibiu, Termoloc Populatie Bacau, RA Goscom Roman, Proditerm Bistrita, Rail Hunedoara, Comunala RA Satu Mare, Termica SA Botosani, Radet Bucuresti, Enet Focsani, Cet Braila, Cet Govora, RA Termo Craiova, Ram Buzau, RA Termo Brasov, Aquaterm Tg. Jiu, Aquaterm 98 Pitesti.

\section{Ceilings on the Assumption of Enterprise Debt to Banks by the Consolidated General Government and on the Issuance of Domestic Government Guarantees on Bank Lending to Enterprises}

The ceilings apply to the cumulative stock from end-September 2001 of newly guaranteed or assumed domestic debt by the consolidated general government. For program purposes, the assumption of enterprise debt to banks by the consolidated general government and the issuing of a guarantee to assume enterprise debt to banks are treated as being equivalent. This limit includes any loan on which the government pays or guarantees interest, even if the principal is not guaranteed. The consolidated general govemment is defined in Section III of this attachment. The criterion also applies to the use of APAPS resources for recapitalizing enterprises or as collateral for bark loans. Foreign currency denominated loans will be converted at accounting exchange rates specified in consultation with Fund staff. These limits exclude: 
- the contracting or guaranteeing of external debt, for which separate limits are set out in Section VIII of this attachment;

- debt transferred in the process of bank restructuring, privatization or liquidation of stateowned enterprises.

- the assumption of debt as a result of an activation of a guarantee or collateral.

- domestic guarantees for loans for fuel imports for the 16 heat-producing units which were transferred from Termoelectrica to local authorities, to the extent that external off-budget guarantees issued for this purpose (see Section VII) fall short of US $\$ 120$ million (i.e., the sum of domestic and external guarantees issued for this purpose must not exceed US\$120 million).

Data for monitoring purposes shall be supplied monthly to the IMF by the Ministry of Finance. The stock of guarantees and debt assumed as described in this section was lei 469 billion as of end-September 2001.

\section{Ceilings on Contracting or Guaranteeing of External Debt}

The ceilings apply to the cumulative stock for each year of newly contracted or guaranteed external debt by the consolidated general government. The consolidated general government is defined in Section III of this attachment. This performance criterion applies not only to debt as defined in point No. 9 of the IMF Guidelines on Performance Criteria with Respect to Foreign debt adopted on August 24, 2000 (Executive Board Decision No. 12274-(00/85)) but also to commitments contracted or guaranteed for which value has not been received. The ceilings also apply to any assumption of loans for debt outstanding which were not previously contracted or guaranteed by the consolidated general government. Excluded from the ceilings are liabilities to the IMF and bridge loans from the BIS, foreign banks, foreign governments, or any other financial institution. Debt falling within the ceilings shall be valued in U.S. dollars at the exchange rate prevailing at the time the contract or guarantee becomes effective. Loans considered concessional are also excluded from the ceilings. Offbudget debt includes all debt to non-budget entities from private sector creditors guaranteed by the Ministry of Finance. Loans for fuel imports for Distrigaz, Termoelectrica, and the 16 heat-producing units which were transferred from Termoelectrica to local authorities are included in the overall ceilings, while being excluded from the off-budget guaranteed debt ceilings. With respect to new loans contracted to ensure fuel imports for the heating period 2002/2003, they are excluded from the off-budget guaranteed debt ceilings up to an amount of US\$200 million for Termoelectrica and US\$120 million for the transferred heating units. Fuel import loans contracted by Termoelectrica and the transferred heating units are excluded from the ceilings on debt with maturities between one and three years.

Concessional loans are defined as those with a grant element of at least 35 percent of the value of the loan, using currency-specific discount rates based on the commercial interest reference rates reported by the OECD (CIRRS) in effect at the time of contracting or guaranteeing the loan. 
The ceilings shall be monitored from data supplied monthly to the IMF by the Ministry of Finance. The stock of debt at end-June 2001 was $\$ 1,194$ million for maturities over one year ( $\$ 83$ million of which was off-budget), $\$ 196$ million for the subceiling of debt with maturity of one to three years (none of which was off-budget), zero for debt with less than one year maturity.

Nonaccumulation of external payments arrears of the government will be a performance criterion monitorcd on a continuous basis. For program purposes, arrears with respect to called-up sovereign loan guarantocs are defined as external payments overdue more than 30 days.

\section{Indicative Targets for Ceilings on Average Reserve Money}

Average reserve money is defined as the sum of average currency in circulation outside the NBR and average deposits (required plus excess reserves) of the commercial banks at the NBR for the indicated month. Commercial bank deposits exclude required and excess reserves in foreign exchange for foreign exchange deposits. Data on reserve money will be monitored from the daily indicators data of the NBR, which shall be supplied to the IMF weekly by the NBR. The stock of average reserve money as of September 2001 was lei 60,442 billion.

The ceilings on average reserve money will be adjusted in the following circumstances:

(1) Should reserve requirements be increased/decreased from 25 percent on all required reserves held in lei, the reserve moncy targets would be increased/decreased by the product of the change in the reserve requirements and the programmed deposits for which required reserves are held in lei. The level of the programmed deposits is lei 134,285 billion for June 2002, lei 142,014 billion for September 2002 and lei 171,352 billion for December 2002.

(2) The reserve money targets will be lowered by the shortfall in actual reserves from required reserves for any individual bank.

\section{Indicative Targets for Ceilings on Broad Money}

Broad money is defined as the liabilities of the banking system with the non-bank public. Broad money includes foreign currency deposits of residents, but excludes govemment deposits and deposits of foreign monetary institutions and other non-residents. For the purposes of the program, deposits which are denominated in foreign currency will be converted into lei at the accounting exchange rates specified in consultation with Fund staff.

Data on broad moncy will be monitored from the monthly data on the accounts of the banks and the banking system, which shall be supplied to the IMF monthly by the NBR. The stock of broad money at program cxchange rates as of September 30,2001 was lei 235,363 billion. 


\section{Indicative Targets for Ceilings on Banking Sector's Total Exposure to State- Owned Enterprises}

Total exposure covers all loans, advances, holdings of debt and off-balance sheet exposure of resident banks to state-owned enterprises. Data on loans will also be reported separately from total exposure. State-owned enterprises are all regis autonomes and commercial companies with majority ownership by the government or APAPS. For the purposes of monitoring, foreign currency denominated debt will be converted in lei at end-month lei/dollar exchange rates specified in consultation with Fund staff. Foreign currency denominated credit in convertible currencies, other than the U.S. dollar, shall be converted at their respective exchange rates against the U.S. dollar as specified in Section II of this attachment. Data on banking sector lending to state-owned enterprises will be monitored from monthly data provided by the NBR.

The amount of total exposure, as reported by the NBR, will include (on a cumulative basis from end-March 2002):

(i) exposure to companies where the majority ownership shifted to the private sector. For this purpose, APAPS and the relevant ministries will provide a monthly update of their portfolio to the NBR;

(ii) any amount of debt or off-balance sheet write-offs;

(iii) any assumption of debt or off-balance sheet items by the government or other public bodies.

Additionally, the NBR will report monthly on total exposure of the banking system to stateowned enterprises with outstanding exposure over lei 100 billion, on a company-by-company basis. The stock of banking sector exposure to state-owned enterprises at program exchange rates as of September 30,2001 was lei 27,052 billion of which lei 13,541 billion was to BCR. 


\section{Statement by the IMF Staff Representative \\ August 28, 2002}

This statement provides information that has become available since the issuance of the staff report for the first and second reviews under the Stand-By Arrangement and request for waiver and modification of performance criterion for Romania (EBS/02/150). The statement does not change the appraisal in the staff report.

The July inflation outcome was favorable, with the 12-month inflation rate falling to 23 percent (19.3 percent for CPI excluding administered prices). The end-year inflation is thus very likely to be lower than the program target of 22 percent and could even fall below the authorities' revised forecast of 21 percent. Indicators for the second quarter of 2002 show a continuing pick-up in economic activity, with industrial production rising by 4.1 percent relative to the same period of 2001, and exports increasing by 17.5 percent, in U.S. dollar terms. The current account deficit for the first half of 2002 was 2.0 percent of projected annual GDP, somewhat higher than estimated in the staff report, owing to lower transfer receipts and somewhat higher dividend payments. The staff believes that these deviations are transitory and that there is no need to revise the annual program target of 5.1 percent of GDP.

As of August 18, gross foreign reserves of the National Bank of Romania (NBR) totaled US $\$ 6.3$ billion ( 3.9 months of prospective annual imports), compared with US $\$ 4.9$ billion at end-2001. The expansion of credit to the nongovernment sector slowed somewhat in July, to about 28 percent in real terms, inter alia reflecting the effects of enhanced supervision.

The June indicative targets on the ceiling on the issuance of domestic guarantees and assumption of enterprise debt to banks by the government was met. The target on the overall wage bill of the monitored group of state-owned companies was exceeded by 2.1 percent, as projected in the staff report, despite reducing employment by about $3 / 4$ percent more than envisaged under the program. On the structural side, the authorities have privatized two large companies since end-June and expect to sell another five such companies by end-September. 


\section{N T E R N A T I O NAL M O NETARY FUND}

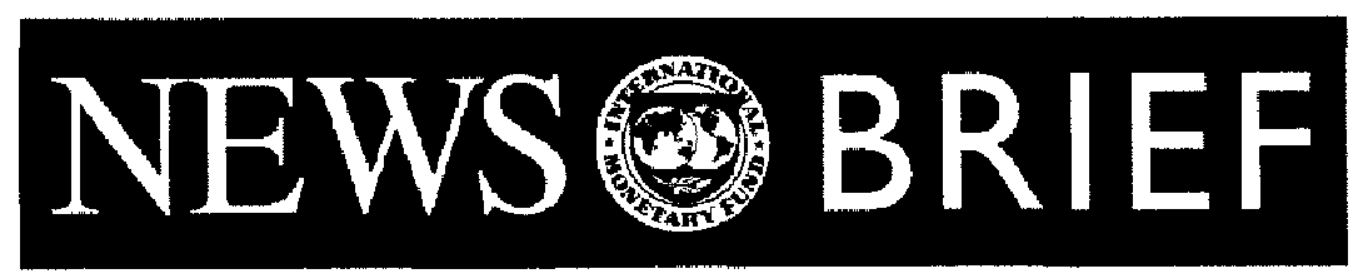

FOR IMMEDIATE RELEASE

News Brief No. 02/91

FOR IMMEDIATE RELEASE

August 28, 2002
International Monetary Fund

700 19th Street, NW

Washington, D. C. 20431 USA

\section{IMF Approves US\$109 Million Credit Tranche Under Stand-By Arrangement to Romania}

The Executive Board of the International Monetary Fund (IMF) today completed the first and second reviews of Romania's economic performance under the Stand-By Arrangement. The decision will enable Romania to draw SDR 82.67 million (about US\$109 million) from the IMF immediately.

The 18-month Stand-By Arrangement for SDR 300 million (about US $\$ 396$ million) was approved on October 31, 2001 (see Press Release No. 01/43). So far, Romania has drawn SDR 52 million (about US $\$ 69$ million) from the IMF.

Following the Executive Board discussion, Eduardo Aninat, Deputy Managing Director and Acting Chair, said:

"Romania has achieved favorable macroeconomic performance under its program - including a higher rate of growth, supported by a recovery in agriculture and exports; progress in reducing inflation and the budget and current account deficits; and a build-up in official reserves and improved access to international financial markets. However, success in restraining wages and reducing losses in public enterprises, particularly in the energy sector, has been mixed.

"In completing the first and second reviews of the program, Executive Directors therefore underscored the critical importance of swiftly and fully implementing the measures to correct weaknesses in these areas and, in particular, moving ahead decisively with the remaining structural reform 
agenda. This will be essential in order to achieve durable growth and macroeconomic stability, and to strengthen the momentum of transition to a well-functioning market economy, paving the way for EU accession.

"The authorities' strategy to reduce inflation will be supported by containing the budget deficit to below 3 percent of GDP in 2002 and by a further tightening in 2003. The recently passed VAT and profit tax laws will improve the structure of the tax system and the business climate. Going forward, it will be important to further lower subsidies, while improving well-targeted social protection, and to refrain from granting ad hoc tax incentives.

"A crucial component of the program continues to be a reduction in the quasi-fiscal deficit of state-owned enterprises. The implementation of the government's wage and employment programs for 2002 and 2003 will be of key importance both for improving enterprise profitability and for the success of the disinflation strategy. In this context, the authorities will need to make every possible effort to contain the impact of the decision to substantially raise the minimum wage in 2003 on overall wage trends in public enterprises-and to stand ready to implement prompt corrective measures if necessary. In the energy sector, after appropriately ambitious adjustments in prices in 2001 and 2002, priority should now be given to correcting the persisting weakness in the collections of the main utilities.

"Monetary policy, implemented in the framework of a managed floating exchange rate regime, will aim at further reducing inflation, while preventing an unwarranted real appreciation of the currency. The authorities have taken welcome measures to closely monitor and contain the rapid expansion of foreign currency denominated credit.

"The government is committed to reinvigorate the privatization process and will move ahead with several major privatization projects. Particularly important is the privatization of the largest state-owned bank, BCR, which will involve the complete sale of the state's capital share and transfer of control to a strategic investor. Privatization in the gas and electricity sectors is set to accelerate. Together with restructuring measures, this will be essential to improve the efficiency of collections and ensure the energy sector's financial soundness, which is key for sustained macroeconomic stability and growth," Mr. Aninat said. 


\section{Statement by J. de Beaufort Wijnholds, Executive Director for Romania August 28, 2002}

As usual, the staff report presents a candid and fair assessment of recent economic developments. The Romanian authorities wish to express their appreciation for the continued policy dialogue and advice aimed at consolidation of macroeconomic stability.

From its inception, the program has required consistent, comprehensive and frontloaded measures. Reflecting the determined implementation by the authorities of the policy measures, the macroeconomic performance has been fully in line with program targets. All the prior actions and additional measures for correcting the slippages on some structural areas were observed by mid-August 2002. At the same time, Romania has made substantial progress towards its goal of EU accession. By August 2002 the country provisionally closed 14 negotiating chapters out of 27 officially opened, aiming at catching up with the other candidate countries for EU accession. Despite the encouraging macroeconomic achievements, the authorities are fully aware of the remaining weaknesses and the challenging reform agenda, mainly in areas of restructuring and privatization.

\section{Recent developments and outlook}

Since the approval of the Fund-supported program in October 2001, macroeconomic conditions have continued to improve, in line with the program targets. After a strong GDP growth of 5.3 percent in 2001, one of the highest in the region, growth in 2002 is estimated at 4-4.5 percent, due to a lower contribution of agriculture and some impact of the slowdown in demand of Romania's trading partners. A growth rate close to 5 percent could be reached again starting in 2003 , in line with the strengthening of economic activity, mainly in Europe. The 12-month headline inflation rate fell to 23 percent in July 2002, in spite of continuing adjustment in energy prices, and it might fall below the end-December program target of 22 percent. The disinflation efforts will be continued and a 15 percent target is considered for next year. The current account deficit was contained below 6 percent in 2001 and the authorities intention is to keep it at 5 percent of GDP in 2002, which is fully achievable having in view the favorable developments for the first half of the year. The increase in international reserves was significantly stronger than initially estimated under the program and the 2002 end-December target for the reserves level in terms of import coverage has already been reached. Romania's position on the international capital markets has continued to become stronger and a 10-year euro bond issue was successfully concluded in May 2002. The good performance on the macroeconomic front and in implementing further market-oriented reforms has let both Standard \& Poor's and Fitch to upgrade again Romania's sovereign risk in April and June, respectively.

\section{Fiscal policy}

The Romanian authorities are fully committed to continue the fiscal consolidation and to meet the 2.9 percent fiscal target for 2002 , being ready to avoid any slippages from 
these goals. Due to a weaker than expected revenue performance and the downward revision of estimated GDP growth the government decided to eliminate excise reductions for cigarette producers using domestic tobacco as well as to increase excise taxes for gasoline and alcohol products, in order to offset the revenue shortfall. In the same vein, the government intends to broaden the tax base of the pension and unemployment funds. The reform of the tax system has continued and new VAT and profit tax law were approved recently, the main objectives of which are to enforce elimination of tax exemptions and holidays as well as any distortionary tax incentives. Nevertheless, corrective measures on the expenditure side to offset the revenue shortfall have been taken and a prudent supplementary budget was approved in July in close consultation with Fund staff. The authorities are carefully monitoring expenditure developments and stand ready to identify additional steps, if the fiscal target is put in danger. Tax administration reform has been initiated in line with the recommendations of the Fiscal Affairs Department technical assistance missions. A Government Decision has already been drafted for setting up a unified tax administration department within the Ministry of Public Finance and a large taxpayer directorate in Bucharest. It is expected that the Cabinet will approve this decision soon.

Consistent with the fiscal consolidation commitment and to continue the disinflation efforts and containing the current account deficit, the Romanian authorities have already agreed with the Fund to reduce the general consolidated budget deficit to 2.65 percent of GDP in 2003. In this respect the draft of 2003 budget, which is under preparation, has already taken into consideration significant decisions, such as limiting the annual average increase of net wage bill in the budgetary sector to 3 percent in real terms, incorporating other special funds within the state budget, refraining from any other tax cuts. A social program for 2002-2003 was approved in late July in order to soften the impact of higher utility prices on low-income categories of the population and to further improve the social safety net.

\section{Wage Policy}

In order to ensure public sector wage discipline, which was one of the main weaknesses of the past programs, by the end of 2001 the authorities had approved almost all the 2002 budgets of state-owned companies and regies autonomes. Unfortunately, higher than expected wage increases in the third quarter of 2001 moved this burden to the next quarters. Additional measures proved to be insufficient to offset this trend and the end-December 2001 and end March 2002 targets for the wage bill of state companies were missed. To improve the wage control mechanism quarterly ceilings for wage bills and employment were approved for the 82 monitored companies and bonus payments were further limited. At the same time, in the last months employment reduction in these companies have been accelerated, the net reductions during January-June reaching 12,900 positions (excluding outsourcing), out of which 8,300 layoffs, meeting the prior action.

In June, a convention was concluded with two large trade unions regarding the minimum wage hike and other social measures, starting with January 1, 2003. The authorities 
are confident that this agreement should ensure the necessary social stability for further implementation of all measures under the economic program. At the same time it could reduce tax evasion and offset the effects of large energy price adjustments on low-income population. The recent Fund mission, which visited Bucharest early July, reviewed the impact of this convention on 2002-2003 macroeconomic targets and the authorities agreed upon measures to reduce its risk to the program. Also the authorities expressed their strong commitment not to increase again the minimum wage during 2003 and not to index it either to CPI or foreign currencies. At the same time, the Government is confident that the collective contracts at enterprise level, signed in May for one year, no longer include automatic adjustments in the wage scale linked to the higher minimum wage.

\section{Energy Sector and Privatization}

Since the Board discussion last year several measures were implemented for improving the energy sector: significant energy price adjustments to cost-efficiency levels in line with the agreed time table, disconnections to the largest non-payers, and transfer of Termoelectrica's heat producing units to local municipalities. As a result, in June and July collection rates were slightly higher than in previous months. For a better monitoring of daily cash collections, the established system of escrow accounts will be continued and monitored by the Ministry of Public Finance. The authorities have agreed to accelerate competition within the sector by expressing the intention to open it to the private sector, starting preparation for full privatization of 2 electricity and 2 gas distribution companies. After successful privatization of Sidex - a steel mill with more than 27,000 employees - the oil company Petrom, the largest enterprise in state portfolio is prepared for privatization and could be considered another milestone in the country's program. The short list for selection of a privatization advisor has been published and the Government has expressed its determination to approve the privatization strategy by end-December 2002 .

The authorities are giving due consideration to acceleration of the privatization process. To speed up the privatization and increase the attractiveness of the Romanian companies, a new law was passed in April which allows partial or full write-off of outstanding debts to the budget for companies which are ready to be privatized and other steps have been taken into consideration, as mentioned in the SMEFP, which could facilitate progress in this area. Following the 5 large companies privatized in the first half of the year, privatization was concluded for 2 others in July and additional 10 are under different stages of negotiations (five of them are expected to be privatized by end-September). The performance in this area is a steady concern of the authorities. They are also confident that the approval of the World Bank's PSAL II program will support Romania's efforts to further restructuring and privatization.

\section{Monetary policy}

Inflation has been monitored carefully as a central objective of the economic program. During 2001-2002 (August) prudent monetary policy together with fiscal 
consolidation have moderated inflationary demand pressures, bringing inflationary expectations on a downward trend. The success of reducing inflation has strengthened the authorities' credibility and built up a sound basis for a further successful disinflation process. The inflation rate is projected to decrease further (according with Romania's Medium term Economic strategy submitted to the European Commission) down to one digit by 2004 . An acceleration of structural adjustment in the real sector, a stronger financial discipline and improved corporate governance as well as a wage policy consistent with macroeconomic developments will support this process. The declining trend of inflation and stronger demand for lei assets has allowed the NBR to gradually reduce interest rates. The most recent data shows that the average interest rate for sterilization operations declined to 25.9 percent and the NBR's 3 month-deposit rate has been lowered by 3 percentage points to 25 percent. Since August 20, the central bank reduced also the yield on deposit and credit facilities extended to commercial banks to 5 percent and 45 percent respectively. At the same time, the average 3 -month T-bill rate declined in July-August by 2.6 percentage points.

The NBR continues to conduct monetary policy in the framework of a managed float and to monitor the exchange rate against a euro/dollar basket. The euro is expected to become the reference currency for the leu exchange rate during 2003-2004. A gradual monthly real appreciation of the currency remains the intention within the target, supporting disinflation and the NBR has reduced the frequency of its interventions on the foreign exchange market. The minimum reserve requirements rate on the lei deposits has been lowered again to 22 percent, while the foreign exchange one was set at the same level. Furthermore, lower inflation and tamed inflationary expectations have allowed the NBR to increase the maturity of its sterilization instruments.

A further strengthening of supervisory capacity of the NBR has been and still is one of the main objectives. To reach this goal the central bank steadily implemented measures aimed at increasing competitiveness and stability as well as developing banks' capacity to ensure an efficient financial intermediation. The new regulations approved recently regarding the reserve requirements and loan provisioning is fully in line with international best practices. At the same time, the central bank is ready to act further to reduce any risks related to development of foreign currency denomination lending.

The share of state-owned banks in total capital and total assets has decreased over the past few years and with the privatization of BCR, the largest commercial bank, by early 2003, the process is entering in its final stage. Preparations for privatizing BCR are under way. The privatization advisor has been appointed and short list has been finalized. The authorities expressed their intention to sell the majority stake to a foreign strategic investor.

The Romanian authorities consider that an in-depth assessment of the financial sector at this time would help to identify its strengths, risks and weaknesses. In this vein, in order to strengthen the financial sector stability and soundness and to avoid any disturbances, the Romanian authorities expressed in April this year the interest to participate in the IMF/World Bank Financial Sector Assessment Program (FSAP). 
The Romanian policy in combating money laundering and financing of terrorism is strongly linked to international efforts in this area. The authorities in coordination with international bodies are working on further legal amendments with the view to bring Romania in full compliance with UN and EU recommendations.

In view of the above I wish to ask for Directors' support for the completion of the first and second reviews, request for waiver and modification of the performance criterion. I would also want to convey the Romanian authorities' strong commitment to continue the reform process, leading to a sound and sustainable economic development. 